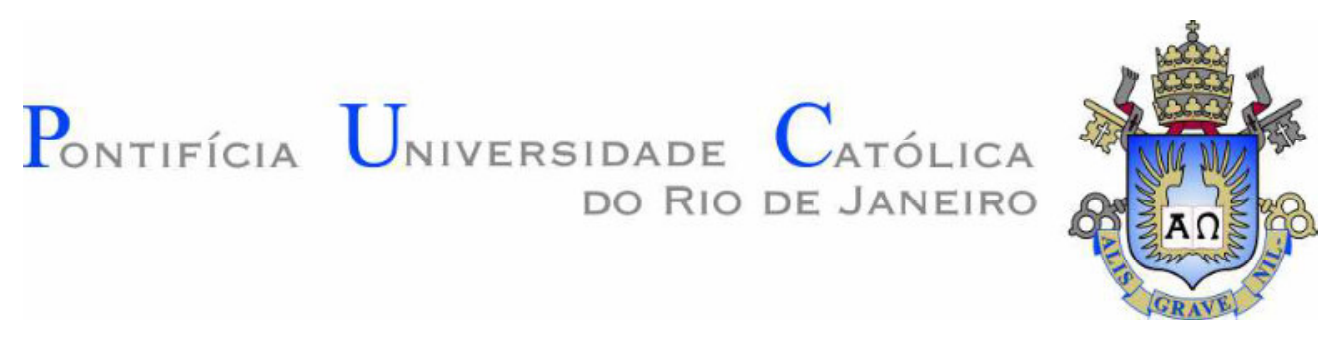

Clara Cyrino Lugão Silva

"De tudo se faz canção": Sobre as escolhas temáticas na música do Clube da Esquina

Orientador: Prof. Valter Sinder

Dissertação apresentada como requisito parcial para obtenção do grau de Mestre pelo Programa de Pósgraduação em Ciências Sociais da PUC-Rio.

Rio de Janeiro

Setembro de 2012 


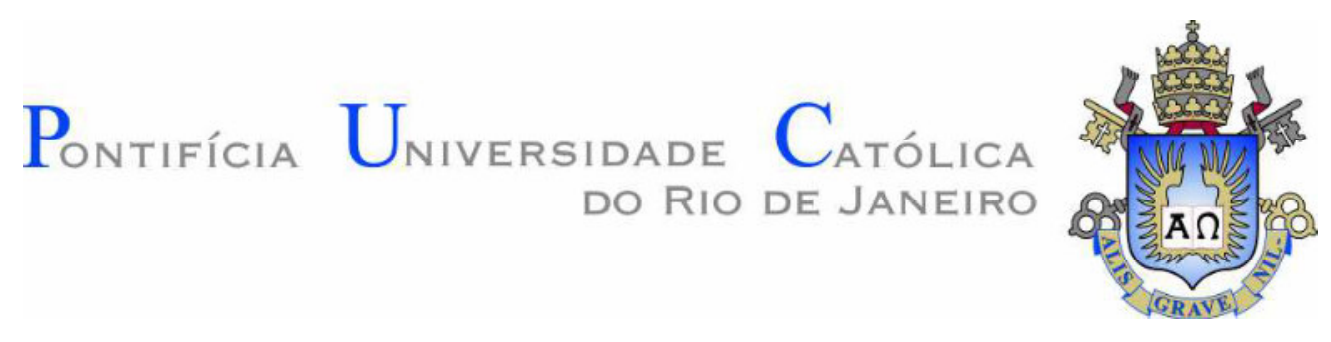

Clara Cyrino Lugão Silva

\title{
"De tudo se faz canção": Sobre as escolhas temáticas na música do Clube da Esquina
}

\begin{abstract}
Dissertação apresentada como requisito parcial para obtenção do título de Mestre pelo Programa de PósGraduação em Ciências Sociais da PUC-Rio. Aprovada pela Comissão Examinadora abaixo assinada.
\end{abstract}

Prof. Valter Sinder

Orientador

Departamento de Ciências Sociais - PUC-Rio

Prof. Nilton Silva dos Santos

UFF

Prof. Julio Cesar Valladão Diniz

Departamento de Letras - PUC-Rio

Profa. Mônica Herz

Coordenadora Setorial do Centro de Ciências Sociais - PUC-Rio

Rio de Janeiro, 21 de setembro de 2012 
Todos os direitos reservados. É proibida a reprodução total ou parcial do trabalho sem autorização da universidade, da autora e do orientador.

\section{Clara Cyrino Lugão Silva}

Graduou-se em Comunicação Social pela Pontifícia Universidade Católica do Rio de Janeiro (PUC-Rio) em 2008. Como pesquisadora, tem como interesse a Antropologia, com ênfase na Antropologia da Música.

Ficha Catalográfica

Silva, Clara Cyrino Lugão

De tudo se faz canção: sobre as escolhas temáticas na música do Clube da Esquina / Clara Cyrino Lugão Silva ; orientador: Valter Sinder. -2012.

115 f. : il. (color.) ; $30 \mathrm{~cm}$

Dissertação (mestrado)-Pontifícia Universidade Católica do Rio de Janeiro, Departamento de Sociologia e Política, 2012.

Inclui bibliografia 
Para Santuza Cambraia Naves, que ganhou minha admiração como orientadora, professora, autora e amiga, pessoa especial com quem tive a oportunidade de conviver e aprender tudo aquilo que quero fazer presente sempre, em cada trabalho. 


\section{Agradecimentos}

A Cesar e Odete Lugão, meus maiores amores, por terem feito canção de tantos momentos nossos.

A Rodrigo Silva, meu amor e melhor amigo, por dançar comigo no pó da estrada e por acreditar mais em mim do que eu mesma. Esse trabalho é seu também!

A Valter Sinder, pelas aulas inspiradoras que me transformaram enquanto pesquisadora e por ter me recebido tão generosa e atenciosamente como orientanda no momento em que mais precisei.

A Nilton Santos, pela leitura atenciosa, pelas sugestões fundamentais e pela confiança que demonstrou neste trabalho.

A Júlio Diniz, pela rica contribuição dada no exame de qualificação e pela participação nesse processo tão importante.

Tatiana Bacal é o maior presente que Santuza me deixou, amiga e grande exemplo de profissional. Nossas longas e deliciosas conversas e o convite para acompanhá-la em sala de aula marcarão para sempre minha formação.

À Sarah Silva Telles, por se mostrar sempre carinhosa e dedicada.

À Capes e à PUC-Rio, pela bolsa concedida.

A todos do Departamento de Ciências Sociais da PUC-Rio, minha "esquina". Em especial cito as queridas Ana Roxo e Mônica Gomes e os editores da Revista Desigualdade \& Diversidade.

Aos amigos da pós, meu “clube”. Em especial agradeço à Letícia Canegal, companhia perfeita para todo e qualquer momento; Victor Moretto, amigo sem igual, "irmão de orientação" e no amor à música; Janderson Bax, uma das pessoas mais incríveis que conheci na vida; Alberto Junqueira, pela leveza extraordinária e necessária que dá aos assuntos mais pesados; e aos queridos Renata Nabuco, Gustavo Guimarães, Jonas Lana e Guilherme Gonçalves pelas conversas e conselhos inspiradores. 
Agradeço todos os dias a alegria de ter por perto Érika Melek, Mariana Amorim e Yohana Mazza, para quem sempre posso "dizer com certeza outra vez a palavra amigo".

Ao casal Nathália e Gustavo Romanielo, que me proporcionaram grandes momentos de alegria e descontração durante esses anos de pesquisa.

A tantos outros bons amigos que me apoiam e alegram há muito tempo.

À minha família, pelos encontros sempre regidos pela música.

Aos meus sogros, Roberto Ricardo Theodoro e Maria das Graças Silva, pelo exemplo de carinho e respeito com que tratam tudo o que amam.

Agradeço muitíssimo aos músicos do Clube da Esquina, que junto com sua música se tornaram personagens principais deste trabalho, que foi para mim tão prazeroso. Em especial agradeço aos que me concederam entrevista e tornaram meus pensamentos sempre mais férteis.

Devo também um agradecimento às cidades, como Belo Horizonte, berço do Clube da Esquina, e aos mineiros que tão bem me receberam, em especial Claudia Brandão e Bruno Viveiros Martins. Ao Rio, minha casa, paisagem que escolhi para minha janela. À Volta Redonda, minha cidade, que traz o nome "e o coração na curva de um rio". 


\section{Resumo}

Silva, Clara Cyrino Lugão; Sinder, Valter (Orientador). "De tudo se faz canção": Sobre as escolhas temáticas na música do Clube da Esquina. Rio de Janeiro, 2012, 115p. Dissertação de Mestrado - Departamento de Ciências Sociais, Pontifícia Universidade Católica do Rio de Janeiro.

O presente trabalho tem como objeto as escolhas temáticas na música do Clube da Esquina, grupo de amigos cujo auge da produção musical se deu nos anos 1970, tendo como lugar de encontro a cidade de Belo Horizonte, em Minas Gerais. A questão central que vai guiar a análise das canções é como se dá a transformação das ideias, discussões e pensamentos dos envolvidos no grupo em música. O objetivo é entender aquilo que escolhem como tema e é objeto de uma fruição conjunta. Como "tema”, é importante pensar não apenas nos "assuntos", no que está nas letras das canções, mas também nas escolhas sonoras feitas na criação dessa produção musical. Dentre os principais temas analisados estão as influências culturais do Estado de Minas Gerais, a articulação destas com referências globais, os contextos social, político e cultural dos anos 1970 e grupos étnicos que têm em comum o fato de terem sido dominados em algum momento histórico. Bastante diversos e, em alguns casos, aparentemente opostos, esses temas estão presentes de forma harmônica na música do Clube da Esquina, o que mostra uma convivência entre a diversidade de referências dos vários integrantes, que se torna possível pela via da amizade.

\section{Palavras-Chave}

Clube da Esquina; escolhas temáticas; Música Popular Brasileira. 


\section{Abstract}

Silva, Clara Cyrino Lugão; Sinder, Valter (Advisor). "Anything becomes a song/ De tudo se faz canção": On the chosen themes in Clube da Esquina's music. Rio de Janeiro, 2012, 115p. MSc Dissertation - Departamento de Ciências Sociais, Pontifícia Universidade Católica do Rio de Janeiro.

This thesis is a study of the thematic choices made by the members of Clube da Esquina, a group of musical friends in Belo Horizonte, Minas Gerais, who were in their heyday in the 1970s. The central question that will guide the analysis of the songs is how ideas, thoughts and discussions of group members were transformed into music. The goal is to understand their choices of themes as objects of collective enjoyment. "Theme" here is taken to mean not only the subjects of song lyrics but also the musical choices made. Among the key themes analyzed are the cultural influences of Minas Gerais State, their relation with global references, the social, political and cultural context of the 1970s, and ethnic groups having as a common characteristic the fact that all were subjugated at some moment in history. Quite diversified and at times seemingly opposed to one another, these themes are harmoniously present in the music of Clube da Esquina, highlighting the coexistence of the different backgrounds of the various members, made possible by the ties of friendship.

\section{Keywords}

Clube da Esquina; chosen themes; Brazilian Popular Music. 


\section{Sumário}

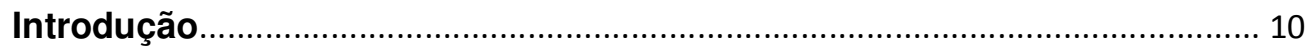

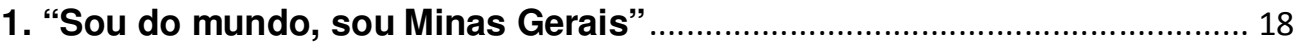

1.1. O Clube da Esquina e a mineiridade como repertório...................... 18

1.2. O Clube da Esquina e a articulação entre o local e o global ........... 37

2. "O que vocês fariam pra sair dessa maré?": O Clube da Esquina e seu tempo

3. "Tenho séculos de espera nas contas da minha costela". O Clube da Esquina e os grupos étnicos.

4. "E o que foi feito é preciso conhecer para melhor prosseguir": Uma produção musical pela via da amizade.

5. Posfácio: Embaralhando/ Desconstruindo Classificações 109

Referências Bibliográficas

Anexos 


\section{Introdução}

Quando um grupo de músicos se reúne para realizar um projeto musical, as possibilidades de temas a serem incorporados por eles são muitas. Por isso, ele tem que fazer escolhas. Tomando como objeto o Clube da Esquina, grupo de amigos e criadores de música cujo auge da produção se deu nos anos 1970, tendo como lugar de encontro a cidade de Belo Horizonte, em Minas Gerais, são essas escolhas que tento entender neste trabalho. A questão central que vai guiar a análise das canções é como se dá a transformação das ideias, discussões e pensamentos dos envolvidos no grupo em música. Quais são as tradições a que o grupo recorre para criar sua obra musical? O que eles levam para a canção daquilo que estão pensando juntos, de seu horizonte? De que forma falam desses temas?

É importante mencionar que não estou tratando da realidade explícita vivida por eles, mas daquilo que discutem enquanto grupo, do que escolhem como tema e é objeto de uma fruição conjunta. Quando digo "tema", não estou falando simplesmente dos "assuntos", daquilo que está nas letras das canções, mas também das escolhas sonoras, de melodia e ritmo. Entendo como tema nesta pesquisa as informações estéticas que estão se transformando em canção. Por isso o nome do trabalho é "De tudo se faz canção". Além de ser trecho de uma das canções analisadas, Clube da Esquina $n^{o} 2$ (álbum Clube da Esquina, 1972), funciona como provocação, pois parto da ideia de que não é realmente de tudo que a canção do Clube da Esquina é feita, mas de temas escolhidos dentro de um universo de possibilidades.

Trabalho o tema proposto através da análise da bibliografia pesquisada sobre o assunto, composta principalmente de livros de memórias sobre o grupo e das canções dos álbuns Clube da Esquina e Clube da Esquina 2. Tomo os ensaios, entrevistas e outros documentos produzidos pelos artistas e intelectuais que participam da vida cultural dos dois momentos citados como discursos nativos ${ }^{1}$,

\footnotetext{
${ }^{1}$ Para Eduardo Viveiros de Castro, "os discursos, o do antropólogo e sobretudo o do nativo, não são forçosamente textos: são quaisquer práticas de sentido. O essencial é que o discurso do antropólogo (o 'observador') estabeleça uma certa relação com o discurso do nativo (o 'observado')". VIVEIROS DE CASTRO, Eduardo. O Nativo Relativo. Mana, vol.8, n 1. Rio de Janeiro: Abril de 2002
} 
ou seja, como versões desses agentes sobre a sua atuação no cenário cultural do início dos anos 70, já que me pareceu fundamental pensar nas categorias expostas nos discursos dos próprios agentes culturais (músicos, artistas de diversas áreas e intelectuais em geral). O site oficial do Museu do Clube da Esquina ${ }^{2}$ também aparece como fonte de pesquisa importante, por oferecer informações, entrevistas e textos de apresentação.

O interesse pelo objeto surgiu da ligação pessoal com essa produção musical, que ouço desde a infância por influência familiar, e por acreditar que nela há questões que podem contribuir para o campo da antropologia da música ${ }^{3}$. Para isso, tento me deter à análise dos dois discos cuja realização contou com a participação de todos aqueles considerados integrantes do Clube da Esquina, ou seja, Clube da Esquina e Clube da Esquina 2. Os discos solo dos participantes, mesmo podendo ser considerados parte do "movimento", não serão contemplados nessa dissertação, embora algumas canções destes possam ser incluídas caso seja necessário.

Outro fator essencial na minha escolha do tema foi o meu interesse por manifestações artísticas em geral, em especial pela música, e ainda mais especificamente pela música brasileira. No meu trabalho de conclusão de curso na Graduação em Jornalismo, pesquisei os discursos sobre a cultura brasileira presentes nas canções do álbum Tropicália ou Panis et Circensis, de 1968, e desde então, procurei olhar para os objetos com os quais trabalho nesse campo através das ciências sociais, principalmente pela lente da antropologia. Pouco depois, uma matéria do jornal O Globo ${ }^{4}$ sobre os 35 anos do Clube da Esquina, em 2007, me chamou a atenção, porque tratava o grupo como "movimento", comparando-o com a bossa nova e a tropicália. Cogitei naquele momento que

\footnotetext{
${ }^{2}$ http://www.museuclubedaesquina.org.br/.

${ }^{3}$ Entendo o campo de antropologia da música como descrito por Tiago de Oliveira Pinto, que afirma: "Falando-se de antropologia do som, ou sonora, dois elementos surgem à primeira vista: o som enquanto fenômeno físico e, simultaneamente, inserido em concepções culturais, e, do outro lado, a música propriamente dita, isto é, o som "culturalmente organizado" pelo homem" (grifo meu). PINTO, Tiago de Oliveira. Som e música. Questões de uma Antropologia Sonora. Revista de Antropologia, vol.44, n.1. São Paulo: 2001.
}

${ }^{4}$ A matéria pode ser lida em http://oglobo.globo.com/cultura/mat/2007/12/15/327621578.asp 
talvez o assunto merecesse ser objeto de estudo a partir das ciências sociais. O fato de ser uma produção de um grupo de artistas bastante numeroso também se mostrou como ponto de grande interesse, por ser um fator que, pelo menos em tese, torna mais complexas as escolhas musicais.

Desde o início da pesquisa utilizo as entrevistas dos músicos mencionados disponíveis no Museu do Clube da Esquina (museu virtual criado por Márcio Borges) como fonte. Notei desde o princípio que o grupo tem uma forte reflexão sobre sua própria obra e sobre o papel do artista na sociedade, o que é estimulante não apenas por trazer novas questões, mas também como método para chegar às conclusões em relação às perguntas que eu estou me fazendo e ver as tensões entre as diferentes falas. Além das entrevistas já disponíveis em diversos meios, mostrou-se fundamental no decorrer da pesquisa que eu conversasse pessoalmente com alguns músicos do grupo, para que pudesse trazer para o trabalho as classificações nativas ${ }^{5}$.

O grupo de jovens compositores denominado Clube da Esquina surgiu entre os anos 1960 e 1970 em Belo Horizonte. Reunidos em torno de Milton Nascimento, vários músicos, principalmente mineiros, compunham o grupo, como Lô Borges, que assina junto com Milton os dois discos do grupo, Márcio Borges, Fernando Brant, Ronaldo Bastos, Wagner Tiso, Tavinho Moura, Beto Guedes, Robertinho Silva, Toninho Horta, Tavito, Luiz Alves, Nelson Angelo, Flávio Venturini, Murilo Antunes, Joyce e Novelli, entre outros. Digo ter sido em torno de Milton porque há concordância entre os integrantes do grupo sobre ser ele o principal agente aglutinador de todos os outros, como veremos mais detalhadamente ao longo do trabalho.

Os dois discos analisados foram lançados respectivamente em 1972 e 1978. A década de 1970 no Brasil foi, segundo José Miguel Wisnik, uma época "sem movimentos culturais típicos, sem grandes bandeiras" ${ }^{6}$. Para Santuza Cambraia Naves, “a geração 70 dá continuidade à maneira tropicalista de desconstruir a

\footnotetext{
${ }^{5}$ Para o desenvolvimento deste trabalho, entrevistei: Lô Borges, Fernando Brant, Márcio Borges, Ronaldo Bastos, Robertinho Silva, Tavinho Moura, Flávio Venturini, Nelson Angelo, Joyce e Danilo Caymmi.

${ }^{6}$ José Miguel Wisnik na apresentação do livro: BAHIANA, Ana Maria. Nada será como antes MPB nos anos 70. Rio de Janeiro: Civilização Brasileira, 1980.
} 
canção" e o "Clube da Esquina foi uma tendência da música popular brasileira com características próprias", com "melodias ricas e arranjos requintados, ritmos variados e letras que celebravam os recantos de Minas Gerais evocando um certo clima contracultural e ao mesmo tempo protestavam contra o momento político opressor que o país atravessava ${ }^{8}$ ". Segundo Marcelo Ridenti ${ }^{9}$, foi uma turma que se destacou tanto estética quanto politicamente depois do tropicalismo. Ele afirma que as arbitrariedades da censura e da repressão nos anos mais ferozes da ditadura fizeram com que Milton Nascimento vivesse mais intensamente do que nunca, como também conta Márcio Borges, os aspectos políticos, estéticos e filosóficos da vida. Ridenti cita também a ligação de Ronaldo Bastos com o Movimento Revolucionário 8 de outubro (MR-8) e suas letras que chamam para a luta guerrilheira como aspectos desse destaque estético e político que o Clube da Esquina significou para a música brasileira.

Nos anos 60, o conceito de MPB (Música Popular Brasileira) surgiu e passou a identificar as canções comerciais valorizadas culturalmente por certas camadas da sociedade. Segundo Marcos Napolitano, "adquirindo legitimidade perante a hierarquia cultural vigente, a MPB foi incorporada como signo de 'alta' cultura por uma parte substancial da elite cultural, política e econômica do Brasil ${ }^{10,}$, valor que continua vigorando na década seguinte e coloca a música do Clube da Esquina sob o mesmo conceito.

Para Liv Sovik, o livro O Balanço da Bossa, de Augusto de Campos, ao consagrar a bossa nova valorizando a ruptura e o avanço formais, emprestou prestígio à música popular brasileira por um bom tempo. A autora afirma ainda que a música

\footnotetext{
${ }^{7}$ A desconstrução da canção, segundo Naves, seria o fim do privilégio da correspondência entre música e letra no processo de composição, a impossibilidade, que surge a partir do Tropicalismo, de entender certos fenômenos musicais apenas por seus elementos poético-musicais. $\mathrm{O}$ assunto será abordado com maior profundidade no segundo capítulo.

${ }^{8}$ NAVES, Santuza Cambraia. Canção popular no Brasil: a canção crítica. Rio de Janeiro: Civilização Brasileira, 2010, p. 120.

${ }^{9}$ RIDENTI, Marcelo. Revolução Brasileira na Canção Popular. In: DUARTE, Paulo Sérgio e NAVES, Santuza Cambraia (orgs.). Do Samba-Canção à Tropicália. Rio de Janeiro: Relume Dumará: FAPERJ, 2003, p. 121.

${ }^{10}$ NAPOLITANO, Marcos. O conceito de "MPB" nos anos 60. In: História: Questões e Debates. Curitiba: Editora da UFPR, n. 31, p 11-30, 1999, p. 13.
} 
popular se estabeleceu, nos anos 1960, como terreno discursivo em que artistas teciam comentários sobre o estado das coisas no Brasil ${ }^{11}$.

Já Idelber Avelar ${ }^{12}$ entende que a MPB se consolidou nos anos 70 não só pela sofisticação que apresentava e pelas condições de censura, mas também por expressar uma relação com o nacional já purgada do sectarismo exclusivista que foi parte da sigla em seu período de emergência, nos festivais dos anos 60 . O autor concorda com o caráter de excepcionalidade e distinção de uma classe social projetado nesse produto cultural.

Entrevistado por Ana Maria Bahiana, Gonzaguinha traz um discurso interessante sobre essa valorização e sobre a expectativa do público em relação aos artistas e suas obras. Ele diz que "este país só vive tendo um ídolo, um padrão, um modelo. E estão querendo pôr o Milton [Nascimento] lá. O trono está prontinho pra ele sentar ${ }^{13}$ ". Sobre o assunto, Miguel Jost Ramos afirma que esse trono não era do mesmo tipo daquele em que Pelé e Roberto Carlos se sentaram, mas "era na verdade um trono destinado ao consumo intelectual e político de uma parcela da sociedade brasileira que tinha formado seus critérios estéticos a partir das rupturas propostas pela bossa nova e pelo tropicalismo ${ }^{14,}$.

De acordo com Ramos,

O incômodo que gerava esse novo lugar do artista/ ativista/ intelectual permaneceria como uma marca da década de 70 e até hoje se constitui numa característica cultural brasileira. Chico e Caetano foram os primeiros a enfrentar esta situação e experimentaram todo tipo de reação às expectativas criadas em cima deles. Passaram a década tentando reduzir estas

\footnotetext{
${ }^{11}$ SOVIK, Liv. Aqui ninguém é branco. Rio de Janeiro: Aeroplano, 2009, p. 92.

${ }^{12}$ AVELAR, Idelber. De Milton ao Metal: Política e Música em Minas. Disponível em: http://www.hist.puc.cl/iaspm/rio/Anais2004\%20\%28PDF\%29/IdelberAvelar.pdf.

${ }^{13}$ BAHIANA, Ana Maria. Nada será como antes - MPB nos anos 70. Rio de Janeiro: Civilização Brasileira, 1980, p. 47.

${ }^{14}$ RAMOS, Miguel Jost. Chico e Caetano juntos e ao vivo na década de 70. In: GIUMBELLI, Emerson, DINIZ, Júlio Cesar Valladão e NAVES, Santuza Cambraia (orgs.). Leituras sobre música popular: reflexões sobre sonoridades e cultura. Rio de Janeiro: 7Letras, 2008, p.284.
} 
expectativas e fugindo da função de voz de uma geração ou de porta-bandeira das causas nacionais ${ }^{15}$.

Embora não seja possível afirmar se foi por timidez, falta de vontade ou de vocação, acredito que seja possível sugerir que Milton nunca tenha sentado nesse trono, se colocado nessa posição de porta voz, assim como os outros integrantes do Clube, que não são frequentemente chamados a opinar em diversos meios sobre questões de debate nacional e até internacional, como acontece com os citados Caetano Veloso e Gilberto Gil, entre outros. A maneira recorrente de expressão dos artistas do Clube da Esquina tem sido a música. Na entrevista mencionada, Milton declarou: "Eu tenho a minha música. E é só, é só a minha música. As coisas que eu faço são só isso, um momento meu posto em música ${ }^{16 "}$.

Essa fala demonstra uma postura que não é comum a todos os integrantes do Clube da Esquina, o que aparece como uma questão importante a ser discutida aqui, quando trato do cenário político e cultural dos anos 1970. Alguns trazem um discurso de separação entre política e estética enquanto outros vêem a obra em questão como uma manifestação de ideais políticos através da arte. Essa diferença está relacionada à postura individual desses músicos, como pretendo discutir ao tratar dos temas políticos e sociais presentes na música do grupo, falando dessas individualidades ${ }^{17}$ e de como as referências de cada um aparecem na música, o que é perceptível não apenas no caso dessas questões sociais e políticas, mas para muitas outras que serão analisadas.

O Clube surge nesse momento pós-tropicália, numa década considerada por muitos autores como pobre e desorganizada culturalmente. Contrapondo-se a essa visão majoritária, Carlos Alberto Messeder Pereira ${ }^{18}$ analisa a poesia da época como exemplo da existência de um debate intelectual vigoroso. As grandes

\footnotetext{
${ }^{15}$ RAMOS, Miguel Jost. Chico e Caetano juntos e ao vivo na década de 70. In: GIUMBELLI, Emerson, DINIZ, Júlio Cesar Valladão e NAVES, Santuza Cambraia (orgs.). Leituras sobre música popular: reflexões sobre sonoridades e cultura. Rio de Janeiro: 7Letras, 2008, p. 288.

${ }^{16}$ Trecho de entrevista de Milton Nascimento em BAHIANA, Ana Maria. Nada será como antes MPB nos anos 70. Rio de Janeiro: Civilização Brasileira, 1980, p. 48.

${ }^{17}$ A questão citada é explorada no capítulo de conclusão, em que procuro relacionar as várias referências citadas ao longo do trabalho com a história de alguns integrantes.

${ }^{18}$ PEREIRA, Carlos Alberto Messeder. Retrato de época: poesia marginal anos 70 . Rio de Janeiro, FUNARTE, 1981, p. 32.
} 
questões da década de 60 e a imensa movimentação que exigiam foram substituídas nos anos 70 pelo que ele define como "politização do cotidiano", em que elas são trabalhadas como interferências no cotidiano das pessoas. Para o autor,

Numa época marcada pela vivência muito direta de profundas contradições, não faltaram violentas 'cobranças de posição' que, por mais que tentassem tornar coerente um processo que não aparecia como tal aos olhos dos que o estavam vivendo, só faziam aumentar o caráter dilacerador daquele momento; (...) Algumas 'certezas fundamentais' apoiadas no discurso crítico tradicional de esquerda cedem lugar à incerteza do 'desbunde'. Cada vez com mais vigor, a cena cultural é tomada pelas idéias da 'contracultura', rótulo com que se passa a designar de modo não muito apropriado os diversos movimentos de rebelião de setores significativos da juventude dos diversos países ocidentais ${ }^{19}$.

E essa cobrança de posição foi importante para o Cube da Esquina, que tomou a resistência e a crítica ao regime ditatorial que governava o Brasil como um de seus temas.

No primeiro capítulo, utilizo o depoimento dos músicos e estudiosos do Clube da Esquina para entender o que há nessas canções que é considerado próprio de uma "mineiridade". A partir dessas falas, o repertório explorado vai se centrar em pontos como a relação da produção com a história da cidade de Belo Horizonte e do Estado de Minas Gerais, suas tradições culturais e musicais; o modo como opera com referências antigas e modernas em um mesmo projeto; a música religiosa e sua dimensão coral; a relação com algumas ideias do conceito de Barroco com o qual trabalho; e o diálogo com a juventude mineira.

Passo desses temas regionais para a discussão sobre a articulação entre eles e referências universais, que parece amparar as realizações do Clube. Parto da ideia de que as canções do grupo tratam de elementos locais que se articulam com os globais. Assim, analiso as canções e os depoimentos dos músicos para buscar compreender o que os levou a tematizar poética e musicalmente o continente latino-americano e a cidade de Belo Horizonte como lugar em que se imagina o global, trazendo influências internacionais para essa produção.

\footnotetext{
${ }^{19}$ Idem, p. 32.
} 
No segundo capítulo, busco esmiuçar as ideias já trabalhadas nesta introdução sobre a relação do contexto dos anos 1970 com a música do Clube da Esquina, como os conceitos de "politização do cotidiano" e sensibilidade contracultural, para pensar o modo como o grupo articula arte e posicionamento político. Termino embarcando na discussão sobre o Clube ser ou não um movimento.

No terceiro capítulo, parto da análise de Paul Gilroy sobre a arte negra no Atlântico para pensar a forma como a música do Clube da Esquina tematiza três grupos étnicos: latinos, negros e índios.

No capítulo de conclusão, tento reunir as especificidades da música do Clube da Esquina apresentadas em todo o trabalho e situar essa produção em relação a outros grupos da música popular brasileira que foram objeto de estudo de diversos autores. Além disso, procuro nesse ponto entender o conceito de amizade e como esse tipo de relação, existente entre os músicos estudados, influenciam nessa produção musical. Assim busco analisar a existência dos temas citados de forma recorrente na música do Clube da Esquina.

Para Luiz Henrique Assis Garcia:

a escolha do repertório, das influências, dos estilos, tudo isso evidencia os posicionamentos do grupo em relação ao seu passado, seu presente e seu futuro. Esta posição aparece sintetizada numa frase de (Maria Céres) Castro que esperamos desdobrar: o Clube da Esquina busca "(...) integrar - de forma crítica e radical - os tempos passados nas incertezas do futuro ${ }^{20 "}$.

Neste trabalho, pretendo apontar algumas análises sobre essa escolha de repertório. Procuro partir daquilo que a músicas do grupo tematizam, tomando o discurso musical como ponto principal, para então pensar o que os músicos dizem sobre as canções, o que os estudiosos sobre o assunto apontam e até mesmo as opiniões dos ouvintes do Clube da Esquina para responder à pergunta que me fiz, sobre os temas presentes nessa produção musical.

\footnotetext{
${ }^{20}$ GARCIA, Luiz Henrique Assis. Coisas que ficaram muito tempo por dizer: O Clube da Esquina como formação cultural. Dissertação apresentada ao Curso de Mestrado do Programa de PósGraduação do Departamento de História da Faculdade Filosofia e Ciências Humanas da Universidade Federal de Minas Gerais, 2000, p. 10.
} 


\section{1. "Sou do mundo, sou Minas Gerais"}

\subsection{O Clube da Esquina e a mineiridade como repertório}

Uma das frases que mais ouvi de muitos interlocutores durante a pesquisa sobre o Clube da Esquina foi "Eles são tão mineiros". Achei válido então começar a discussão sobre os temas escolhidos para a música do grupo tratando dessa identidade mineira, que é mais perceptível na música analisada do que uma identidade nacional, brasileira ou de outras regiões específicas como o Rio de Janeiro, de onde também são muitos integrantes. Na audição das músicas procurei o que era mineiro ali e me surpreendi ao descobrir que talvez a mineiridade não fosse apenas um tema, mas um repertório de temas do Clube da Esquina.

Nessa abordagem, é importante diferenciar "mineiridade" de "mineirice", sendo o último um conceito ligado à esperteza escondida ou disfarçada em uma aparência de ingenuidade, atribuída aos mineiros, muitas vezes de forma pejorativa, como um estereótipo. Já o primeiro, que investigo aqui, está relacionado ao que é culturalmente comum entre eles, características, tradições e hábitos frequentemente encontrados nos habitantes de Minas Gerais, mas que não devem ser entendidas como regras absolutas.

Sugiro uma relativização de certos aspectos normalmente considerados como caracteristicamente mineiros na música do Clube da Esquina. Se em Paisagem da Janela $^{21}$, por exemplo, quando o sujeito lírico olha pela "janela lateral do quarto de dormir" e vê "uma igreja, um sinal de glória, um muro branco e um vôo pássaro", a paisagem parece muito mineira, nada impede que seja de outro lugar. É possível que um ouvinte de qualquer cidade ou país, por mais distante, reconheça sua paisagem nessas palavras.

Da mesma forma, o trem, meio de transporte tão presente no imaginário sobre Minas Gerais, aparece muitas vezes nas letras das canções, mas essa presença por si só não torna uma música mineira. É uma referência importante, mas não é, sozinha, reveladora de uma mineiridade. Da mesma forma, os ritmos e os arranjos

\footnotetext{
${ }^{21}$ Canção de Lô Borges e Fernando Brant (álbum Clube da Esquina, 1972).
} 
produzidos pelo grupo não são marcados, separadamente, como próprios de Minas Gerais, mas é possível encontrar referências à música das festas folclóricas e religiosas da região, como veremos.

O que aponto aqui é que nenhum desses elementos isoladamente marca a música do Clube da Esquina como uma música mineira, e sim a junção de todos eles, o fato de terem sido escolhidos como parte dessa produção musical. Vejamos alguns discursos de estudiosos sobre o assunto, como Rafael Senra Coelho e Bruno Viveiros Martins, e de alguns integrantes do grupo, como Milton Nascimento, Robertinho Silva, Tavinho Moura, Márcio Borges e Nivaldo Ornelas, sobre a mineiridade presente na música do Clube da Esquina.

A identidade mineira, como qualquer processo de formação de um povo, é marcada por equívocos, contradições, e também por fatos, relatos, e relembranças. Assim como fizeram os modernistas e memorialistas mineiros, como Carlos Drummond de Andrade ou Murilo Mendes, o ato da evocação da memória de Minas Gerais foi não só um recurso estético para o Clube da Esquina, mas também uma forma de protestar contra a ditadura militar, através da dimensão artística22.

Nova maneira de viver e experimentar a canção brasileira, o Clube da Esquina surpreendeu o país ao combinar, de maneira inovadora, o que havia de mais atual em circulação pelas capitais do mundo com os particularismos da base cultural mineira de fundo arcaico e provincial ${ }^{23}$.

Sempre digo que meus primeiros parceiros na música foram as montanhas de Minas. Fui criado o tempo todo em Minas. Como uma pessoa pode pensar que eu não sou mineiro ${ }^{24}$ ?

Então a música mineira foi uma música que me pegou de surpresa. Falei assim: "Caramba, que música diferente e bonita!" E eles me davam muita liberdade de criação. Ninguém impunha nada. "Você tem que tocar assim, tem que tocar assado." Eu falei: "Oba!" Era uma liberdade dessa. Então tudo que eu sabia de ritmo, eu empregava ali. Toda informação que estava embutida aqui, que estava enrustida, eu podia usar. Tinha liberdade de criação. Foi uma conquista assim. As pessoas dizem que eu sou um baterista diferente. Mas foi por causa dessa música que eu me tornei diferente. Adquiri até um estilo

\footnotetext{
${ }^{22}$ COELHO, Rafael Senra. Dois lados da mesma viagem: A Mineiridade e o Clube da Esquina. Dissertação de Mestrado. Promel - UFSJ: São João del-Rei, 2010, p. 103.

${ }^{23}$ MARTINS, Bruno Viveiros. Som Imaginário: a reinvenção das cidades nas canções do Clube da Esquina. Belo Horizonte: Editora UFMG, 2009, p.12.

${ }^{24}$ NASCIMENTO, Milton. Parceiro das Montanhas: Entrevista concedida ao jornal Estado de Minas/ Caderno Pensar. Sábado, 30 de maio de 2009.
} 
através da música mineira ${ }^{25}$. Sou carioca, mas já fui mineiro eu $\operatorname{sei}^{26}$.

Todos nós crescemos ouvindo a música das festas de rua de Minas, das folias de reis. O Beto Guedes ouvia Beatles, mas é de Montes Claros, também ouvia o pai dele muitas coisas regionais que estão na música dele. (...) Acho que a mineiridade na nossa música está na introspecção, no pensar bastante antes de fazer, com tranquilidade, essas coisas bem mineiras ${ }^{27}$.

Eu vejo Minas na música do Milton principalmente naquela coisa do interior, de Três Pontas, no gosto característico do pessoal lá, a coisa da vida do interior mesmo, um outro ritmo, a estética religiosa, as procissões, as ruas coloridas, com flores. Santa Tereza tinha a mesma coisa, porque era quase uma cidade do interior. Mas eu era mais urbano, acelerado. Não tinha nada em Três Pontas e esse "não acontecer nada" marcou o ritmo da música do Bituca [Milton Nascimento], a cadência. O pessoal que veio do interior trouxe essa lentidão, fazer a digestão calmamente e depois dizer se gostou. Mas o Clube misturou demais as duas coisas. Eu brinco que botei um foguete de cada lado no Bituca, acelerei um pouco o processo ${ }^{28}$.

No meu caso próprio, meu e dos outros, a gente tinha uma cultura forte de evidenciar as folias de reis, o congado, música religiosa. Você sabe que Minas Gerais, Belo Horizonte, tinha várias missões religiosas que vieram da Europa? Tinha missão holandesa... Tinha o colégio Santo Agostinho, ali era uma missão espanhola. (...) Isso era muito forte, a música religiosa mineira influenciou profundamente a música do Tavinho Moura, do Milton, a minha. Então, a identidade mineira, da música popular, começou a formar a partir daí, eu acho. Porque até então era música folclórica, estas manifestações são músicas folclóricas. Música popular mesmo, começou a formar a partir daí. E a do Milton como o seu principal articulador ${ }^{29}$.

Embora exista dentro do Clube da Esquina o que é chamado de "grupo dos mineiros", formado principalmente por Milton Nascimento, Lô Borges, Márcio Borges, Fernando Brant, Tavinho Moura, Wagner Tiso, Beto Guedes, Flávio Venturini e Toninho Horta, e o "grupo do Rio", que tem entre seus nomes os de Ronaldo Bastos, Robertinho Silva, Luiz Alves, Joyce, Danilo Caymmi e Paulo Jobim, de acordo com os depoimentos dos integrantes, há um consenso sobre a

\footnotetext{
${ }^{25}$ Robertinho Silva em depoimento ao Museu do Clube da Esquina.

${ }^{26}$ Robertinho Silva em depoimento concedido para esta pesquisa.

27 Tavinho Moura em concedido para esta pesquisa.

${ }^{28}$ Márcio Borges em depoimento concedido para esta pesquisa.

${ }^{29}$ ORNELAS, Nivaldo. Entrevista feita por Rafael Senra com o músico Nivaldo Ornelas no festival Conexão Vivo. Gravada em 15 de março de 2009.
} 
existência de uma mineiridade na produção aqui estudada. Mas o mesmo não acontece em relação a quais são essas características mineiras, o que gera dúvidas sobre a origem da relação da música analisada com a identidade mineira e estimula a investigação sobre a forma como esta é tematizada.

Sobre a existência desses dois grupos principais, de mineiros e cariocas, em nenhum momento ela apareceu como disputa. É fator de concordância entre eles que há influências de muitas outras regiões, mas que o centro criativo dessa produção estava no grupo mineiro, principalmente pelo fato de que todos veem Milton Nascimento como núcleo que reúne esses músicos em torno de si. É interessante nesse ponto inclusive a diferenciação feita entre os compositores criados na capital e os do interior do estado, como Milton e Wagner Tiso, de Três Pontas, aos quais é creditada a introspecção e um tempo maior de "digestão" no fazer musical.

Nos depoimentos citados, a mineiridade da música do Clube da Esquina é relacionada com a evocação de memória da região, com a convivência de temas contraditórios e do moderno com o tradicional, com liberdade de criação, com a paisagem local, as festas de ruas, a religião, e com termos como "tranquilidade", "introspecção" e "lentidão". Se essas questões emprestam ao objeto deste trabalho uma identidade mineira, a música do grupo também fortalece essas características como próprias de Minas Gerais, ou seja, o Clube da Esquina acaba mantendo e até mesmo criando o que é caracteristicamente mineiro. 40 anos depois do lançamento do primeiro disco do grupo, as características da música do Clube da Esquina acabaram se tornando também características mineiras. Várias propagandas turísticas ou do governo, matérias jornalísticas, novelas e programas de TV sobre a região frequentemente têm como trilha sonora alguma música do grupo $^{30}$. Para falar de Minas, pelo menos culturalmente, tornou-se necessário considerar o Clube da Esquina.

A eleição de um poema de Carlos Drummond de Andrade (Canção Amiga), um dos mais famosos filhos de Minas Gerais, para ser musicado e fazer parte do

\footnotetext{
${ }^{30}$ Um exemplo possível de ser verificado é a trilha sonora da novela "Coração de Estudante", exibida pela Rede Globo em 2002, passada em uma cidade fictícia de Minas Gerais. Além do próprio nome da novela ter inspiração na música homônima de Milton Nascimento e Wagner Tiso, a trilha sonora tinha cinco canções de integrantes do Clube da Esquina.
} 
álbum Clube da Esquina 2 também é representativa dessas escolhas que marcam a identidade mineira na obra.

Eu preparo uma canção/ Em que minha mãe se reconheça/ Todas as mães se reconheçam/ e que fale como dois olhos ${ }^{31}$

A capital mineira, Belo Horizonte, foi o local de encontro e construção do Clube, cuja "esquina" fica entre as ruas Divinópolis e Paraisópolis, no bairro de Santa Tereza. Um fato interessante que mostra a forte ligação dessa produção com a cidade é o Guia de Belo Horizonte: roteiro Clube da Esquina, lançado pelo Museu do Clube da Esquina, em que são apresentados 25 locais que fazem parte da história dos mineiros do grupo. Em todos eles, foram colocadas placas identificando essa relação. Na publicação, Belo Horizonte é apresentada como uma cidade múltipla, "ora metrópole efervescente, ora centro acolhedor de antigas tradições ${ }^{32}$, e também como cidade de música, de política e poesia. "Há um som que vem da história colonial de Minas, que se junta ao cântico das festas religiosas, que se une aos cantos de trabalho e aos ruídos do mundo ${ }^{33, "}$

Tive a oportunidade de visitar alguns lugares que receberam as placas e pude perceber como elas dão à cidade uma ideia de institucionalização do Clube da Esquina e da sua "mineiridade", o que, como veremos, não é visto com bons olhos por todos os integrantes.

\footnotetext{
${ }^{31}$ Trecho da canção Canção Amiga, de Milton Nascimento e Carlos Drummond de Andrade, álbum Clube da Esquina 2, 1978.

${ }^{32}$ MUSEU CLUBE DA ESQUINA. Guia turístico de Belo Horizonte: roteiro Clube da Esquina/ Museu Clube da Esquina - Belo Horizonte, 2011, p. 7.

${ }^{33}$ MUSEU CLUBE DA ESQUINA. Guia turístico de Belo Horizonte: roteiro Clube da Esquina/ Museu Clube da Esquina - Belo Horizonte, 2011, p. 14.
} 


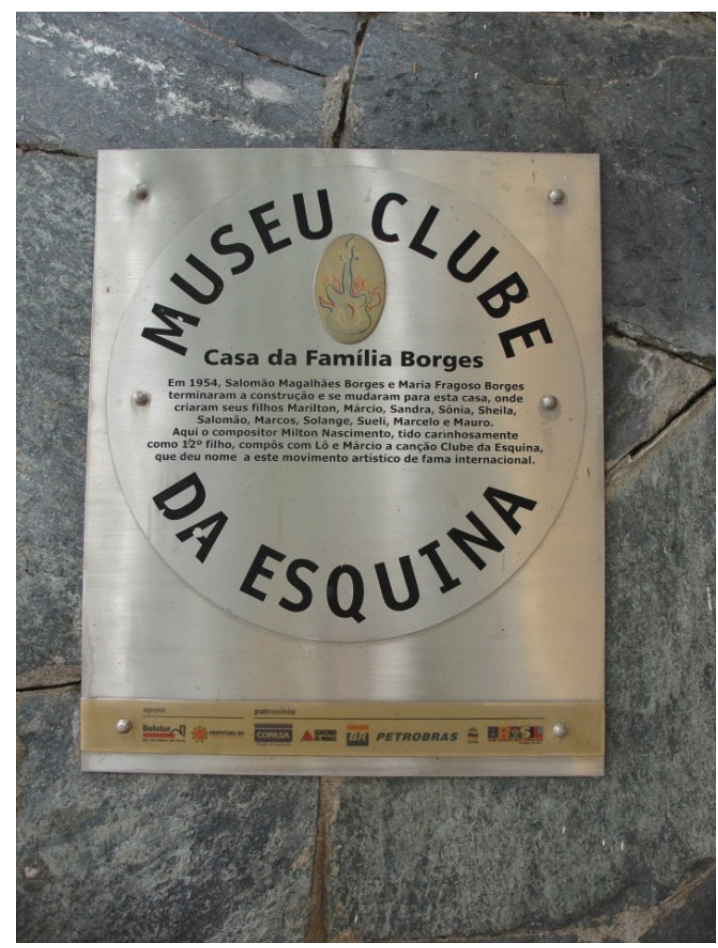

A placa da foto acima indica: "Casa da Família Borges: Em 1954, Salomão Magalhães Borges e Maria Fragoso Borges terminaram a construção e se mudaram para esta casa, onde criaram seus filhos Marilton, Márcio, Sandra, Sônia, Sheila, Salomão, Marcos, Solange, Sueli, Marcelo e Mauro. Aqui o compositor Milton Nascimento, tido carinhosamente como $12^{\circ}$ filho, compôs com Lô e Márcio a canção Clube da Esquina, que deu nome a esse movimento artístico de fama internacional".

A ligação de Belo Horizonte com o Clube da Esquina é tão forte que até hoje as novidades na cena musical belo-horizontina são comparadas com o grupo, mostradas como continuidades ou rupturas em relação à música feita por eles. Um exemplo disso é a reportagem publicada em 31 de maio de 2011 pelo jornal O Globo sobre novas bandas da cidade, chamada "Novas Esquinas", em que a "herança mineira" do Clube da Esquina é citada várias vezes. É reveladora a fala de um dos novos artistas entrevistados, Pedro Morais, que reconhece essa herança, mas faz questão de afirmar que "não estamos sob a sombra dessa influência. Essa é uma geração que não depende do aval de Milton Nascimento, que amo, com

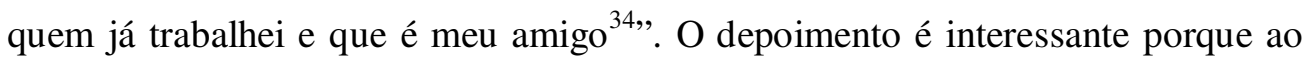
mesmo tempo em que tenta desvincular a produção atual da música do Clube da

\footnotetext{
${ }^{34}$ A reportagem pode ser encontrada em http://oglobo.globo.com/cultura/mat/2011/05/30/a-cenamusical-contemporanea-de-minas-chama-atencao-pelo-talento-pela-forma-como-se-estrutura924565011.asp.
} 
Esquina, mostra Milton como uma referência importante e revela a existência de uma relação de respeito para com o grupo dos anos 70 .

Sobre a posição da cidade em relação a Minas e ao Brasil, o arquiteto e urbanista Roberto Luís M. Monte-Mór ${ }^{35}$ esclarece alguns pontos. Para ele, o modelo urbanístico foi usado, em Belo Horizonte, para criar uma cidade que respondesse aos anseios de modernidade dos mineiros, sobretudo dos agricultores e pecuaristas.

Belo Horizonte nasceu assim com pretensões progressistas e modernistas, simulacro oligárquico do espaço de poder de uma burguesia republicana existente, espaço positivista e barroco, uma contradição em termos. De fato, o urbanismo burguês de inspiração barroca foi também uma tentativa conservadora de impedir que o industrial dela se apossasse, livrando-a da feiúra de máquinas fumacentas $(. . .)^{36}$.

É muito elucidativa sobre a identidade da capital mineira e sobre o Clube da Esquina a contradição sobre a qual o autor fala. Ela se relaciona tanto com a reunião feita entre o moderno e o tradicional quanto com a valorização da vida rural na produção musical analisada.

Sair dessa cidade ter a vida onde ela é/ Subir novas montanhas, diamantes procurar/ no fim da estrada e da poeira/ um rio com seus frutos me alimentar ${ }^{37}$

Um pé na soleira e um pé na calçada, um pião/ Um passo na estrada e um pulo no mato/ Um pedaço de pau/ Um pé de sapato e um pé de moleque ${ }^{38}$

Nas melodias, a mistura entre antigo e moderno tem música de igreja, Beatles, jazz, bossa-nova, guitarras, percussão, violas, muito coro, violinos, charango, zampona $^{39}$, bombo legüero ${ }^{40}$ e muitas outras influências. Nas letras, temas indígenas, folclóricos, católicos, políticos e amorosos, entre outros.

\footnotetext{
${ }^{35}$ MONTE-MÓR, Roberto Luís M., Belo Horizonte, Capital de Minas, século XXI. In: Varia História. Belo Horizonte, n.18, novembro de 1997, p. 477.

${ }^{36}$ Idem.

${ }^{37}$ Trecho da canção Saídas e Bandeiras $\mathbf{N}^{\mathbf{0}} \mathbf{1}$, de Milton Nascimento e Fernando Brant, álbum Clube da Esquina, 1972.

${ }^{38}$ Trecho da canção Léo, de Milton Nascimento e Chico Buarque de Hollanda, álbum Clube da Esquina 2, 1978.

${ }^{39}$ Charango e zampona são instrumentos tipicamente andinos.
} 
Uma dessas influências cuja análise se mostra importante é o coro. Segundo Flora Süssekind ${ }^{41}$, que trata do coro não apenas na área musical, a dimensão coral é característica da produção cultural brasileira do fim dos anos 60. Ela é utilizada inicialmente para apresentar uma homogeneidade coral, um possível paralelismo na ação coletiva, uma confluência de interesses ou pensamento, como no exemplo da canção Pra não dizer que não falei de flores, defendida por Geraldo Vandré no Festival da Canção de 1968, em que "as 20 mil pessoas que estavam no Maracanãzinho transformaram-se em coral $^{42}$ ". A autora afirma que essa função muda, é substituída por outras até mesmo contrárias, como no caso da tropicália, em que o coro é utilizado para expor as cisões do público.

Acredito que nos dois discos analisados, em que das 44 músicas, 19 têm coro, seja justamente a vontade de induzir a uma sensação de unidade o motivo da utilização do coral. Nessa escolha, fica clara a influência da música religiosa no Clube da Esquina, o que pode ser relacionado com a força da Igreja Católica na região. Os coros dão uma ideia de grupo unido, forte, que tem um sentimento em comum. A maioria deles é composta pelos próprios compositores e por vários amigos que eram convidados para participar das gravações, mas há também a participação dos Canarinhos de Petrópolis, um dos corais mais conhecidos do país.

Para Rafael Senra Coelho ${ }^{43}$, a inclusão de elementos religiosos é um aspecto muito presente ao longo da carreira de Milton, seja nas letras, melodias, escolha de instrumentos, capa dos discos ou até em sua interpretação vocal. O autor afirma que esse caráter religioso começa circunscrito ao catolicismo, mas depois agrega elementos de religiões africanas e indígenas, construindo um "panorama religioso mais amplo ${ }^{44,}$. Esse panorama já aparece nas duas obras aqui analisadas,

\footnotetext{
${ }^{40}$ Bombo legüero é um instrumento comumente usado na música folclórica argentina.

${ }^{41}$ SÜSSEKIND, Flora. Coro, contrário, massa: a experiência tropicalista e o Brasil de fins dos anos 60. In: BASUALDO, Carlos (org.). Tropicália - Uma revolução na cultura brasileira. São Paulo: Cosac Naify, 2007, p. 47.

${ }^{42}$ Idem.

${ }^{43}$ COELHO, Rafael Senra. Dois lados da mesma viagem: A Mineiridade e o Clube da Esquina. Dissertação de Mestrado. Promel - UFSJ: São João del-Rei, 2010, p.63.

${ }^{44}$ Idem.
} 
em que não apenas influências da música da igreja e das festas católicas estão presentes, mas também da música de rituais indígenas.

Em San Vicente ${ }^{45}$, a partir da metade da música entra o toque de um sino que se destaca porque começa no mesmo ritmo dos instrumentos, mas logo se descola dele e fica em primeiro plano até ser o único som ao final da música, lembrando claramente o chamado para uma missa. Um trecho da mesma música é retomado no início de $\mathrm{Credo}^{46}$, primeira canção do Clube da Esquina 2, remetendo ao disco feito seis anos antes, só que desta vez cantada em coro, sem instrumentos, como em uma grande procissão.

Em Paixão e $\mathrm{Fe}^{47}$, uma das músicas em que há a participação dos Canarinhos de Petrópolis, a temática religiosa é bastante clara. A melodia foi composta por Tavinho Moura a partir das fotografias de uma procissão em Diamantina feitas por Zé Luiz Pederneiras, do Grupo Corpo $^{48}$.

Já bate o sino, bate na catedral/ E o som penetra todos os portais/ A igreja está chamando os seus fiéis/ Para rezar por seu senhor/ Para cantar a ressurreição ${ }^{49}$

Já em Canoa, Canoa ${ }^{50}$, o coral formado por integrantes do grupo remete a alguns cantos indígenas. A música começa com o toque de um bambu e pios imitando pássaros, além da flauta, que levam o ouvinte para o meio dos Avacanoê, etnia indígena citada na letra. $\mathrm{O}$ coro responde à voz de Milton, como num ritual.

Avacanoeiro prefere as águas/ Avacanoeiro prefere os rios/ Avacanoeiro prefere os peixes/ Avacanoeiro prefere remar ${ }^{51}$

As canções Reis e Rainhas do Maracatu e A Sede do Peixe também citam, em suas letras, temas religiosos.

\footnotetext{
${ }^{45}$ San Vicente, canção de Milton Nascimento e Fernando Brant, álbum Clube da Esquina, 1972.

${ }^{46}$ Credo, canção de Milton Nascimento e Fernando Brant, álbum Clube da Esquina 2, 1978.

${ }^{47}$ Paixão e Fé, canção de Tavinho Moura e Fernando Brant, álbum Clube da Esquina 2, 1978.

${ }^{48}$ O Grupo Corpo é uma companhia de dança fundada em 1975, em Belo Horizonte.

49 Trecho da canção Paixão e Fé, de Tavinho Moura e Fernando Brant, álbum Clube da Esquina 2, 1978.

${ }^{50}$ Canoa, canoa, canção de Nelson Angelo e Fernando Brant, álbum Clube da Esquina 2, 1978.

${ }^{51}$ Trecho da canção Canoa, canoa, de Nelson Angelo e Fernando Brant, álbum Clube da Esquina 2, 1978 .
} 
A nação maracatu, nosso tema geral/ Vem do negro esta festa de reis ${ }^{52}$

Para o que não tem solução/ A sede do peixe ensinou/ Não me vale a água do mar/ Nem vinho, nem glória, navio ${ }^{53}$

Sobre a religiosidade, Coelho diz que Milton Nascimento afirma não ser "místico", mas usar tais elementos mais "no sentido político do que no religioso 54 ". Essa afirmação manifesta como uma influência pode ser transformada pelos agentes, afastando-se do seu significado original, construindo uma relação muito diferente daquele em que foi ouvida primeiramente, ou seja, a música produzida para louvar às divindades e valorizar os temas religiosos é ressignificada, transformada numa crítica à própria religião.

Esses elementos (...) têm um cunho mais político que religioso nas minhas músicas, uma coisa de briga com a opressão, principalmente contra o que a Igreja botou em cima da gente, né? O que a Igreja e os padres fizeram e fazem, com a gente principalmente, é uma loucura ${ }^{55}$.

Vejamos a afirmação de Idelber Avelar sobre o valor dos temas religiosos na música de Milton:

(...) nos anos 70 a música de Milton - com a rica textura de suas melodias, a alternância inaudita de contraltos e sopranos de sua voz, a melancólica e corrosiva poesia de Brant, Bastos ou Borges - havia sido referência obrigatória para a MPB "de oposição". A arte de Milton também havia refletido e refratado uma certa iconografia católica das Minas Gerais dos carros de boi, igrejas barrocas e ladeiras de paralelepípedos - todos varridos pela modernização, mas preservados como objetos de luto em elegias musicais ${ }^{56}$.

O trecho fala da importância que a produção toma na esfera política, tema sobre o qual discorro no capítulo seguinte. Para o autor, a forma de cantar de Milton traz

${ }^{52}$ Trecho da canção Reis e Rainhas do Maracatu (Tema dos Estudantes do Samba de Três Pontas), de Milton Nacimento, Novelli, Nelson Angelo e Fran, álbum Clube da Esquina 2, 1978.

${ }^{53}$ Trecho da canção A Sede do Peixe (Para o que não tem solução), de Milton Nascimento e Márcio Borges, álbum Clube da Esquina 2, 1978.

${ }^{54}$ COELHO, Rafael Senra. Dois lados da mesma viagem: A Mineiridade e o Clube da Esquina. Dissertação de Mestrado. Promel - UFSJ: São João del-Rei, 2010, p. 64.

${ }^{55}$ NASCIMENTO, Milton. Milton: $O$ dono da voz. Entrevista. In: Revista Bizz. São Paulo: Ed. 023, junho de 1987, p. 68.

56 AVELAR, Idelber. De Milton ao Metal: Política e Música em Minas. Disponível em: http://www.hist.puc.cl/iaspm/rio/Anais2004\%20\%28PDF\%29/IdelberAvelar.pdf. 
uma postura política por ser uma novidade, por ser diferente. Por outro lado, mais uma vez é destacada a valorização de elementos tradicionais com a qual essa música opera.

No Clube da Esquina, o rebuscamento do Barroco mineiro, a leveza do "iê-iê-iêe", a atitude do rock e a força da música regional convivem e formam uma nova estética musical que influencia muitos músicos até hoje. Sobre essa inovação musical, atribuída principalmente à forma de compor de Milton, Márcio Borges afirma que está ligada ao universo mineiro e belo-horizontino.

Para mim, a música de Bituca revelava sua qualidade única. Seu som tinha uma força emotiva admirável. A vida de Minas, a circunspecção do nosso povo, a herança cultural do interior, o ritmo polidividido do "Vera Cruz" deslizando sobre trilhos, em compassos complexos, tal como tantas vezes eu e ele ouvíramos naquela areazinha que existe atrás dos vagões de passageiros, tantas vezes fomos ao Rio de trem, tudo se encontrava e entornava na voz bailarina e no violão pontilhado do meu bom Vituperatus, o nobre Ludwig Von Betúcious. Para o mercado americano, acostumado a pôr um rótulo debaixo de cada produto - jazz, rock, fusion, country -, Bituca iria representar um desafio. Poderiam chamá-lo simplesmente Milton ${ }^{57}$.

Quanto às misturas feitas entre temas tradicionais e modernos na música do Clube da Esquina, creio que podem ser entendidas como características barrocas.

Nesse sentido é possível entender a produção musical analisada operando com o conceito de Barroco como definido por Rubem Barboza Filho ${ }^{58}$.

Segundo o autor, trata-se da tentativa de renovação da percepção do mundo, que era pelo sentido religioso e passa a se distanciar da questão divina, uma reação à Revolução Científica. Esse sentido religioso realizava naturalmente a transformação do que é particular em público, como um modo de fortalecer a vida pública. Essa transformação passa a ser construída de maneira artificial, pela figura do príncipe. Ou seja, a sociedade continua a transformar em públicos aspectos particulares, mas de uma forma diferente da feita antes. Então o Barroco,

\footnotetext{
${ }^{57}$ BORGES, Márcio. Os sonhos não envelhecem: Histórias do Clube da Esquina. São Paulo: Geração Editorial, 2009, p. 175.

58 BARBOZA FILHO, Rubem. Tradição e Artifício - Iberismo e Barroco na Formação Americana. Belo Horizonte: Ed. UFMG; Rio de Janeiro: IUPERJ, 2000.
} 
para Barboza, denota a capacidade de mudar permanecendo o mesmo. Para ele, essa é uma herança ibérica que se tornou característica brasileira.

Heloísa Starling aponta para a ligação do conceito do autor com a música do Clube da Esquina, mostrando como nesta estão presentes:

o súbito distanciamento do sagrado impondo à nossa subjetividade humana a tarefa de reconstruir de baixo para cima a ordem fragmentada e partida do mundo; o desejo de reconstrução da harmonia aparentemente perdida com o transcendente; a veemência trágica; a visão angustiante da evanescência de significados; a contínua inquietação espiritual e sensorial; o tema da vontade política como motor de organização da vida comum dos homens; o conhecimento pela alegoria. Dito de outra forma: o iberismo, nas canções do Clube da Esquina, vem diretamente impregnado pelo espírito do Barroco $^{59}$.

Nas músicas de estética inovadora da produção analisada, além das melodias e harmonias que lembram músicas religiosas, os autores falam em procissões, igrejas, divino e usam outros aspectos que estabelecem esse reconhecimento da tradição, como o congado mineiro e o samba e, portanto, de uma unidade ou semelhança entre os ouvintes. É mais uma vez o moderno e o tradicional convivendo, uma música que inova usando a tradição, que transforma e mantém simultaneamente.

O conceito utilizado por Barboza liga-se às características do Barroco como estética pelo nexo entre arte e religião que apresenta, tão marcante também na música do Clube da Esquina, pelo sincretismo brasileiro que permite reconhecer plasticamente e principalmente pela forma como apresentou uma "solução brasileira" para uma influência portuguesa. Ou seja, manteve uma tradição modificando-a a seu modo, não só nacionalmente como também regionalmente, já que o Barroco de Minas possui características diferentes de outros desenvolvidos no Brasil ${ }^{60}$, como afirma Fernanda Arêas Peixoto.

Mas o Brasil, não conheceu um só barroco, mostra [Roger] Bastide. Às civilizações opostas do Nordeste e de Minas corresponderam diferentes estilos barrocos. $\mathrm{Na}$ sociedade

${ }^{59}$ STARLING, H. Coração americano; panfletos e canções do Clube da Esquina. In: MOTTA, R. (ORG.). O golpe e a ditadura militar 40 anos depois (1964-2004). São Paulo: Edusc, 2004, p. 6.

${ }^{60}$ PEIXOTO, Fernanda Arêas. Diálogos Brasileiros: Uma análise da Obra de Roger Bastide. São Paulo: Editora da Universidade de São Paulo, 2000. 
dispersa do Nordeste, a igreja funciona como centro unificador das famílias patriarcais, definindo-se por essa razão como uma igreja de sacristias. Em Minas, a igreja reflete as disputas das confrarias e a estrutura de uma sociedade urbana, com luta de classes e de camadas sociais: brancos contra mulatos, mulatos contra negros, nacionais contra portugueses etc. Por isso, temos aí uma igreja de confrarias, de festas religiosas e procissões ${ }^{61}$.

Segundo Roger Bastide,

A sociedade do Nordeste é centrífuga, ganglionar, rural, centrada no engenho da cana-de-açúcar e na autoridade independente do patriarca; a sociedade de Minas, no final da época da mineração, é uma sociedade centrípeta, urbana, favorecendo a disseminação de um espírito novo, contestatório, como o que vai estruturar a Independência. Ora, a diferença dessas duas estruturas sociais confere à Igreja funções diferentes e deixa marcas diversas na estrutura arquitetônica ${ }^{62}$.

A reflexão acima mostra características importantes do desenvolvimento do Barroco em Minas que estão relacionadas com o modo como o tema está na música do Clube da Esquina. A contestação e a busca pela novidade são questões que analiso aqui, além do fato de que o Barroco desenvolvido na região tornou-se muito característico de Minas, uma referência importante desse Estado. Por isso, a presença do Barroco na música do grupo é mais uma forma de valorizar a história e a cultura locais. Além dos exemplos já citados como ligados à estética barroca na produção musical, há uma citação direta a Aleijadinho, principal artista do movimento, na música A Sede do Peixe (Para o que não tem solução).

Para o que o suor não me deu/ O fogo do amor ensinou/ Ser o barro embaixo do sol/ Ser chuva lavrando o sertão/ qual Aleijadinho de Sabará ${ }^{63}$

Sobre o artista, Peixoto afirma:

A obra do Aleijadinho exemplifica esse processo de constituição de uma arte genuinamente nacional: a nossa solução é a do mulato, capaz de transformar a herança lusitana.

\footnotetext{
${ }^{61}$ Idem, p. 65.

${ }^{62}$ BASTIDE, Roger. Imagens do Nordeste Místico em Branco e Preto apud PEIXOTO, Fernanda Arêas. Diálogos Brasileiros: Uma análise da Obra de Roger Bastide. São Paulo: Editora da Universidade de São Paulo, 2000, P. 65.

${ }^{63}$ Trecho da canção A Sede do Peixe (Para o que não tem solução), de Milton Nascimento e Márcio Borges, álbum Clube da Esquina 2, 1978.
} 
A nossa originalidade está dada, então, pela mistura de civilizações, pela mestiçagem racial, cultural, estética ${ }^{64}$.

Preocupado com a questão da autenticidade da arte no Brasil e envolvido com a ideia modernista de transformação das heranças culturais, de antropofagia, Bastide aponta aí para a diversidade de referências presentes na obra de Aleijadinho, o que se mostra fundamental também neste trabalho para entender o Clube da Esquina. Para Peixoto, as afinidades de Bastide com o Barroco vêm do "gosto pela forma retorcida da arquitetura barroca que, segundo ele, apela ao sonho, ao imaginário ${ }^{65,}$. Essa atmosfera onírica é muito presente na poética do Clube da Esquina, em que os "sonhos não envelhecem $66 "$ e regem muitas das cenas cantadas por eles.

Com sol e chuva/ você sonhava que ia ser melhor depois/ você queria ser o grande herói das estradas/ tudo que você queria $\operatorname{ser}^{67}$

Invento o mar/ Invento em mim o sonhador ${ }^{68}$

O que vocês fariam pra sair dessa maré?/ o que era sonho vira terra/ quem vai ser o primeiro a me responder? ${ }^{69}$

Coração americano/ acordei de um sonho estranho ${ }^{70}$

Alguém que vi de passagem/ Numa cidade estrangeira/ Lembrou os sonhos que eu tinha/ $\mathrm{E}$ esqueci sobre a mesa/ Como uma pera se esquece/ Dormindo numa fruteira ${ }^{71}$

\footnotetext{
${ }^{64}$ PEIXOTO, Fernanda Arêas. Diálogos Brasileiros: Uma análise da Obra de Roger Bastide. São Paulo: Editora da Universidade de São Paulo, 2000, p. 67.

${ }^{65}$ Idem, p. 68.

${ }^{66}$ Trecho da canção Clube da Esquina n⿳2, de Milton Nascimento, Lô Borges e Márcio Borges, gravada no álbum Clube da Esquina, de 1972, ainda sem letra. A canção só recebeu a letra de Márcio Borges alguns anos depois a pedido de Nana Caymmi.

${ }^{67}$ Trecho da canção Tudo que você podia ser, de Lô Borges e Márcio Borges, álbum Clube da Esquina, 1972.

${ }^{68}$ Trecho da canção Cais, de Milton Nascimento e Ronaldo Bastos, álbum Clube da Esquina, 1972.

${ }^{69}$ Trecho da canção Saídas e Bandeiras $\mathbf{n}^{\mathbf{0} 1}$, de Milton Nascimento e Fernando Brant, álbum Clube da Esquina, 1972.

${ }^{70}$ Trecho da canção San Vicente, de Milton Nascimento e Fernando Brant, álbum Clube da Esquina, 1972.

${ }^{71}$ Trecho da canção Um Gosto de Sol, de Milton Nascimento e Ronaldo Bastos, álbum Clube da Esquina, 1972.
} 
Quero estar onde estão/ os sonhos desse hotel/ muito além do céu $^{72}$

Um pé de moleque e um rabo de saia, um serão/ As sombras da praia e o sonho na esteira/ Uma alucinação ${ }^{73}$

É preciso ter sonho sempre ${ }^{74}$

Haroldo de Campos trata em uma de suas obras ${ }^{75}$ do Barroco como um estilo de extremos e contradições e faz uma crítica à tese de Antonio Candido, que minimiza a importância do movimento na formação literária brasileira. Campos afirma que o que ele chama de "sequestro do barroco" é efeito do modelo semiológico articulado por Candido, que confere à literatura como tal as características peculiares ao projeto literário do Romantismo ontológiconacionalista:

Modelo que enfatiza o aspecto "comunicacional" e "integrativo" da atividade literária, tal como este se teria manifestado na peculiar síntese brasileira de classicismo e romantismo, da qual emerge uma "literatura empenhada", com "sentimento de missão" em grau tão elevado que chegava, por vezes, a tolher o "exercício da fantasia" (...) ${ }^{76}$.

Ou seja, o Barroco é excluído justamente por suas características que o distanciam dos estilos que têm a nação como tema, por sua especificidade em cada região em que se desenvolveu, o que corrobora para a analogia entre a música do Clube da Esquina e o Barroco.

Sobre a convivência paradoxal entre diversos temas, ela é, nas palavras de Octavio Paz, característica da modernidade.

A tradição do moderno encerra um paradoxo maior do que o que deixa entrever a contradição entre o antigo e o novo, o moderno e o tradicional. A oposição entre o passado literalmente se evapora, pois o tempo transcorre com tal

\footnotetext{
${ }^{72}$ Trecho da canção Trem de Doido, de Lô Borges e Márcio Borges, álbum Clube da Esquina, 1972.

${ }^{73}$ Trecho da canção Léo, de Milton Nascimento e Chico Buarque de Hollanda, álbum Clube da Esquina 2, 1978.

${ }^{74}$ Trecho da canção Maria Maria, de Milton Nascimento e Fernando Brant, álbum Clube da Esquina 2, 1978.

${ }^{75}$ CAMPOS, Haroldo de. O Sequestro do Barroco na Formação da Literatura Brasileira: O Caso Gregório de Mattos. São Paulo: Ilumiuras, 2011.

${ }^{76}$ Idem, p. 40.
} 
celeridade, que as distinções entre os diversos tempos passado, presente, futuro - apagam-se ou pelo menos se tornam instantâneas, imperceptíveis e insignificantes ${ }^{77}$. (...) A estética da mudança não é menos ilusória que a da imitação dos antigos. Uma tende a minimizar as mudanças, a outra a exagerá-las ${ }^{78}$.

O autor traz outra colocação muito importante para pensar o Clube da Esquina e que permite uma comparação interessante com uma fala de Márcio Borges. Paz diz que a modernidade cultua a juventude e seus valores como uma superstição, o que gera um envelhecimento precoce. Falando sobre a poesia moderna, ele afirma que seu fundamento é "a ideia de mudança, mais do que as próprias mudanças", que "a arte de hoje deve ser diferente da arte de ontem" ${ }^{79}$ ". Para o autor, "nossas coleções de arte, nossas antologias de poesia e nossas bibliotecas estão cheias de estilos, movimentos, quadros, esculturas, romances e poemas prematuramente envelhecidos $^{80,}$.

Já Márcio conta que "leu em algum lugar que na década de 1960 mais da metade da humanidade estava entre os 18 e 25 anos de idade; era predominantemente

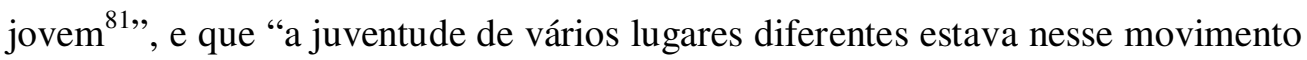
de querer mudar a ordem, buscando mudanças ${ }^{82}$ ". Essa afirmação de Márcio não precisa ter sua veracidade confirmada, pois o que importa nela é justamente essa valorização da juventude de que fala Paz por parte de um jovem da época, a crença de um indivíduo e de um grupo nessa exaltação. Quando ele afirma que "Na nossa música, eu e Bituca buscávamos mais a originalidade do que a beleza ${ }^{83}$, reforça a ideia da mudança, do original, como valor supremo.

E sobre o envelhecimento precoce das manifestações artísticas de que fala Paz, considero significativo pensar na construção do Museu do Clube da Esquina por seus próprios integrantes, o que também não é um discurso de unanimidade entre

${ }^{77}$ PAZ, Octavio. Os Filhos do Barro: do romantismo à vanguarda. Rio de Janeiro: Nova Fronteira, 1984, p. 22.

${ }^{78}$ Idem, p. 201.

${ }^{79}$ Idem, p. 198 .

${ }^{80}$ Idem, p.22.

${ }^{81}$ Márcio Borges em entrevista concedida à esta pesquisa.

${ }^{82}$ Idem.

${ }^{83}$ Idem. 
eles. Se Márcio Borges é o idealizador do museu, para Nelson Angelo, por exemplo, há um estranhamento sobre essa questão. "Eu nunca quis virar museu. Estou vivo. Estamos vivos e atuando. Dei meu depoimento lá porque é importante ter essas histórias guardadas, mas não como museu ${ }^{84,}$.

Idelber Avelar traz uma análise importante sobre a ligação da música do Clube da Esquina com a juventude mineira que se articula com as falas de Márcio Borges e Nelson Angelo. Para o autor, o grupo é um

(...) conglomerado musical que chegou ao centro da MPB e representou, para nós mineiros, o horizonte a partir do qual se avaliaria toda a música nacional jovem, popular e de bom gosto. Mas "popular", "juventude", "nação" e "bom gosto" são termos de história bastante acidentada, que sofrem transformações ao longo da carreira de Milton. Estas só são compreensíveis quando articuladas com alguns processos contemporâneos entre si: a campanha das diretas, a "tancredização" do Clube da Esquina e o rosnar das guitarras do heavy metal, oriundas de outra rua em Santa Teresa ${ }^{85}$.

O autor mostra como uma produção musical que inicialmente foi apropriada pela juventude acabou perdendo esse sentido para uma outra geração. Não pretendo explorar densamente o tema já que escapa ao período dos discos pesquisados. No entanto, é uma questão que deve ser citada por estar relacionada à institucionalização desta produção, ponto criticado por alguns integrantes ao qual retorno algumas vezes no trabalho.

Avelar conclui comparando o Clube da Esquina ao Sepultura, grupo de heavy metal também nascido em Minas Gerais, nos anos 1980, cuja emergência coincide com a "exaustão de um modelo emepebista de formulação da relação entre música e cidadania ${ }^{86 "}$ e tem um diálogo maior com a juventude de sua época.

Em contrapartida à ideia de juventude, a análise de Helena Bomeny sobre o hábito belo-horizontino da confraria, que nasce com os modernistas mineiros nos anos 1920, traz revelação importante sobre a forma como se dava o diálogo entre gerações na cidade.

\footnotetext{
${ }^{84}$ Nelson Angelo em entrevista concedida à esta pesquisa.

${ }^{85}$ AVELAR, Idelber. De Milton ao Metal: Política e Música em Minas. Disponível em: http://www.hist.puc.cl/iaspm/rio/Anais2004\%20\%28PDF\%29/IdelberAvelar.pdf.

${ }^{86}$ Idem.
} 
A geração dos anos 20 teria na confraria um hábito muito cultivado. Contos, crônicas, cartas, memorialística, tudo isso confirma com sinal positivo os ganhos e o prazer com que os intelectuais sorviam aqueles encontros rotineiros que se instituíram como instantes sagrados. O gosto pela confraria fez escola, e atravessou outras décadas, tendo agora outros intelectuais como centro de referência. Continuaria a tradição do encontro, embora tivesse arrefecido o movimento de vinda dos intelectuais para a política. Belo Horizonte dos anos 1950 continuou sendo lembrada como palco de encontro dos mais velhos com os mais novos na crônica de Silviano Santiago. "Na época", escreve ele, "JK era o governador das Gerais. Os mais velhos foram professores numa mesa de confeitaria (...) Ao transgredirem as regras clássicas do ensino pequeno-burguês, os mais velhos incentivavam os mais novos a transgredirem as idéias convencionais e retrógradas da sociedade mineira ${ }^{87, "}$. O hábito da conversa nos bares, nas livrarias e confeitarias atravessou décadas e se enraizou como ritual e cultivo da atividade dos intelectuais mineiros da cidade dos modernistas da década de $1920^{88}$.

Mesmo com a valorização da juventude citada por Márcio Borges, é interessante ver como os jovens do Clube da Esquina trabalham com memórias locais e com a tradição, recorrendo inclusive a Carlos Drummond de Andrade, um dos modernistas da geração citada por Bomeny, e mantêm essa cultura do encontro e da tentativa de transgredir o que a autora chama de "ideias convencionais e retrógradas da sociedade mineira", que Márcio caracteriza como provincianismo.

Vamos caminhando pelas ruas de nossa cidade/ Viver derramando a juventude pelos corações ${ }^{89}$

Fernando Brant afirma que "Minas tem essas características múltiplas: é conservadora e progressista, nela vivem a posição, a oposição e a síntese. Mas isso eu sei é hoje ${ }^{90 "}$, explicitando a convivência de opostos na cultura de Minas Gerais. Com a frase "Mas isso eu sei é hoje", ele quer dizer que no momento de produção da obra musical analisada, não havia a consciência por parte dele de estar trabalhando com características mineiras.

\footnotetext{
${ }^{87}$ Silviano Santiago, "De passarinhos e formiguinhas". Jornal do Brasil, sábado, 20 de março de 1999.

${ }^{88}$ BOMENY, Helena. Infidelidades eletivas: intelectuais e política. In: CONSTELAÇÃO Capanema: intelectuais e política/ Helena Bomeny (Org.). Rio de Janeiro: Ed. Fundação Getulio Vargas; Bragança Paulista(SP): Ed. Universidade de São Francisco, 2001, p.16.

${ }^{89}$ Trecho da canção Credo, de Milton Nascimento e Fernando Brant, álbum Clube da Esquina 2, 1978.

${ }^{90}$ COELHO, Rafael Senra. Dois lados da mesma viagem: A Mineiridade e o Clube da Esquina. Dissertação de Mestrado. Promel - UFSJ: São João del-Rei, 2010, p.13.
} 
As falas dos integrantes do grupo frequentemente tratam de algumas questões que marcam a música do Clube da Esquina e de muitas outras de maneira naturalizada, o que é esperável, já que elas fazem parte de suas culturas e o distanciamento nesse caso é mais difícil. No entanto, é preciso desconfiar dessa naturalidade, pois creio ser possível dizer que existe sim um esforço em fazer uma música mineira, em deixar essa identidade marcada, assim como há um empenho em conectá-la com temas mais universais, como veremos adiante.

Para Ruben Oliven ${ }^{91}$, o regionalismo é simplesmente um caso particular de lutas propriamente simbólicas em que os agentes estão identificados territorialmente contra um ou muitos mecanismos do Estado-Nação e que tem como objetivo a conservação ou a transformação das relações de forças simbólicas. Não acredito que o Clube da Esquina tome uma posição contra o país. Ele trata também de temas brasileiros (o contexto da ditadura militar é um deles), mas vejo nessa música uma vontade de afirmar sua particularidade enquanto mineira, enquanto fora do eixo Rio - São Paulo - Bahia, tão forte na história da música brasileira. E essa diferenciação pode funcionar não no sentido contrário à ideia de nação, como é próprio dos movimentos regionalistas segundo Oliven, mas como constituinte dessa ideia, já que o Brasil tem uma identidade fortemente embasada na diversidade, fenômeno para o qual o autor também aponta.

Também estão surgindo culturas híbridas. Antigamente as culturas tendiam a ser associadas a um território e a identidades definidas. O que se verifica atualmente é um cruzamento das fronteiras culturais e simbólicas que faz com que haja uma desterritorialização dos fenômenos culturais. (...) Todo esse processo de mundialização da cultura, que dá a impressão de que vivemos numa aldeia global, acaba repondo a questão da tradição, da nação e da região. Á medida em que o mundo se torna mais complexo e se internacionaliza, a questão das diferenças se recoloca e há um intenso processo de construção de identidades ${ }^{92}$.

Pelas questões analisadas, considero ser possível sugerir a existência da "mineiridade" na música do Clube da Esquina, se entendemos essa identidade mineira como a convivência harmônica entre temas opostos, entre a tradição e a

\footnotetext{
${ }^{91}$ OLIVEN, Ruben George. A parte e o todo: A Diversidade Cultural no Brasil-Nação. Petrópolis: Vozes, 1992, p. 19.

${ }^{92}$ Idem, p.135.
} 
modernidade, o rural e o urbano, o Barroco e a sociedade industrial, a forte influência da religião e a crítica a ela, entre tantos outros.

Alceu Amoroso Lima conceituou a mineiridade de uma forma que acabou se tornando clássica. Segundo o autor, as categorias fundamentais do que é ser mineiro são "compensação, equilíbrio e moderação". O ponto, para Lima, "tratase de ser fiel à sua própria natureza em qualquer estágio do progresso. Pode-se ser moderno numa casa de taipa e eterno num arranha-céu ${ }^{93}$ ".

Portanto, se muitos percebem a "mineiridade" como característica marcante dessa música, entendo que a ideia do que é ser mineiro nesse caso vem dessa mineiridade clássica, entendida como equilíbrio e compensação, características com as quais o Clube da Esquina acaba operando ao misturar de maneira harmônica referências tão diversas, vindas de terras bem distantes das Minas Gerais.

\subsection{O Clube da Esquina e a articulação entre o local e o global}

Se os ouvintes e certa parte da crítica tocam sempre na questão da mineiridade da música do Clube da Esquina, em minhas conversas com alguns integrantes do grupo a escolha pelo que é universal pareceu muito mais pensada. Algumas vezes pude perceber um certo incômodo com a rotulação de sua obra como mineira. Para Ronaldo Bastos, a ligação com Minas virou algo "institucional", o "Clube ficou acomodado sob esse ponto de vista". "Não tenho nenhum problema com a mineiridade. Ela está lá, mas não pensávamos nisso. Tínhamos muito mais uma visão universal ${ }^{94, "}$. Fernando Brant chama a atenção para a mesma questão: “'Sou do mundo, sou Minas Gerais ${ }^{95}$,... mas pode ver que o mundo vem primeiro ${ }^{96, "}$. Segundo Rafael Senra Coelho,

\footnotetext{
${ }^{93}$ BOMENY, Helena. Guardiães da razão: modernistas mineiros. Rio de Janeiro: Editora UFRJ/ Tempo Brasileiro, 1994, p. 19.

${ }^{94}$ Ronaldo Bastos em entrevista concedida para esta pesquisa.

${ }^{95}$ Trecho da canção Para Lennon a McCartney, de Lô Borges, Márcio Borges e Fernando Brant, álbum Milton, 1970.
} 
Umas das frases mais emblemáticas da mineiridade cunhadas nas canções do movimento é clara: "sou do mundo, sou Minas Gerais". O caráter universal e, ao mesmo tempo, regional das letras das músicas, agregados às influências mais diversas das composições e arranjos das mesmas, revelam um intenso cosmopolitismo que paradoxalmente exalta o estado natal do grupo $^{97}$.

Nesse sentido, acredito ser possível ver o Clube da Esquina como uma antecipação do fenômeno que ganhou reconhecimento com o Manguebeat ${ }^{98}$, ou seja, a articulação entre o local e o global. Carlos Sandroni analisa o movimento recifense e o momento em que surge afirmando que foi um período em que o poder público e o mercado musical se voltaram para músicas vistas como portadoras de marcas de "ancestralidade cultural" ou "tradição".

Tais circuitos, no entanto, se distinguem pela maneira como articulam o "local" e o "global" daqueles ligados à consagração no mercado nacional com passagem pelo eixo Rio-São Paulo e sob a égide da MPB - ainda, em parte, vigentes, mas com menos exclusividade do que tinham até a década de $1980^{99}$.

Ou seja, por operar com elementos que trazem uma ideia de regionalidade e, como veremos nesse capítulo, com questões de esfera global, o Clube da Esquina diferencia-se do que o autor denomina como "circuitos consagrados da MPB". A produção analisada é contemporânea a esses fenômenos e anterior ao Manguebeat, mas está mais próxima deste se considerarmos a cena a qual se refere.

Também é possível fazer uma comparação entre o Clube da Esquina e a bossa nova. Ouvi de alguns integrantes a ideia de uma ligação direta entre os dois fenômenos, no sentido não só da incorporação de referências musicais estrangeiras, mas também pela fama internacional que obteve.

Para Flávio Venturini, "Um diferencial é que o Clube da Esquina foi a primeira música com um cunho universal depois da bossa nova ${ }^{100}$. Ronaldo Bastos

\footnotetext{
${ }^{96}$ Fernando Brant em entrevista concedida para esta pesquisa.

${ }^{97}$ COELHO, Rafael Senra. Dois lados da mesma viagem: A Mineiridade e o Clube da Esquina. Dissertação de Mestrado. Promel - UFSJ: São João del-Rei, 2010, p. 31.

${ }^{98}$ Movimento musical surgido na cidade do Recife no inicio dos anos 90.

99 SANDRONI, Carlos. O mangue e o mundo: notas sobre a globalização musical em Pernambuco. Claves, CCHLA - UFPB, p. 63 a 70.

${ }^{100}$ Flávio Venturini em depoimento concedido a esta pesquisa.
} 
corrobora com essa ideia afirmando que "qualquer pessoa intelectualmente de boa vontade, mesmo os mais renitentes darks de butique, vai enxergar muito além de mineiro o que foi, a partir da Bossa Nova, o mais universalista movimento musical brasileiro ${ }^{101,}$.

O reconhecimento internacional da música do Clube da Esquina e de Milton Nascimento é realmente grande. Entretanto, entendo que dita pelos músicos do grupo, essa fala mostra uma marcação de posição, uma tentativa de valorização desse fenômeno musical, principalmente como uma crítica ao fato de a tropicália ter mais espaço na mídia e nos estudos acadêmicos brasileiros mesmo não tendo, segundo essas fontes, uma grande repercussão no exterior. Digo isso porque essas frases apareceram diversas vezes como uma comparação com o movimento tropicalista. Acredito que seja também uma tentativa de afirmar o Clube da Esquina como movimento cultural, o que é importante para alguns integrantes.

O refrão de Para Lennon e McCartney explicita essa ideia, e além dele outros elementos constituintes da música do Clube da Esquina são importantes para entender a valorização do global, a forma como a preocupação em ser universal foi transformada em música. Cabe aqui dizer que a primeira vez que olhei para o Clube da Esquina não apenas como ouvinte, mas como pesquisadora, foi ao presenciar esse mesmo refrão, "sou do mundo, sou Minas Gerais", sendo cantado com entusiasmo pela plateia carioca de um show de Lô Borges na extinta loja de discos Modern Sound. A surpresa e a emoção que surgiram com aquela identificação do público com a canção me chamaram a atenção para o quanto essa música era mais do que "mineira”. E fazê-la universal era uma preocupação muito presente na fala dos integrantes, que "fugiam do provincianismo ${ }^{102}$ ".

A fuga do provincianismo é uma questão histórica, citada por Bomeny ao tratar da aproximação da primeira geração de modernistas com o poder no estado de Minas Gerais durante o governo do ministro Capanema. A autora afirma que esses

\footnotetext{
${ }^{101}$ BASTOS, Ronaldo. Os Beatles eram Rolling Stones. Disponível no site do Museu do Clube da Esquina: http://www.museuclubedaesquina.org.br/blog/ponto-dos-musicos/os-beatles-eramrolling-stones/

102 Márcio Borges em entrevista concedida para esta pesquisa.
} 
intelectuais percebiam uma distância entre suas expectativas e o cerco que Belo Horizonte, a nova capital, ainda com ares de arraial, lhes impunha.

O esforço de se apresentarem como membros de um ideal de unidade, moderação, prudência e equilíbrio - valores expressos no ideário da mineiridade - correspondia ao esforço de criarem uma imagem de capital, centro cultural e locus político capaz de influir nos destinos do estado de Minas Gerais. Os trajetos de Pedro Nava e Drummond simbolizam o trajeto de toda uma geração que, talvez, seja emblemática do insucesso de transformar a Belo Horizonte dos anos 20 na capital cultural, cosmopolita e universalista, como o projeto que o cartesiano Aarão Reis pretendia ${ }^{103}$.

Bomeny explica como começa esse interesse por questões culturais internacionais por parte do grupo estudado por ela.

Belo Horizonte padecia de limites estruturais concretos para a completa realização do ideal individualista. A saída compensadora estava na ultrapassagem das fronteiras locais, pelo exercício intelectual possível, pela formalização e abstração. $\mathrm{O}$ apetite insaciável dos livros, a ansiedade pelas novidades literárias francesas, vindas do grande centro difusor da cultura ocidental, as conversas em torno da criação literária, a liberdade que os diálogos consentiam, tudo isso funcionando como combustível para o deleite e prazer daquele grupo especial de jovens que, em pouco tempo, o país conheceria na vida política nacional ${ }^{104}$.

Em um outro grupo de jovens mineiros, os músicos do Clube da Esquina, é possível ver o mesmo apetite pelas novidades estrangeiras. Além da literatura e filosofia, com o existencialismo francês, por exemplo, eles absorvem influências de outros campos, como o cinema, com a nouvelle-vague francesa, que não coincidentemente tinha na juventude de seus cineastas um ponto diferencial, e a música, com o jazz norte-americano, o rock progressivo, Beatles e Rolling Stones e a música hispânica. Esses fenômenos artísticos, entre outros, faziam parte do gosto dos integrantes do grupo e se tornaram referências para a música produzida por eles.

Se na modernidade as culturas e identidades nacionais dominam, se sobrepõem sobre o que é mais particularista ou local, na pós-modernidade, com a

${ }^{103}$ BOMENY, Helena. Infidelidades eletivas: intelectuais e política. In: CONSTELAÇ̃̃O Capanema: intelectuais e política/ Helena Bomeny (Org.). Rio de Janeiro: Ed. Fundação Getulio Vargas; Bragança Paulista(SP): Ed. Universidade de São Francisco, 2001, p.13.

${ }^{104}$ Idem, p. 14. 
globalização, elas ainda têm força, mas começam a ser enfraquecidas pela valorização das identidades locais e regionais ${ }^{105}$. Essa visão defendida por autores como Stuart Hall e Ruben Oliven, como vimos há pouco, aparece aqui como princípio de investigação da música do Clube da Esquina. Acredito que tanto melódica quanto tematicamente as canções do grupo tratam de elementos locais que se articulam ao global, têm uma marca "mineira", como vimos, e influências "universais".

Liv Sovik, falando de um cenário mais novo (2009), traz uma tese importante para entender a forma como se dá essa volta para o local e a dissolução do nacional no campo musical:

Os porta-vozes novos da cultura nacional musical são rappers e funkeiros, pessoas para quem o imaginário do caleidoscópio ou alegoria ou descanonização ou carnavalização ou até ironia não são centrais, como são para o tropicalismo e seus diversos seguidores. Sua inserção nas hierarquias norte-sul passa, antes disso, pelo seu próprio poder cultural local e o lugar que ocupam na diáspora africana. Mesmo assim, há rappers, como Marcelo D2, B Negão e Rappin'Hood, que se defendem da pecha da desnacionalização. A defesa não passa pelo ecletismo e a alegoria nacional, como no tropicalismo, mas pela incorporação de um elemento cujo sentido está mais estabilizado ainda, o samba. Diante da nova situação, alguns movimentos de classe média abrem mão da ambição global e recuam para a cultura local, como é o caso da renovada promoção do samba "de raiz", um movimento cultural carioca, da indústria cultural da Lapa, antes de brasileiro ${ }^{106}$.

Podemos dizer que o Clube da Esquina é, de certa forma, uma antecipação desse cenário, por realizar esse recuo para a cultura local, operando não com o samba "de raiz", que tens suas origens ligadas à história do Rio de Janeiro, mas com a "harmonia mineira", que como explica Tavinho Moura, tem a melodia e a própria harmonização mais elaboradas do que o ritmo, características pelas quais se difere do samba. Já uma diferença pontual entre a produção musical analisada neste trabalho e a estudada pela autora é, justamente, o abrir mão do global.

Will Straw diferencia "comunidade" e "cena musical". O autor afirma que o conceito de comunidade musical é mais antigo e pressupõe a existência de uma

\footnotetext{
${ }^{105}$ HALL, Stuart. A identidade cultural na pós-modernidade. Rio de Janeiro: DP\&A, 2002.

${ }^{106}$ SOVIK, Liv. Aqui ninguém é branco. Rio de Janeiro: Aeroplano, p. 111.
} 
população cuja produção seja relativamente estável e explore um ou mais idiomas musicais constituídos dentro de um legado histórico que é geograficamente específico, ou seja, há uma continuidade entre presente e passado. $\mathrm{O}$ conceito de cena se aproveita da comunidade ao reinventar tradições e origens, pois na cena coexistem práticas musicais que interagem com vários processos de diferenciação. A sugestão do autor de como lidar com os espaços culturais foi fundamental para este trabalho.

\begin{abstract}
At one level, this distinction simply concretizes two countervailing pressures within spaces of musical activity: one towards the stabilization of local historical continuities, and another which works to disrupt such continuities, to cosmopolitanize and relativize them. Clearly, the point is not that of designating particular cultural spaces as one or the other, but of examining the ways in which particular musical practices 'work' to produce a sense of community within the conditions of metropolitan music scenes ${ }^{107}$.
\end{abstract}

Assim, percebo como a música do Clube da Esquina, que entendo como uma cena musical, e não uma comunidade, realiza essa articulação entre características geograficamente localizadas e aspectos que sofrem influências variadas, como os espaços se moldam de acordo com as possibilidades de alianças entre estilos musicais e vínculos afetivos entre lugares geográficos dispersos ${ }^{108}$. Na música do grupo há essa coexistência de práticas musicais diferentes, que se articulam construindo uma forma musical inovadora, em que a diversidade (das referências e influências) se torna um valor importante, como discuto em breve.

Segundo Néstor García Canclini ${ }^{109}$, se pensarmos em aspectos econômicos, políticos, culturais e comunicacionais, é possível dizer que a data de início do fenômeno da globalização foi em meados do século XX. Como o objeto estudado está inserido historicamente nesse período, investigo aqui se esta música está dialogando com as tendências de sua época ou desconectada delas, focando no ponto sobre a articulação entre o local e o global e a dissolução da identidade nacional.

\footnotetext{
${ }^{107}$ STRAW, Will. Comunities and scenes in popular music. In: GELDER, Ken e THORNTON, Sarah (org.). The Subcultures Reader. London and New York: Routledge, 1997, p. 494.

${ }^{108}$ Idem, p. 504.

${ }^{109}$ CANCLINI, Néstor García. A Globalização Imaginada. São Paulo: Iluminuras, 2007, p. 41.
} 
Hall explica o enfraquecimento das nacionalidades como efeito desse processo afirmando haver evidências de "um afrouxamento de fortes identificações com a cultura nacional, e um reforçamento de outros laços e lealdades culturais, 'acima' e 'abaixo' do nível do estado-nação ${ }^{110,}$.

As identidades nacionais permanecem fortes, especialmente com respeito a coisas como direitos legais e de cidadania, mas as identidades locais, regionais e comunitárias têm se tornado mais importantes. (...) Elas apresentam o que algumas vezes é chamado de uma forma particularista de vínculo ou pertencimento. Sempre houve uma tensão entre essas identificações mais universalistas - por exemplo, uma identificação maior com a humanidade do que com a "inglesidade" (englishness). Esta tensão continuou a existir ao longo da modernidade: o crescimento dos estados-nação, das economias nacionais e das culturas nacionais continuam a dar um foco para a primeira; a expansão do mercado mundial e da modernidade como um sistema global davam o foco para a segunda. ${ }^{111}$

Para Otávio Velho ${ }^{112}$, os processos através dos quais o mundo se torna um único "lugar" ganham tal proeminência que torna-se possível dizer que a globalização é atualmente pano de fundo incontornável tanto dos processos socioculturais quanto da reflexão sobre eles, a ponto de provocar uma aproximação inusitada entre "sujeitos" e "objetos", bem como uma relativização de boa parte das antinomias aparentemente consagradas, como a que opõe o "local" e o "global".

Acredito que esse fenômeno seja importante para entender o objeto analisado, porque a música do Clube da Esquina tem como um de seus temas o Brasil dos anos 70, principalmente se referindo aos problemas de repressão, censura e violência institucional decorrentes dos anos mais difíceis da ditadura militar que o país vivia, os chamados "anos de chumbo". Posso dizer, portanto, que há algo de caráter nacional presente nessa produção musical.

No entanto, essa questão não é a mais importante nem aquela pela qual esta produção é reconhecida por crítica e público. Como vimos, o que há de "mineiro" está colocado de maneira mais forte e perceptível nessa música do que as questões

\footnotetext{
${ }^{110}$ HALL, Stuart. A identidade cultural na pós-modernidade. Rio de Janeiro: DP\&A, 2002, p. 73.

${ }^{111}$ Idem.

${ }^{112}$ VELHO, Otávio. Besta-Fera: recriação do mundo. Rio de Janeiro: Relume Dumará, 1995, p. 222.
} 
de cultura nacional, e estas são tratadas de uma maneira que pode ser considerada local. Ao mesmo tempo, a identificação com questões globais também está muito presente, tanto na melodia quanto nas letras, e é uma preocupação manifesta dos músicos segundo seus discursos, o que é interessante para pensar também a aproximação entre sujeitos e objetos de que fala Velho.

Os músicos do Clube da Esquina têm uma reflexão muito profunda sobre seu próprio trabalho, tanto que suas falas e classificações surgiram como fontes importantes para este trabalho, em que procurei leva-las em consideração como discursos nativos sem reificá-las. Nesse sentido, uma tese de Velho foi importante como explicação para o papel desses músicos enquanto objetos da minha pesquisa:

Os próprios sujeitos sociais precisam ser repensados, distantes do "ator" enquanto repetidor mecânico de um texto, mas ainda no terreno das metáforas teatrais - semelhantes ao artista que, ao encenar, elabora e reelabora os textos com uma reflexividade que já não pode ser pensada como monopólio de observadores privilegiados e que é capaz, também, de comportar uma plurivocidade, uma coexistência de identidades com graus diversos de compromisso e uma continuidade com os "objetos" que complexificam o campo em que opera ${ }^{113}$ (grifos meus).

O Clube da Esquina reuniu músicos de diversas partes do Brasil, mas além de ser o local de reunião e produção de músicas, Minas Gerais está presente de várias formas nas canções, como vimos anteriormente. Segundo Viveiros Martins, a constituição do grupo se deu, na cidade de Belo Horizonte, pela vivência de experiências coletivas que mostraram àqueles jovens que eles tinham valores em comum sobre os quais era possível falar.

Nas narrativas do Clube, as cidades seriam o local por excelência do viver coletivo, da imaginação que os conduzia a uma infinidade de outros tempos e lugares, sobretudo à possibilidade de conhecer outras pessoas e fazer novas amizades. (...) Cada um de seus integrantes trouxe, com suas referências históricas e culturais particulares, também um pouco de sua cidade natal. Isso fez da capital mineira um solo aglutinador, em torno do qual as cidades de onde partiram tais viajantes - como Três Pontas, Montes Claros, Pedra Azul, Juiz

${ }^{113}$ Idem, p. 225. 
de Fora, Ponte Nova, Caldas, Diamantina, Niterói, entre outras - se avizinhavam pelos caminhos da canção ${ }^{114}$.

O trecho acima traz um diálogo muito interessante com a teoria de Canclini segundo a qual as cidades são os lugares em que se imagina o global.

$\mathrm{Na}$ Europa e nas cidades latino-americanas formadas a partir de modelos europeus, sobretudo espanhóis e portugueses, as cidades cumpriram funções modernizadoras e integradoras dos migrantes, tanto estrangeiros como de diversas regiões do país. Mesmo estabelecendo uma separação entre bairros ricos e pobres, centro e periferia, fomentaram a convivência interétnica. Foi um modo desigual, mas, em geral, menos segregador, de articular o local com o proveniente de outras partes da nação e de outras nações. ${ }^{115}$ (grifos meus)

Se Belo Horizonte se mostra como solo aglutinador das cidades mineiras, faz o mesmo com as referências de outras cidades e países no contexto da globalização. Essas afirmações reforçam a ideia de Straw sobre a troca entre os produtos artísticos e o espaço cultural. Sobre a valorização da cidade como lugar de produção e inspiração artística e essa reunião de referências, alguns trechos de canções são reveladores.

Caminhando pela noite de nossa cidade/ Acendendo a esperança e apagando a escuridão/ Vamos, caminhando pelas ruas de nossa cidade/ Viver derramando a juventude pelos corações/ Tenha fé no nosso povo que ele resiste/ Tenha fé no nosso povo que ele insiste/ $\mathrm{E}$ acordar novo, forte, alegre, cheio de paixão ${ }^{116}$

Guajajaras, Tamoios, Tapuias/ Tubinambás, Aimorés ${ }^{117} /$ Todos no chão/ A cidade plantou no coração/ Tantos nomes de quem morreu/ Horizonte perdido no meio da selva/ Cresceu o arraial/ Arraial $^{118}$

$\mathrm{Na}$ beira do mundo/ portão de ferro, aldeia morta, multidão/ meu povo, meu povo, não quis saber do que é novo, nunca

\footnotetext{
${ }^{114}$ MARTINS, Bruno Viveiros. Som Imaginário: a reinvenção das cidades nas canções do Clube da Esquina. Belo Horizonte: Editora UFMG, 2009, p.45.

${ }^{115}$ CANCLINI, Néstor García. A Globalização Imaginada. São Paulo: Iluminuras, 2007, p. 154.

${ }^{116}$ Trecho da canção Credo, de Milton Nascimento e Fernando Brant, álbum Clube da Esquina 2, 1978.

${ }^{117}$ Os nomes citados são denominações de grupos indígenas e também de ruas da cidade de Belo Horizonte.

${ }^{118}$ Trecho da canção Ruas da Cidade, de Lô Borges e Márcio Borges, álbum Clube da Esquina 2, 1978.
} 
mais/ eh! minha cidade/ aldeia morta, anel de ouro, meu amor/ na beira da vida/ a gente torna a se encontrar só ${ }^{119}$

Bomeny traz informações importantes para entender historicamente essa articulação entre o local e o global na cidade de Belo Horizonte. Em seu trabalho sobre a geração modernista mineira, a autora fala de duas revistas produzidas pelo mesmo grupo que traziam ideias aparentemente opostas.

A Revista e Leite Criôlo são representações típico-ideais do conflito que se estabeleceu na intelectualidade mineira no momento em que pensava a formulação de identidade para o próprio grupo. O primeiro periódico ilustra a tentativa do grupo de se pensar em categorias que extrapolem o regionalismo em direção muito particular, qual seja, na adesão de códigos de conduta intelectual compreensíveis pela comunidade intelectual mais ampla, aquela cuja fronteira é delimitada pelos códigos, e não pelo limite territorial. Conhecimento universal, próximo do que Norbert Elias atribui ao conceito de civilização, que trata do que é comum aos seres humanos, ou melhor, do que deve ser comum aos seres humanos socializados segundo regras universais de comportamento. O contraponto viria com Leite Criôlo na dimensão local deste projeto de identidade, mantendo - e é importante frisar - o compromisso com a desregionalização do discurso ${ }^{120}$. (...) O valor está na província, o progresso como ideal orienta a ação do grupo, mas a referência é local ${ }^{121}$.

Para o grupo do Clube da Esquina, as duas dimensões também estão presentes, mas numa mesma produção, na sua música, e não de forma conflituosa, mas articulada, possibilidade ocasionada pela globalização.

Segundo Canclini, tocar em temas locais e valorizá-los não só não impede a inserção no global como conduz a isso. "Narrar histórias em tempos globalizados, mesmo que seja a própria, a do lugar em que se nasceu ou se vive, é falar para outros, não apenas contar o que existe, mas também imaginá-lo fora de si ${ }^{122}$ ".

Nesse sentido, ao exibir não apenas uma "mineiridade", mas também outras regionalidades, com o uso de instrumentos andinos, ritmos africanos, muita

\footnotetext{
${ }^{119}$ Trecho da canção Os Povos, de Milton Nascimento e Márcio Borges, álbum Clube da Esquina, 1972.

${ }^{120}$ BOMENY, Helena. Guardiães da razão: modernistas mineiros. Rio de Janeiro: Editora UFRJ/ Tempo Brasileiro, 1994, p. 84.

${ }^{121}$ Idem, p. 83.

${ }^{122}$ CANCLINI, Néstor García. A Globalização Imaginada. São Paulo: Iluminuras, 2007, p. 48.
} 
percussão e elementos que lembram música de procissão, de igreja ou de festas folclóricas, o Clube da Esquina está comunicando referências regionais, específicas, que podem ter justamente a consequência apontada por Canclini de transportar o ouvinte para uma situação fora daquela vivida por ele. Nesse ponto, vale ressaltar a frase emblemática de Liev Tolstói, para quem "Se queres ser universal, começa por pintar a tua aldeia”.

Vejamos o depoimento de Flávio Venturini, um dos músicos do grupo.

Eu acho que o Clube da Esquina misturou aquele caldeirão de coisas que estavam acontecendo no mundo nos anos 70 de uma maneira muito bonita e ao mesmo tempo muito mineira, todo mundo reconhece. As pessoas falam: "Mas a música de vocês é diferente". Tem uma coisa das montanhas mesmo, que corre por aqui. Eu vejo isso até hoje nos compositores novos que aparecem, em Minas sempre teve essa vertente forte de rock, muitas bandas de rock importantes, Skank, mesmo o Sepultura, que dentro do estilo deles conquistou o mundo, sempre houve muitas bandas de rock. Mesmo na época do Clube da Esquina, eu me lembro que tinha bandas de rock como Haystack Needle, que era uma banda que o Melão fazia, tinha umas bandas de rock importantes, Tarcos, tinha essa vertente de rock pesado, Minas sempre teve isso também, mas eu acho muito mais importante essa coisa de que o Clube da Esquina abriu as portas para o mundo ${ }^{123}$.

O depoimento do músico é reforçado pelo de Márcio Borges, que aponta como o Clube da Esquina se tornou uma referência musical muito importante internacionalmente. "Esse trabalho veio realmente a ser conhecido, considerado e amado no mundo inteiro, inclusive pelas paixões das nossas vidas, como os músicos de jazz americanos, todos eles, que, de repente, estavam aparecendo nos nossos discos ${ }^{124}$,

Pensando na declaração de Canclini sobre a cidade ser o lugar onde se imagina o global, pode ser útil entender um pouco da história de Belo Horizonte. No artigo Modernização e diferenciação econômica em Belo Horizonte, de Hugo Cerqueira

\footnotetext{
${ }^{123}$ Flávio Venturini em depoimento ao Museu Clube da Esquina: www.museudapessoa.net/clube/.

${ }^{124}$ Márcio Borges em depoimento ao Museu Clube da Esquina: www.museudapessoa.net/clube/.
} 
e Rodrigo Simões, vemos como tal cidade se caracterizou desde cedo por aquilo que os autores chamam de uma "duplicidade básica em seu espaço ${ }^{125, "}$

(...) a convivência da transgressão, da mudança com a permanência, a tradição. De um lado a emergência do novo, da República, não leva à adaptação do velho, do espaço vivido na monarquia. Repensa-se tudo, escolhe-se o sítio, põe-se no chão o antigo Arraial e parte-se para a modernidade; mas não sem antes reafirmar-se o sentimento sebastianista da volta, a centralidade das Minas rediviva tentando superar a fragmentação das Geraes. De outro, a modernidade intentada, manifesta na nova urbe, aparece como síntese de um grande projeto, este permanente, vindo desde o período provincial: a construção da própria "mineiridade" 126.

A ideia é reforçada por Celina Borges Lemos ao falar da construção da cidade e também por Helena Bomeny, que trata da geração dos modernistas mineiros:

De acordo com os princípios norteadores/progressistas que nortearam a concepção da cidade, a construção de Belo Horizonte não passa de uma "entrega a domicílio" de encomenda feita pelo dirigentes políticos da época. Essa encomenda foi elaborada por "especialistas do espaço", cuja missão era construir um repertório de "símbolos monumentais" que possibilitasse a implantação de um novo status ${ }^{127}$.

A cidade, no entanto, ainda que nascida da ambição da amplitude, acaba se tornando limitada para aqueles cuja expectativa intelectual está referida ao universo cosmopolita e liberador. Liberador no sentido em que propicia a autonomia da experiência privada, estabelecendo as condições indispensáveis ao desenvolvimento do individuo, na moderna concepção do termo. A tensão entre anseio cosmopolita e experiência provinciana é o tom da analise ali desenvolvida. E é a marca do que estou chamando de duplo confronto ${ }^{128}$.

É nessa tensão entre o tradicional e o moderno que temos algumas pistas de como a música do Clube da Esquina trata de assuntos universais de maneira que é considerada tão "mineira”. Esse local que se articula com o global não está

${ }^{125}$ CERQUEIRA, Hugo E. A. da Gama e SIMÕES, Rodrigo. Modernização e diferenciação econômica em Belo Horizonte. In: Varia História. Belo Horizonte, n.18, novembro de 1997, p. 443.

${ }^{126}$ Idem.

${ }^{127}$ LEMOS, Celina Borges. Determinação do espaço urbano: a evolução econômica, urbanística e simbólica do centro de Belo Horizonte. Dissertação de Mestrado. FAFICH - UFMG, 1988, p. 70.

${ }^{128}$ BOMENY, Helena. Guardiães da razão: modernistas mineiros. Rio de Janeiro: Editora UFRJ/ Tempo Brasileiro, 1994. p.25. 
tratando de "velhas identidades", mas de identificações que atuam no interior da lógica da globalização ${ }^{129}$. Não é uma atitude de resistência ou saudosismo, mas um uso do que é de comum entendimento em uma localidade específica, que causa identificação entre seus produtores e, portanto, pode vir a causar o mesmo entre os ouvintes, para tornar possível a comunicação de algo que é mais abrangente, universal.

O conceito de cosmopolítica de Gustavo Lins Ribeiro ${ }^{130}$ pode ser interessante para entendermos essas especificidades locais, que nos termos do autor seriam "particularismos", de que trata o Clube da Esquina. Ele diferencia particularismos locais de translocais e cosmopolitas. Os primeiros seriam o conjunto de práticas e discursos mantidos em uma localidade de maneira que pareçam ser social e espacialmente delimitados e podem ser universalizados através de efeitos de poder. Os translocais são produtos de inúmeras trocas e empréstimos, ou seja, se referem a pessoas e culturas localizadas em múltiplas situações geográficas. Eles têm como ideologia central a interculturalidade, que enfatiza a mutualidade, aponta para os diferentes como relações de negociação, conflitos e empréstimos recíprocos.

Já as cosmopolíticas ou particularismos cosmopolitas são formados por discursos que tratam dos assuntos globais de forma intrínseca visando a incorporação por outros povos. Eles são conscientes de sua natureza política. Por isso, podemos pensar muitas das questões tratadas pelo Clube da Esquina como cosmopolíticas.

Sobre a consciência da natureza política, o depoimento de Márcio Borges, um dos compositores do grupo, pode ser revelador. Essa consciência, que se apresenta em diferentes níveis nas falas dos integrantes do grupo, vai ser fundamental para a discussão sobre os temas políticos no Clube da Esquina no capítulo seguinte.

[Milton] Criava estimulado pelas discussões sobre cultura, revolução, socialismo, temas obrigatórios dos papos daquela época; estimulado pelo clima geral que prenunciava grandes acontecimentos, os movimentos clandestinos crescendo, o

\footnotetext{
${ }^{129}$ HALL, Stuart. A identidade cultural na pós-modernidade. Rio de Janeiro: DP\&A, 2002, p. 78.

${ }^{130}$ RIBEIRO, Gustavo Lins. Diversidade Cultural enquanto Discurso Global. In: Revista Desigualdade e Diversidade, Revista do departamento de Sociologia e Política da PUC-Rio. Rio de Janeiro, 2008.
} 
movimento estudantil se organizando, a juventude tomando prontamente para si a responsabilidade de acelerar as transformações do planeta. Era um esquema ingênuo, muitas vezes suicida, mas havia jovens dispostos a pagar com a vida para colocá-lo em prática. Belo Horizonte, mais do que nunca, fazia parte integrante do mundo. Surgia pela primeira vez na província a consciência de pertencermos a uma civilização planetária. Parecia, por exemplo, que a nouvelle-vague era um fenômeno que acontecia ali todos os sábados, no auditório do CEC, e os estudantes de Nanterre, França, eram os mesmíssimos da Faculdade de Filosofia ali no bairro Santo Antônio, ou os de Berkeley, EUA ${ }^{131}$. (grifos meus)

Essa fala mostra como havia um sentimento de estar tratando de algo universal por parte de alguns desses músicos. Junto com os exemplos já citados daquilo que é entendido como mineiro nessas canções, outros temas presentes são referências muito abrangentes. As guitarras e as melodias com clara influência dos Beatles são aspectos que fazem parte do mundo pop. São influências vindas sobretudo de Lô Borges e Beto Guedes, os mais novos do grupo, que tinham então entre 16 e 17 anos e eram apaixonados por rock.

Segundo o próprio Lô, sua principal contribuição para a música do Clube da Esquina foi "colocar palheta no violão, fazer o instrumental com violão de aço e usar as distorção que eu e Beto gostávamos ${ }^{132}$ ". Acredito que essa é uma das principais características que diferenciam a música dos discos solo de Milton lançados até então da música do Clube da Esquina. Para Lennon e McCartney, por exemplo, gravada no disco Milton, de 1970, pode ser considerada uma prévia do que viria a ser a música do grupo, por ser uma canção de Lô e Márcio Borges e Fernando Brant, que já antecipa essa estética que mistura a harmonia mineira e os temas locais com a clara influência da música dos Beatles, presente não apenas no título, mas também no arranjo.

Algumas letras mostram também a visão dos autores do modo como sua região se articula com o mundo, além de uma crítica à posição de esquecimento e marginalização da América Latina em relação à ideia de Europa e Estados Unidos

\footnotetext{
${ }^{131}$ BORGES, Márcio. Os sonhos não envelhecem: Histórias do Clube da Esquina. São Paulo: Geração Editorial, 2009, p. 111.

${ }^{132}$ Lô Borges em entrevista concedida a esta pesquisa.
} 
como "globo"133. O engajamento pela união do continente latino-americano também é uma questão muito forte na música produzida pelo grupo e traz uma posição deste em relação à política internacional. Além de citações a esse tema, nos dois discos do grupo há gravações na língua espanhola e grande influência de ritmos latinos nas melodias analisadas.

Realizavam la labor/ De desunir nossas mãos/ E fazer com que os irmãos/ Se mirassem con temor/ Cuando passaram los años/ Se acumularam rancores/ Se olvidaram os amores/ Pareciamos extraños/ Que distância tão sofrida/ Que mundo tão separado/ Jamás se hubiera encontrado/ Sin aportar nuevas vidas ${ }^{134}$

As horas nãos e contavam/ e o que era negro anoiteceu/ enquanto se esperava/ eu estava em San Vicente/ enquanto adormecia/ eu estava em San Vicente/ coração americano/ um sabor de vidro e corte ${ }^{135}$

Se ha formado casamiento/ Todo cubierto de negros/ Negros novios y padriños/ Negros cuñados y suegros/ Y el cura que los casó/ Era de los mismos negros ${ }^{136}$

Estan clavadas dos cruces/ em el monte del olvido/ por dos amores que han muerto/ sin haberse comprendido ${ }^{137}$

Já em Lilia $^{138}$, de Milton Nascimento, por exemplo, a percussão e o cantarolar remetem aos ritmos latino-americanos desenvolvidos a partir da música espanhola.

Essa questão é discutida por Canclini, que trata da tensão entre a globalização e a defesa da identidade por parte de blocos regionais, dando o exemplo da União Europeia.

\footnotetext{
${ }^{133}$ É importante dizer que ao falar em "global" ou "universal", busco lembrar que essas categorias não são realmente tão abrangentes quanto parecem. Elas são usadas aqui para tratar de algo que é maior do que o "nacional", o que facilita minhas colocações, e não representando "todo o mundo" realmente.

${ }^{134}$ Trecho da canção Cancion por La Unidad de Latino America, de Chico Buarque de Hollanda e Pablo Milanes, álbum Clube da Esquina 2, 1978.

${ }^{135}$ Trecho da canção San Vicente, de Milton Nascimento e Fernando Brant, álbum Clube da Esquina, 1972.

${ }^{136}$ Trecho da canção Casamiento de Negros, de Violeta Parra e Polo Cabrera, álbum Clube da Esquina 2, 1978.

${ }^{137}$ Trecho da canção Dos Cruces, de Carmelo Larrea, álbum Clube da Esquina, 1972.

${ }^{138}$ Álbum Clube da Esquina, 1972.
} 
Estudos antropológicos e sociopolíticos sobre a integração européia têm mostrado que os programas destinados a construir projetos comuns não bastam para reduzir a brecha entre a Europa dos mercados ou dos governantes e a dos cidadãos. Por mais que nesse continente, mais do que em outros blocos regionais, se venha reconhecendo o papel da cultura e da dimensão imaginária nas integrações supranacionais, $a$ construção de elementos de identificação compartilhada não basta para que a maioria interiorize essa nova escala do social. Uma explicação possível para o fenômeno é que nenhum programa voluntarista de integração pode conseguir grande coisa quando não se sabe o que fazer com a heterogeneidade, isto é, com as diferenças e os conflitos que não são redutíveis a uma identidade homogênea ${ }^{139}$. (grifos meus).

A partir daí é importante pensar na tentativa da música do Clube da Esquina de integrar o bloco latino, não como um "programa voluntarista", como fala o autor, mas usando referências culturais comuns aos países latinos e o que é mais interessante, afirmando sua heterogeneidade. Esses músicos atuam como mediadores que colhem temas diversos e de distintas regiões e com eles criam sua música, característica apontada por Canclini como uma dificuldade existente na criação de uma identidade.

Segundo Homi Bhabha, "as contra-narrativas da nação que continuamente evocam e rasuram suas fronteiras totalizadoras perturbam aquelas manobras ideológicas através das quais 'comunidades imaginadas' recebem identidades essencialistas" 140 .

Com referências que juntas formam uma narrativa híbrida, a música analisada realiza a perturbação de que fala Bhabha, mostra a possibilidade de criação da identidade de uma produção musical através da diversidade. Reforça uma identidade regional tanto em nível local, no que diz respeito à mineiridade, quanto em nível continental, em relação à América Latina, e dilui a ideia de nação, de Brasil. O Clube da Esquina constrói ideias de comunidade sem essencializar. Sua essência é a diversidade.

Essa construção se liga a uma ideia elaborada por Canclini sobre a dificuldade de achar um "termo unificador" para falar dos latino-americanos.

\footnotetext{
${ }^{139}$ CANCLINI, Néstor García. A Globalização Imaginada. São Paulo: Iluminuras, 2007, p. 23.

${ }^{140}$ BHABHA, Homi K. O local da cultura. Belo Horizonte: Ed. UFMG, 1998, p.210.
} 
A cor da pele, a linguagem, o território, a religião, nada disso serve para se identificarem em conjunto. "Somos o milho, o trigo, o cânhamo" - disse-se poeticamente. Ou se tentaram listras de traços distintivos: "a vida comunitária, o amor à terra", "as celebrações ligadas aos calendários agrícolas". Quando se buscou formular uma "matriz civilizatória" que abarque todo o continente, vários argumentaram a necessidade de lhe dar uma amplitude capaz de incluir índios e mestiços. Alguns preferiram definir a condição comum a partir da perspectiva gerada pela descolonização e pelos processos atuais de luta social e cultural ${ }^{141}$. (...) Esta complexidade da definição do latino-americano a partir das "culturas originárias" tornou-se mais árdua quando reconhecemos outras vertentes multiculturais. Por exemplo, quando consideramos que a América Latina tem, junto com os 40 milhões de indígenas, uma população afro-americana de vários milhões, difíceis de precisar, como outra consequência da desatenção que sofrem nos planos de desenvolvimento ${ }^{142}$.

Entendo, a partir do que diz o autor, que a escolha do Clube da Esquina foi tratar dessas diversas referências mostrando suas diferenças e semelhanças, na busca de definir uma identidade latino-americana em que as "vertentes multiculturais" convivem. Em outro trabalho de Canclini é possível encontrar mais fontes para pensar o assunto.

O futuro dos antropólogos (e de outros cientistas sociais) depende de reassumirmos essa outra parte da disciplina que nos treinou a examinar a alteridade e a interculturalidade, as tensões entre o local e o global. James Clifford escreve que o objeto de pesquisa deve ser as "culturas translocais", as mediações entre os espaços onde se habita e os itinerários: é preciso "repensar as culturas como locais de residência e de viagem ${ }^{143 "}$.

Pensando na proposta James Clifford comentada por Canclini, observo que na produção musical analisada essa ideia corrobora a importância dada à questão do transitório, da cultura como local de itinerários e viagens, como coloca o autor. E é revelador notar como o tema da viagem, do trânsito, está presente nas letras do Clube da Esquina e tem o valor de inspiração e busca por conhecimento de coisas novas e diferentes.

\footnotetext{
${ }^{141}$ GARCÍA CANCLINI, Néstor. Diferentes, desiguais e desconectados: mapas da interculturalidade. Rio de Janeiro: Editora UFRJ, 2009, p. 57.

${ }^{142}$ Idem, p. 169.

${ }^{143}$ CANCLINI, Néstor García. A globalização imaginada. São Paulo: Iluminuras, 2007, p. 56.
} 
Para quem quer me seguir/ Eu quero mais/ Tenho o caminho do que sempre quis/ E um saveiro pronto pra partir/ Invento o cais/ E sei a vez de me lançar ${ }^{144}$

Ah! Sol e chuva na sua estrada/ mas não importa, não faz mal/ você ainda pensa e é melhor do que nada/ tudo que você consegue ser, ou nada ${ }^{145}$

Alguém que vi de passagem/ Numa cidade estrangeira/ Lembrou os sonhos que eu tinha/ E esqueci sobre a mesa/ Como uma pera se esquece/ Dormindo numa fruteira ${ }^{146}$

Caminho por uma rua/ Que passa por outros países/ Se não me vêem, eu vejo/ E saúdo velhos amigos (...) Minha vida, nossas vidas/ Formam um só diamante/ Aprendi novas palavras/ E tornei outras mais belas ${ }^{147}$

Então aqui são os integrantes do grupo que estão realizando a mediação de que fala Canclini, usam a "viagem" como lugar onde as diversas referências se encontram e são encontradas por esses músicos/viajantes, como o local da convivência entre os vários temas que vão ser incorporados à música do Clube da Esquina.

Com sua música com características regionais marcadas e referências musicais globais, o Clube da Esquina liga Minas Gerais ao mundo passando pela América Latina e mostra o diálogo entre o regional e o universal. Coloca em evidência as esquinas de Belo Horizonte influenciadas pelo pop, rock e jazz vindos de outros continentes, é cosmopolita. Nesse sentido, acredito ser possível dizer que o Clube da Esquina se insere na tradição moderna que, segundo Paz, "apaga as oposições entre o antigo e o contemporâneo e entre o distante e o próximo ${ }^{148 \text { ", }}$

Ao mesmo tempo, tem características pós-modernas, dentre elas a dissolução da importância da nação em relação ao local e ao global, como vimos. É moderno

${ }^{144}$ Trecho da canção Cais, de Milton Nascimento e Ronaldo Bastos, álbum Clube da Esquina, 1972.

${ }^{145}$ Trecho da canção Tudo que você podia ser, de Lô Borges e Márcio Borges, álbum Clube da Esquina, 1972.

${ }^{146}$ Trecho da canção Um Gosto de Sol, de Milton Nascimento e Ronaldo Bastos, álbum Clube da Esquina, 1972.

${ }^{147}$ Trecho da canção Canção Amiga, música de Milton Nascimento sobre poema de Carlos Drummond de Andrade, álbum Clube da Esquina 2, 1978.

${ }^{148}$ PAZ, Octavio. Os Filhos do Barro: do romantismo à vanguarda. Rio de Janeiro: Nova Fronteira, 1984, p. 21. 
quando valoriza o futuro, em trechos como "sei que nada será como antes amanhã $^{149 ",}$ e pós-moderno quando coloca no tempo presente o momento de mudança, ou seja, é produto de um momento de transição entre esses períodos. A identidade nacional está presente, mas a nação e suas questões não aparecem como tema ou referência fundamental, tem menos força do que as culturas locais e o global, que dialogam e tornam possível uma identificação cultural entre esses níveis, a compreensão do que é global pelos locais e do que é local pelos globais. Se o Clube da Esquina "abre as portas" deixando Minas ver o mundo, também mostra ao mundo o que é Minas.

\footnotetext{
${ }^{149}$ Trecho da canção Nada Será como Antes, de Milton Nascimento e Ronaldo Bastos, álbum Clube da Esquina, 1972.
} 


\section{2. "O que vocês fariam pra sair dessa maré?": O Clube da Esquina e seu tempo}

O que vocês diriam dessa coisa que não dá mais pé?/ O que vocês fariam pra sair dessa maré? ${ }^{150}$.

Essa pergunta estava no centro das ações e discussões no Brasil dos anos 1960 e 1970, sob o poder da ditadura militar. Ela foi respondida de várias maneiras por estudantes, intelectuais, políticos e artistas, em protestos, lutas armadas, textos, livros, filmes, músicas e tantas outras formas de manifestação. Tomando a música do Clube da Esquina como um fenômeno cultural, isto é, uma produção musical que é parte da cultura, nesse capítulo tento entender como o grupo respondeu a sua própria pergunta, ou seja, como sua música trata do debate ideológico que marcava o país naquele momento, o que dizer e o que fazer "pra sair dessa maré?". A partir de como o grupo lida com esse e outros temas que fazem parte do cenário dos anos 1970, entrarei na discussão sobre o Clube da Esquina ser ou não um movimento.

Segundo Márcio Borges, a vida no Centro de Belo Horizonte tornava obrigatória a tomada de posição politica. Em depoimento, ele conta que o bairro de Santa Tereza, onde morava com a família anteriormente, "era uma cidade do interior, um bairro afastado de onde rolava o buchicho, o movimento cultural". A mudança para o Centro da cidade no início da juventude foi um "choque cultural”, já que encontrou ali o "núcleo do movimento estudantil de Minas Gerais ${ }^{151}$ ", com o qual se identificou.

\footnotetext{
${ }^{150}$ Trecho da canção Saídas e Bandeiras $\mathbf{N}^{\mathbf{0}} \mathbf{1}$, de Milton Nascimento e Fernando Brant, álbum Clube da Esquina, 1972.

${ }^{151}$ Márcio Borges em entrevista para a pesquisa.
} 
Eu era o que na época podia se chamar de jovem alienado. Tinha vaga idéia da radicalização político-ideológica em curso; para mim, cabo Anselmo, por exemplo, era apenas um nome que me inspirava vagamente umas cenas de $O$ Encouraçado Potenkim, que vira recentemente num cineclube, levado por Sérvulo. Jango Goulart, só um presidente simpático que me fazia lembrar um jingle ainda mais simpático: ... é Jango é Jango é o Jango Goulart... Pouco me importava se o presidente queria ou não ser o nosso Willy Brandt. Eu nada sabia a respeito de "esforços de desestabilização", IBAD, Lincoln Gordon, organizações paramilitares. A verdade é que naqueles dias ainda vivia minha idade da inocência e só fui perdê-la ali, no Edifício Levy, onde vi acontecer o golpe de 31 de março de $1964^{152}$

Destaco também na fala de Márcio a ligação com a arte, principalmente com a música e o cinema. Se como vemos, sua percepção inicial sobre os fatos políticos era indissociável da memória de filmes e canções, mesmo que jingles eleitorais, ao sair do que ele chama de alienação, seu diálogo com essa realidade também vai ser por intermédio dessas duas formas de $\operatorname{arte}^{153}$. Em entrevista, o compositor revelou que na época achava a arte uma forma "menos importante e mais covarde de resistência" do que a luta armada, da qual não tinha coragem de participar, embora fosse às reuniões do movimento estudantil, assim como Milton. "Eu me achava mesmo covarde, mas hoje reconheço que minha obra também é importante porque está aí falando do que aconteceu até hoje ${ }^{154 \text { ", }}$

Se os primeiros anos da ditadura militar, de 1964 até 1968, foram de consolidação do regime, de 1968 até 1974 os brasileiros viveram os anos mais sombrios da história do país. Segundo José Murilo de Carvalho, essa segunda fase "combinou a repressão política mais violenta já vista no país com índices também jamais vistos de crescimento. Em contraste com as taxas de crescimento, o salário mínimo começou a decrescer ${ }^{155}$ ".

A censura à imprensa eliminou a liberdade de opinião; não havia liberdade de reunião; os partidos eram regulados e

\footnotetext{
${ }^{152}$ BORGES, Márcio. Os sonhos não envelhecem: Histórias do Clube da Esquina. São Paulo: Geração Editorial, 2009, p. 24.

${ }^{153}$ Além de ser letrista de muitas das músicas do Clube da Esquina, que é o objeto que nos interessa aqui, Márcio Borges também realizou projetos cinematográficos.

${ }^{154}$ Márcio Borges em entrevista para a pesquisa.

${ }^{155}$ CARVALHO, José Murilo. Cidadania no Brasil: o longo caminho. Rio de Janeiro: Civilização Brasileira, 2006, p.157.
} 
controlados pelo governo; os sindicatos estavam sob constante ameaça de intervenção; era proibido fazer greves; o direito de defesa era cerceado pelas prisões arbitrárias; a justiça militar julgava crimes civis; a inviolabilidade do lar e da correspondência não existia; a integridade física era violada pela tortura nos cárceres do governo; o próprio direito à vida era desrespeitado. As famílias de muitas das vítimas até hoje não tiveram esclarecidas as circunstâncias das mortes e os locais do sepultamento ${ }^{156}$.

Muitos dos depoimentos dos integrantes do grupo reforçam como o golpe militar foi fundamental para que tomassem algum posicionamento político. Para Joyce, cantora e compositora que participou do Clube da Esquina 2, "aconteceu tudo mais ou menos ao mesmo tempo numa época em que o Brasil estava vivendo uma ditadura militar, um momento muito forte, em que todo mundo ficou muito mexido 157 ". Um dos bateristas do grupo, Robertinho Silva, diz que era "alienado". Para ele, a consciência política surgiu através dos festivais de música popular dos anos 60. "Eu sempre vi o Brasil atrasado em certas coisas, mas foi o Geraldo Vandré que me ligou pra isso ${ }^{158}$,

Segundo Bruno Viveiros Martins, "os compositores (...) não deixaram de acompanhar, atentos, os sobressaltos que mergulharam o país democrático dos primeiros anos da década de 1960 em um estado de exceção governado pela ditadura militar ${ }^{159,}$.

Mais do que acompanhar, é possível dizer que na década seguinte, quando se deu formalmente a reunião do grupo e a produção de canções se tornou mais intensa, estas se tornaram uma forma de registrar as opiniões, sentimentos e esperanças daqueles jovens em relação ao que acontecia no país.

Que notícias me dão dos amigos?/ Que notícias me dão de você?/ Sei que nada será como está/ Amanhã ou depois de $\operatorname{amanhã~}^{160}$.

\footnotetext{
${ }^{156}$ Idem, p. 163.

157 Joyce em depoimento ao Museu Clube da Esquina. Disponível em: http://www.museudapessoa.net/clube/.

${ }^{158}$ Robertinho Silva em entrevista para a pesquisa.

${ }^{159}$ MARTINS, Bruno Viveiros. Som Imaginário: a reinvenção das cidades nas canções do Clube da Esquina. Belo Horizonte: Editora UFMG, 2009, p.26.

${ }^{160}$ Trecho da canção Nada será como antes, de Milton Nascimento e Ronaldo Bastos, álbum Clube da Esquina, 1972.
} 
$\mathrm{O}$ que foi feito amigo/ De tudo o que a gente sonhou/ O que foi feito da vida/ $\mathrm{O}$ que foi feito do amor ${ }^{161}$

Um espelho feria meu olho e na beira da tarde/ uma moça me vê/ queria falar de uma terra com praias no norte/ e vinhos no $\mathrm{sul} / \mathrm{a}$ praia era suja e o vinho vermelho, vermelho secou ${ }^{162}$

A última canção citada, Ao que vai nascer, chegou a ter trechos censurados.

Segundo Fernando Brant, a nova letra, feita para substituir a censurada, era mais crítica e ainda assim foi aprovada:

Foi censurado, porque falava assim: "Brasil é o país do futuro/Meus filhos, meus netos, o futuro está aqui." Tinha outros pedaços. Falavam que não podia, que era censurado porque "Brasil é o país do futuro" era o slogan da campanha do governo Médici, de um deles. Tinha o "Ame-o ou deixe-o" e tinha "O Brasil é o país do futuro". "Bom, tudo bem, vou mudar". Eu mudei, falando a mesma coisa, eu acho que piorando, e passou. Eu falei assim: "Queria falar de uma terra com praias no norte e vinhos no sul/A praia era suja, e o vinho vermelho, vermelho, secou/Acabou a festa, guardo voz e o violão/Ou sai por aí, raspando as cores para o mofo aparecer". Era exatamente o milagre brasileiro. Eles estavam colorindo tudo, mas você tinha que raspar, que de baixo era mofo. E isso $\operatorname{passou}^{163}$.

Espécie de líder do grupo, Milton Nascimento via na música, segundo sua biógrafa, Maria Dolores Pires do Rio Duarte, uma forma de resistência.

Milton Nascimento não era visto com bons olhos pelos militares. Embora não fosse do tipo de subir no palanque e discursar contra a ordem vigente, suas músicas apresentavam um forte conteúdo político e ideológico, amenizado, de forma sutil, pela bandeira da amizade. (...) Apesar das dificuldades, não passava pela cabeça de Bituca deixar o Brasil. Auto-exílio era algo que, com certeza, não combinava com ele. "Podem até me matar, mas não saio daqui", dizia ${ }^{164}$.

\footnotetext{
${ }^{161}$ Trecho da canção O Que Foi Feito Devera, de Milton Nascimento e Fernando Brant, álbum Clube da Esquina 2, 1978.

162 Trecho da canção Ao que vai Nascer, de Milton Nascimento e Fernando Brant, álbum Clube da Esquina, 1972.

${ }^{163}$ Fernando Brant em depoimento ao Museu do Clube da Esquina.

${ }^{164}$ DUARTE, Maria Dolores Pires do Rio. Travessia: a vida de Milton Nascimento. Rio de Janeiro: Record, 2006, p. 149.
} 
Em depoimento ao Museu do Clube da Esquina, Milton faz afirmações que mostram como a existência da repressão e da censura significava simultaneamente medo e inspiração para sua música.

Então, teve um negócio aqui que aconteceu, que a crítica era muito má, maliciosa comigo, né. Ajuntou muita coisa pra cima de mim, que os olhos estavam voltados pra mim. Enquanto isso, fomos trabalhando com os estudantes. Agora, ao mesmo tempo que era uma coisa assim, de amor ao meu país, e me solidarizar com os estudantes, eu tive muito problema, você sabe. Problema de censura nos discos, como o Milagre dos Peixes, que foi quase todo censurado. A Odeon queria que eu fizesse outro disco, eu falei: "não, vai sair desse jeito", usando a voz como instrumento, como uma arma. E olhe que tentaram censurar a voz também ${ }^{165}$.

Essas informações corroboram com a ideia de que Milton era um artista que se posicionava politicamente através de sua música e que isso tinha que ser feito muitas vezes de forma sutil, indireta, uma forma de tratar do cenário político que está muito presente na música do Clube da Esquina.

Nesse ponto, retomo a ideia de "politização do cotidiano" de Messeder Pereira ${ }^{166}$, com a qual operei na introdução deste trabalho. $\mathrm{O}$ autor traz esse conceito para explicar que as grandes questões dos anos 70 são trabalhadas como interferências no cotidiano das pessoas, diferente da década de 60, em que exigiam uma imensa movimentação.

Ao falar da poesia marginal também nos anos 70, o autor afirma que a crítica social não foi estancada pela repressão sistemática como os defensores da ideia de um "vazio cultural” nessa época afirmam, mas, ao contrário, ela não só persistia como descobria novas áreas de atuação.

Certas questões e certos problemas que faziam parte do 'senso comum intelectual' dos anos 60 (estando presentes em toda e qualquer discussão) não tinham mais, nos 70, o mesmo peso e a mesma presença no debate cultural. Dentre os inúmeros elementos que poderiam ser referidos por terem sofrido esta mudança de ênfase, (...) refiro-me aqui à questão da criação de uma 'cultura popular' ou, mais especificamente, de uma

\footnotetext{
165 Milton Nascimento em depoimento ao Museu Clube da Esquina: www.museudapessoa.net/clube/.

${ }^{166}$ PEREIRA, Carlos Alberto Messeder. Retrato de época: poesia marginal anos 70. Rio de Janeiro, FUNARTE, 1981.
} 
'cultura popular revolucionária' - elemento chave do debate dos anos 60 - e, também, às concepções de engajamento (mais especificamente, artístico) daí derivadas ${ }^{167}$.

Em entrevista, Ronaldo Santos, poeta que participava do grupo "Nuvem Cigana" assim como Ronaldo Bastos, letrista da canção homônima, fala sobre esse sentido político do cotidiano daquela geração de artistas e sobre a forma diferente de lidar com a censura em comparação à geração anterior, dos anos 1960:

(...) a própria maneira da gente viver acabava indo contra a transação toda que estava aí. A gente gostava de trabalhar junto, de curtir junto, de produzir uma coisa mais eficaz em termos de mobilizar as pessoas. A gente tinha certeza de que era preciso estar vivo, que o bode não tava com nada. A gente não queria ficar quietinho esperando a chuva passar, a gente continuava gostando de tudo que era bom. E sabíamos que tínhamos direito. Então, não havia programa, partido, palavra de ordem. Não, a gente resistia porque era a única forma de existir ${ }^{168}$.

Falando sobre a música do Clube da Esquina e o momento em que é produzida, Márcio Borges afirma:

A grande argamassa que juntou os tijolinhos foi a ditadura. Não vejo nenhum valor positivo nisso, mas a ditadura nos incitou a ficarmos cada vez mais unidos, a sermos cada vez mais corretos nas nossas decisões, para que, cada vez mais, nós nos colocássemos como uma oposição a essa afronta aos direitos humanos, aos direitos civis. Que nós nos colocássemos cada vez mais contra a violência e, principalmente, contra a violência promovida pelo próprio Estado. Esse Estado era um Estado de falência total dos valores. Aquilo que teria que zelar pelos seus cidadãos estava conspirando contra eles ${ }^{169}$.

Entre as letras de Márcio que tratam do contexto dos anos 1970, destaco Tudo que você podia ser, em que vejo já no título uma sensibilidade contracultural, que chega a tocar no nome de Emiliano Zapata ${ }^{170}$ e fala do cerceamento de possibilidades de ser e querer, além de Clube da Esquina $n^{\circ} 2$.

\footnotetext{
${ }^{167}$ Idem, p. 349.

168 PEREIRA, Carlos Alberto Messeder e HOLLANDA, Heloísa Buarque de. Patrulhas Ideológicas - Marca Reg.: arte e engajamento em debate. São Paulo: Brasiliense, p.252.

${ }^{169}$ Márcio Borges em depoimento ao Museu Clube da Esquina: www.museudapessoa.net/clube/.

${ }^{170}$ Emiliano Zapata foi um dos líderes da Revolução Mexicana, de 1910, contra a ditadura de Porfírio Dias.
} 
Sei um segredo/ você tem medo, só pensa agora em voltar/ não fala mais na bota e no anel de Zapata/ tudo que você devia ser, sem medo ${ }^{171}$

Porque se chamavam homens/ Também se chamavam sonhos/ $\mathrm{E}$ sonhos não envelhecem/ Em meio a tantos gases lacrimogênios ficam calmos calmos calmos ${ }^{172}$

Para Fernando Brant, o contexto determinava a politização das letras que fazia, mas a escolha da música como forma de expressão aconteceu por ser amigo de Milton, e não por ter um interesse maior por essa forma de arte. "Nunca me preocupei com o público, em vender. Eu disse as coisas que queria dizer e deu certo porque era o que a minha geração também queria dizer ${ }^{173 "}$. São de Fernando as emblemáticas $O$ que foi feito devera, uma "reflexão sobre tudo que tínhamos realizado em 11 anos de estrada ${ }^{174,}$, e San Vicente, feita para uma peça sobre um golpe militar em um país fictício da América Latina, que "reflete as minhas impressões e sentimentos em relação ao momento que não só o Brasil, como a América Latina inteira, estavam vivendo: a chegada da opressão, da ditadura ${ }^{175}$ ",

Falo assim sem tristeza/ Falo por acreditar/ Que é cobrando o que fomos/ Que nós iremos crescer ${ }^{176}$

Coração americano/ Acordei de um sonho estranho/ Um gosto de vidro e corte ${ }^{177}$

Em entrevista para esta pesquisa, Ronaldo Bastos foi quem se mostrou mais interessado em retratar o Clube da Esquina como um projeto cultural e político e descreveu a si e aos amigos do grupo como possuidores de uma "marginalidade

\footnotetext{
${ }^{171}$ Trecho da canção Tudo que você podia ser, de Lô Borges e Márcio Borges, álbum Clube da Esquina, 1972.

172 Trecho da canção Clube da Esquina n $\mathbf{n}^{\mathbf{2}}$, de Milton Nascimento, Lô Borges e Márcio Borges, álbum Clube da Esquina, de 1972.

${ }^{173}$ Fernando Brant em entrevista concedida a esta pesquisa.

${ }^{174}$ BRANT, Fernando. Fernando Brant em depoimento a Liana Fortes. Rio de Janeiro: Ed. Rio, 2005. (Coleção Gente), p. 75.

${ }^{175}$ Idem, p. 51.

${ }^{176}$ Trecho da canção O que foi feito devera, de Milton Nascimento e Fernando Brant, álbum Clube da Esquina 2, 1978.

${ }^{177}$ Trecho da canção San Vicente, de Milton Nascimento e Fernando Brant, álbum Clube da Esquina, 1972.
} 
entranhada”, também comentada por Márcio como uma característica pessoal importante.

Ronaldo afirma que eles foram "criadores de uma vanguarda real, feita para chocar e mudar a vida das pessoas ${ }^{178,}$. É nas letras deste autor que a sensibilidade contracultural apontada por autores como Santuza Cambraia Naves ${ }^{179}$ e Bernardo Novais da Mata Machado ${ }^{180}$ é mais visível. Em Cais, por exemplo, o sujeito inventa seu próprio caminho e a forma de segui-lo, com uma liberdade encontrada também em Nuvem Cigana e Nada Será Como Antes.

Tenho o caminho do que sempre quis/ E um saveiro pronto pra partir/ Invento o cais/ E sei a vez de me lançar ${ }^{181}$

O meu nome é nuvem/ Ventania, flor de vento/ Eu danço com você o que você dançar/ Se você deixar o coração bater sem medo ${ }^{182}$

Num domingo qualquer, qualquer hora/ Ventania em qualquer direção/ Sei que nada será como antes, amanhã ${ }^{183}$

A existência de uma sensibilidade contracultural na música do Clube da Esquina surgiu para esta pesquisa como questão em oposição a uma ideia de que o que haveria nessa produção seria mais uma ruralidade do que contracultura. Vários pontos foram fundamentais para pensar esse assunto:

Nas entrevistas com os integrantes, tive pistas para os dois caminhos. Ao conversar com Tavinho Moura, por exemplo, a ideia de ruralidade é muito forte, vem com as influências do interior de Minas Gerais, das festas religiosas e das congadas na rua. Para me explicar as características de sua música, ele fala das "raízes da música mineira", de montanhas, de introspecção e afirma: "A música

\footnotetext{
${ }^{178}$ Ronaldo Bastos em depoimento concedido a esta pesquisa.

${ }^{179}$ NAVES, Santuza Cambraia. Canção popular no Brasil: a canção crítica. Rio de Janeiro: Civilização Brasileira, 2010.

${ }^{180}$ BUENO, Andréa dos Reis Estanislau (org.). Coração americano: 35 anos do álbum Clube da Esquina. Belo Horizonte: Prax, 2008.

${ }^{181}$ Trecho da canção Cais, de Milton Nascimento e Ronaldo Bastos, álbum Clube da Esquina, 1972.

${ }^{182}$ Trecho da canção Nuvem Cigana, de Lô Borges e Ronaldo Bastos, álbum Clube da Esquina, 1972.

${ }^{183}$ Trecho da canção Nada Será como Antes, de Milton Nascimento e Ronaldo Bastos, álbum Clube da Esquina, 1972.
} 
daqui não é uma música que veio a partir do ritmo, como o samba, por exemplo. Veio de harmonia e melodia. Desde pequeno arrumando rua pra procissão passar, congada na esquina. A nossa música é muito reflexo disso ${ }^{184}$ ". E termina com o seguinte conselho para mim, muito revelador dessa postura de tentar naturalizar o processo musical: "Não tenta entender o balaio de gato não, porque perde a $\operatorname{graça}^{185,}$.

O mesmo acontece ao entrevistar Nelson Angelo, que afirma:

Não tínhamos planejamento de nada. A temática das músicas era escolhida por uma trama entre a melodia e as regras inexoráveis que vinham dela. Tinha uma regra, mas não se falava sobre ela, é atávica. Era algo que nascia de dentro pra fora, ninguém dizia o que podia ou não fazer, mas sabia. O tema era música de qualidade ${ }^{186}$.

E Toninho Horta, em entrevista, diz: "Nunca tivemos uma postura política. Queríamos fazer músicas e letras que falassem da natureza, do amor, do cotidiano $^{187,}$.

Já Márcio Borges e Ronaldo Bastos fazem colocações totalmente conectadas com a sensibilidade contracultural, como vimos, afirmando o gosto por tudo o que era marginal, buscando fazer uma música para "chocar".

Uma entrevista que Milton Nascimento concede a Fernando Brant também pode ser importante para entender essa questão. Eles comentam como existia um sentimento de necessidade de mudança por parte de toda sua geração nas mais diversos pontos do mundo.

Fernando: Lendo o livro de George Martin sobre os Beatles, tive a nítida impressão de que ele não falava nos quatro garotos ingleses e, sim, de nós, jovens mineiros e brasileiros, criando nossos primeiros discos. Era o mesmo tipo de bagunça e energia criativa. (...) Milton: Eu acho que realmente era tudo igual. Muito me perguntam sobre a influência dos Beatles na nossa música e eu acho o seguinte: numa determinada época, surgiu uma espécie de sentimento musical em várias partes do mundo, muitos tinham mais ou menos a mesma estrela guia. Os arranjos de George Martin, a maneira dos Beatles de cantar, de fazer

\footnotetext{
184 Tavinho Moura em depoimento concedido para esta pesquisa.

${ }^{185}$ Idem.

${ }^{186}$ Nelson Angelo em depoimento concedido para esta pesquisa.

${ }^{187}$ Entrevista de Toninho Horta em E: Clube da Esquinalentrevista toninho horta.mht
} 
música, tudo isso tinha muito a ver com o que se fazia em vários outros lugares do mundo, como em Minas Gerais. Era mais uma questão de época do que de influência de um sobre o outro. Acontece que se fosse o contrário, se a gente tivesse nascido em Liverpool, diriam que a gente teria influenciado os Beatles $^{188}$.

Além de falar da busca pela mudança e da conexão entre a juventude mundial, sentimentos próprios da geração da contracultura, o trecho reforça a ideia de articulação do grupo com o global. Em Os Beatles eram Rolling Stones, Ronaldo Bastos fala do mesmo assunto e dá sua opinião sobre a relação da mídia na época com o Clube da Esquina.

Nós éramos jovens e só nos interessava a revolução. Abominávamos a ignorância da direita e a burrice de certos setores da esquerda. Queríamos mudar o mundo e estivemos perto de mudá-lo em 1968. Ou, pelo menos, acredito que o mundo nunca mudou tanto em tão pouco tempo. E a música brasileira mudou para sempre. O Clube da Esquina nunca foi perdoado por não ter feito média com a mídia. Tenho ainda uma matéria de uma importante revista da época, cujo título era "Esses são os Beatles brasileiros". Pois os Beatles eram Rolling Stones e não tinham muito tempo para ficar fazendo jogo de cena $^{189}$.

Há uma afirmação de Márcio que corrobora a sensação que tive durante as entrevistas, de que ele e Ronaldo teriam ideias diferentes dos demais participantes do grupo:

Salvo uma ou outra atitude mais avant-garde minha ou de Ronaldo, o quarteto criativo que formávamos com Bituca e Fernando permaneceu mais ou menos alheio a essas coisas, embora achando muito natural o uso de guitarras elétricas, etc $^{190}$.

Ou seja, há por parte de alguns membros do Clube da Esquina uma ligação com o "ideário anti-establishment criado pelos segmentos contraculturais dos Estados Unidos e pelos estudantes e intelectuais que participaram do Maio de 68 na

\footnotetext{
${ }^{188}$ BUENO, Andréa dos Reis Estanislau (org.). Coração americano: 35 anos do álbum Clube da Esquina. Belo Horizonte: Prax, 2008, p. 31.

${ }^{189}$ Idem, p. 53.

${ }^{190}$ BORGES, Márcio. Os sonhos não envelhecem: Histórias do Clube da Esquina. São Paulo: Geração Editorial, 2009, p. 207.
} 
França ${ }^{191}$ ", existe o incômodo tanto com a direita quanto com a esquerda politicas e a consequente vontade de realizar algo novo, revolucionário. Para Maria Isabel Mendes de Almeida e Santuza Cambraia Naves, que tratam das diferentes experiências contraculturais dos anos 60 e 70 até as mais recentes no Brasil,

esses movimentos rompem com a "esquerda" tradicional ao rejeitarem seu "modelo sindical e associativo", no qual, segundo Silvia Ramos, "a cultura do 'coletivo' deve imperar sobre trajetórias individuais. Outra ruptura com a militância em moldes centralizadores observa-se na afirmação política da negritude, a qual, em vez de se restringir ao discurso, concretiza-se fortemente no corpo, através da postura, do cabelo afro e do figurino, e na musicalidade, por meio de ritmos negros ${ }^{192}$.

Tomando estas como características de experiências contraculturais, sugiro a existência desse tipo de sensibilidade na música do Clube da Esquina. Sobre a afirmação da negritude, este é o tema do próximo capítulo, em que falo de como alguns grupos étnicos são temas recorrentes na produção analisada.

Em relação a cultura do coletivo de que falam as autoras, ela é justamente uma das características que me fizeram olhar para a forma como o Clube da Esquina faz suas escolhas musicais, já que a criação das músicas tem sempre, segundo os depoimentos e fichas técnicas, a participação de muitos integrantes, é feita no que é descrito por vários deles como um "clima de comunidade", em que "Cada um chegava e fazia o que queria, tinha uma liberdade de improvisação muito grande ${ }^{193}$ ".

Outro autor que chama a atenção para o tema é Bernardo Novais da Mata Machado, que mostra demais características da música do Clube da Esquina que podem ser relacionadas com a sensibilidade contracultural. Ele parte do filme 194 $^{19}$ que inspirou as primeiras parcerias musicais de Milton Nascimento e Márcio Borges, as canções Paz do Amor que vem (Novena), Gira-Girou e Crença.

\footnotetext{
${ }^{191}$ ALMEIDA, Maria Isabel Mendes de e NAVES, Santuza Cambraia (orgs.). "Por que não?”: rupturas e continuidades da contracultura. Rio de Janeiro: 7Letras, 2011, p. 7.

${ }^{192}$ Idem, p. 8.

${ }^{193}$ Danilo Caymmi em depoimento concedido a esta pesquisa.

${ }^{194}$ Jules et Jim é um filme de 1962 dirigido por François Truffaut.
} 
Jules et Jim é um libelo à amizade e à liberdade, uma exaltação do amor e da vida liberta das convenções sociais. Uma obra ao mesmo tempo lírica, dramática e épica, gêneros que irão compor a música e a poesia do Clube da Esquina. Um filme que prenuncia uma nova atitude diante do mundo, misto de irreverência, coragem, inocência quase infantil e entrega ao(s) outro(s); posturas próprias da geração da contracultura ${ }^{195}$.

\section{O autor então explica conceito de contracultura:}

O movimento da contracultura, que nasce com a geração beatnik, nos anos 50, nos Estados Unidos, e que eclode mundialmente nas décadas de 1960/70, com o nome de movimento hippie, coloca em xeque tudo o que na época era chamado de "sistema": o poder patriarcal dos homens sobre as mulheres, a família nuclear, a repressão sexual, o consumismo, a burocratização da vida, o trabalho alienado, a desumanização das cidades, a guerra nuclear, os preconceitos raciais e étnicos, a medicina alopática, a alimentação com base na carne animal, o cientificismo (junto com o tecnicismo e o racionalismo que o acompanham), a moral puritana e a destruição da natureza (...).

É possível ver muitos dos aspectos citados pelo autor na música do Clube da Esquina. E é importante observar que muitos dos participantes do grupo se descrevem como hippies ao falarem da época em que os discos foram produzidos, como vemos nos depoimentos de Luiz Alves, Nelson Angelo e Robertinho Silva.

E foi o José Mynsen quem impulsionou o Milton, que já estava com aquela nova concepção de hippie, do movimento de paz e amor, essas coisas todas. E o José Mynsen deu a idéia de a gente fazer uma coisa mais descontraída, com todo mundo sem camisa, com cordão ${ }^{196}$.

Aí já vem uma história que foi da fase dos anos 70, da coisa hippie, que me fascinou muito, que é a idéia da não-fronteira. Queríamos mesmo um mundo sem fronteiras, sem limites. Uma coisa de liberdade e cabeça ${ }^{197}$.

É que a gente tinha influência do movimento hippie. O que se ouvia na época: "Vamos quebrar as estruturas." Então tudo era careta. Era careta ter dinheiro no bolso, ter conta em banco, comer feijão com arroz. O negócio era pãozinho integral e

${ }^{195}$ BUENO, Andréa dos Reis Estanislau (org.). Coração americano: 35 anos do álbum Clube da Esquina. Belo Horizonte: Prax, 2008, p. 105.

${ }^{196}$ Luíz Alves, músico participante do Clube da Esquina, em depoimento ao Museu Clube da Esquina: www.museudapessoa.net/clube/.

${ }^{197}$ Nelson Angelo, músico participante do Clube da Esquina, em depoimento ao Museu Clube da Esquina: www.museudapessoa.net/clube/. 
cabelo espichado. Tomar muito banho também não era permitido $^{198}$.

Segundo Toninho Horta, "naquela época todo mundo era meio hippie, de bigodinho, bico fino, cabelão"199. Para Flávio Venturini, “a barra era muito pesada, a gente era muito parado na rua, eu com cabelos imensos e aquela cara de hippie" ${ }^{200}$.

Sobre a burocratização da vida, citada por Mata Machado como um dos aspectos criticados pela contracultura, ela está presente de forma reveladora no texto de Márcio Borges. No trecho do livro em que fala sobre a profissão de Milton Nascimento, que era escriturário antes de se tornar músico profissional, o autor comenta o conselho que deu ao amigo na época. "Você não é um burocrata que vai passar a vida atrás de uma máquina de escrever nesta cidade horrorosa, é? As pessoas se mobilizando para criar um mundo novo, derrubar as tiranias e você lá obedecendo às ordens do Capitão César ${ }^{201}$ ".

Como não pode deixar de ser neste trabalho, a análise das músicas é fundamental para discutir a contracultura dentro da produção do Clube da Esquina. Além de algumas letras já citadas como exemplo, a influência do rock, de Beatles ao progressivo, também pode ser entendida como parte do universo contracultural, além da questão do transitório, pensado em termos de viagens, como vimos no capítulo anterior.

Coração americano/ um sabor de vidro e corte/ A espera na fila imensa/ e o corpo negro se esqueceu/ estava em San Vicente/ a cidade e suas luzes/ estava em San Vicente/ as mulheres e os homens/ coração americano/ com sabor de vidro e corte c2 $^{202}$

\footnotetext{
${ }^{198}$ Robertinho Silva, músico participante do Clube da Esquina, em depoimento ao Museu Clube da Esquina: www.museudapessoa.net/clube/.

${ }^{199}$ Toninho Horta, músico e arranjador participante do Clube da Esquina, em depoimento ao Museu Clube da Esquina: www.museudapessoa.net/clube/.

${ }^{200}$ Flávio Venturini, compositor e músico participante do Clube da Esquina, em depoimento ao Museu Clube da Esquina: www.museudapessoa.net/clube/.

${ }^{201}$ BORGES, Márcio. Os sonhos não envelhecem: Histórias do Clube da Esquina. São Paulo: Geração Editorial, 2009, p. 46.

${ }^{202}$ Trecho da canção San Vicente, de Milton Nascimento e Fernando Brant, álbum Clube da Esquina, 1972.
} 
Corre a bola/ rola o circo/ Alegria tudo, tudo é carnaval/ No silêncio dessas matas muitas coisa viva/ tem pra se matar/ Picadeiro sem palhaço/ Todos os aplausos são para o leão ${ }^{203}$

Ao analisar o desenvolvimento da salsa como manifestação de uma identidade caribenha no contexto hegemônico da globalização, Angel G. Quintero Rivera trata da importância da incorporação de referências do rock nessa produção como forma de expressão e resistência cultural dos jovens.

Ahora bien, la innovación en la sonoridad "tropical" a través de la incorporación de elementos del rock (o el jazz/rock fusion) constituye un fenómeno de especial importancia para el análisis cultural del mundo contemporáneo, sobre el cual debemos detenernos. Antes adelanté que la salsa había surgido en gran medida como respuesta de la cultura juvenil latinocaribeña al intento homogenizador que la difusión del rock por el mundo, o su "globalización", parecía implicar, y al presentismo hedonista de su noción del tiempo. Para los jóvenes de una cultura ${ }^{-}$como la caribeña ${ }^{-}$atravesada por la incertidumbre, (...), para esos jóvenes cuyas identidades ${ }^{-}$en sus múltiples dimensiones ${ }^{-}$se encontraban constantemente necesitadas de reconstituirse, la rebeldía generacional ante el futuro ("el progresso") ofrecido o empujado por el establishment adulto, tenía poco sentido, cuando tanto para ellos, como para sus mayores, incluso sus posibilidades mismas de futuro se encontraban cuestionadas.(...) La música "tropical" no tenía que presentarse ya de manera dicotómica ante el rock, sino reafirmar su triunfo frente al mimetismo homogeneizante. Salsero y rockera podían alternar festivamente, a la vez que se presentaba, como invitado especial, al pionero ${ }^{-}$Rohena, evidente representante de la compleja hibridez popular ${ }^{-}$que había comenzado a incorporar en los inicios mismos de la conformación de esta nueva manera de hacer música elementos de rock a su libre combinación salsera $^{204}$.

Assim como na cena descrita pelo autor, na música do Clube da Esquina a incorporação de referências do rock está ligada à ideia de juventude e resistência cultural. Combinadas às referências regionais, elas ao mesmo tempo fazem uma ligação entre a juventude mineira e brasileira e outros grupos jovens mundo afora e transformam as canções analisadas em uma produção com características singulares.

\footnotetext{
${ }^{203}$ Trecho da canção Pão e Água, de Lô Borges, Márcio Borges e Roger Mota, álbum Clube da Esquina 2, 1978.

${ }^{204}$ RIVERA, Angel G. Quintero. Salsa, identidad y globalización. Redefiniciones caribeñas a las geografías y el tempo. TRANS - Revista Transcultural de Música, Trans 6 (2002).
} 
Por tudo o que foi considerado, acredito ser possível afirmar a existência de sensibilidade contracultural na produção do Clube da Esquina. Existe também uma ruralidade, o que não impede a existência da contracultura e vice-versa, principalmente se pensarmos que esta tem como pontos importantes a critica à destruição da natureza e à desumanização das cidades, o que acaba aparecendo igualmente como uma valorização do meio rural.

Sol, girassol, verde vento solar/ você ainda quer morar comigo/ vento solar e estrelas do mar/ um girassol da cor do seu cabelo $^{205}$

Mensageiro natural/ de coisas naturais/ quando eu falava dessas cores mórbidas/ quando eu falava desses homens sórdidos/ quando eu falava desse temporal ${ }^{206}$

Recusando a sobremesa/ um prato de ouro e um copo de vinho/ como o velho Chaplin eu jogo na cara/ tanta coisa pobre, pelo amor de Deus ${ }^{207}$

Nas canções citadas, a valorização da natureza, a liberdade sexual e amorosa e a crítica ao status quo aparecem como temas importantes relacionados também à contracultura. A menção a Charlie Chaplin também é interessante, já que o artista foi, através do cinema, um dos maiores críticos da modernidade.

Ao designar a música do Clube da Esquina como portadora de uma sensibilidade contracultural, existe uma tensão da qual não devo fugir, que é o modo como esse fenômeno musical se tornou, mais tarde, parte do establishment, como apontei em algumas passagens. Não à toa, essa institucionalização incomoda alguns integrantes do grupo.

Pensando a cena belo-horizontina do momento em que são lançados os discos analisados vejamos o que Hugo Cerqueira e Rodrigo Simões afirmam no artigo Modernização e diferenciação econômica em Belo Horizonte. Segundo os autores, a cidade consolida sua posição de polo econômico regional nos anos 60 .

\footnotetext{
${ }^{205}$ Trecho da canção Um Girassol da Cor do Seu Cabelo, de Lô Borges e Márcio Borges, álbum Clube da Esquina, 1972.

${ }^{206}$ Trecho da canção Paisagem da Janela, de Lô Borges e Fernando Brant, álbum Clube da Esquina, 1972.

${ }^{207}$ Trecho da canção Pelo Amor de Deus, de Milton Nascimento e Fernando Brant, álbum Clube da Esquina, 1972.
} 
A partir dos 70, ela reafirma essa característica levando o estado a "experimentar taxas de crescimento industrial que acompanham o "milagre econômico,208,".

O deslocamento da população do campo para a cidade também foi muito intenso nessa época. Sobre as consequências dessa migração, Octavio Ianni vai mostrar que a concentração de poder político passa cada vez mais para as mãos de quem tem o poder econômico.

(...) diversificam-se as atividades produtivas, as relações de produção e as classes sociais. Tanto cresce o predomínio da cidade e da indústria sobre o campo e a agricultura como crescem as articulações entre a cidade e o campo, a indústria e a agricultura. Cada vez mais larga e intensamente o grande capital financeiro e monopolista (combinando a indústria, o banco, o comércio e a agricultura) conquista e reconquista a sociedade e o Estado. É nesse contexto que cresce e alarga-se o poder da grande burguesia. Ao mesmo tempo em que se diversificam as relações de produção e as classes sociais, sob a ditadura militar aumenta o predomínio da grande burguesia ${ }^{209}$.

Na visão de José Murilo Carvalho ${ }^{210}$, a grande urbanização beneficiou os direitos políticos, mas levou à formação de metrópoles com grande concentração de populações marginalizadas. Esses acontecimentos influenciam a postura crítica dos músicos do Clube da Esquina em sua produção.

Nesse sentido, é significativa a presença do tema da viagem nas músicas do Clube da Esquina. Nessas viagens, em que o trem é o meio de transporte mais citado, aparece de maneira muito forte a valorização das cidades pequenas, interioranas, de uma vida considerada mais simples e tranquila. Há nessa música um olhar para o interior, justamente o contrário do trajeto que está sendo feito pela maioria da população nesse período.

\footnotetext{
${ }^{208}$ CERQUEIRA, Hugo E. A. da Gama e SIMÕES, Rodrigo. Modernização e diferenciação econômica em Belo Horizonte. In: Varia História. Belo Horizonte, n.18, novembro de 1997, p. 447.

${ }^{209}$ IANNI, Octavio. Pensamento Social no Brasil. Bauru, SP: EDUSC, 2004, p. 290.

${ }^{210}$ CARVALHO, José Murilo. Cidadania no Brasil: o longo caminho. Rio de Janeiro: Civilização Brasileira, 2006, p.194.
} 
Eu já estou com o pé nessa estrada/ Qualquer dia a gente se $v \hat{e}^{211}$

Se você quiser eu danço com você/ No pó da estrada/ Pó, poeira, ventania/ Se você soltar o pé na estrada/ Pó, poeira/ Eu danço com você o que você dançar ${ }^{212}$

Sair dessa cidade ter a vida onde ela é/ Subir novas montanhas, diamantes procurar/ no fim da estrada e da poeira/ um rio com seus frutos me alimentar ${ }^{213}$

Nada a temer, nada a combinar/ na hora de achar o meu lugar no trem/ e não sentir pavor dos ratos soltos na praça/ minha casa/ Não precisa ir muito além dessa estrada ${ }^{214}$

A viagem no sentido contrário da migração que está acontecendo no período pode indicar uma resistência à intensa urbanização e endurecimento da cidade, uma apropriação do simples, natural e livre das novas tecnologias como bom, o que, como vimos, também é valorizado no universo da contracultura.

Sobre o Centro de Belo Horizonte como local da efervescência política e cultural da cidade, é importante entender mais sobre os pontos frequentados pelos músicos do Clube da Esquina, como a Rua da Bahia.

A ligação estabelecida entre a Praça da Estação e a Praça da Liberdade foi encurtada pela Rua da Bahia. Esta, além de agilizar o percurso entre as praças, abrigava serviços de comércio e alguns serviços públicos, a exemplo dos colégios, a Escola de Direito, a Biblioteca Pública e a Câmara dos Deputados. Tais atividades só fizeram reforçar a importância dessa rua que, além de ser o 'centro de gravidade' entre a 'praça cívica' e a 'praça de chegada' da cidade, atraía progressivamente atividades de relevância funcional para a região ${ }^{215}$.

E Celina Borges Lemos completa:

\footnotetext{
${ }^{211}$ Trecho da canção Nada será como antes, de Milton Nascimento e Ronaldo Bastos, álbum Clube da Esquina, 1972.

${ }^{212}$ Trecho da canção Nuvem Cigana, de Lô Borges e Ronaldo Bastos, álbum Clube da Esquina, 1972.

${ }^{213}$ Trecho da canção Saídas e Bandeiras No1, de Milton Nascimento e Fernando Brant, álbum Clube da Esquina, 1972.

${ }^{214}$ Trecho da canção Trem de Doido, de Lô Borges e Márcio Borges, álbum Clube da Esquina, 1972.

${ }^{215}$ LEMOS, Celina Borges. Determinação do espaço urbano: a evolução econômica, urbanística e simbólica do centro de Belo Horizonte. Dissertação de Mestrado. FAFICH - UFMG, 1988, p. 79.
} 
Com a entrada do Brasil na I Guerra Mundial, outras manifestações ocorreram no Centro institucionalizando-o como local cristalizado da expressão política. O Teatro Municipal era o ponto de referência para a organização das passeatas que, geralmente, desciam de forma organizada para a Avenida Afonso Penna, esquina com Rua da Bahia ${ }^{216}$.

No guia publicado sobre a cidade, o Museu do Clube da Esquina apresenta a Rua da Bahia como "palco privilegiado da revolução dos costumes a partir dos anos $1960^{217}$ ". Na Avenida Augusto de Lima, quase esquina com a Rua da Bahia, fica o edifício Archângelo Maletta, também muito frequentado pelo grupo. Inaugurado no início dos anos 1960, tornou-se ponto de encontro entre intelectuais, jornalistas, políticos e estudantes, que se reuniam nos bares do edifício, nas livrarias e sebos, e principalmente na Cantina do Lucas, local muito presente nas histórias sobre o grupo. Ali também funcionou o Berimbau Club, casa de jazz e bossa nova que tinha nas paredes pôsteres de Miles Davis, um dos nomes mais citados como influência na música do Clube da Esquina. No local se apresentaram Nivaldo Ornellas, Helvius Villela, Pascoal Meirelles, Paulo Braga, Aécio Flávio e Ildeu Soares, músicos importantes da geração anterior ao grupo estudado por terem sido uma grande influência, e até Milton e Wagner Tiso, recém-chegados de Três Pontas ${ }^{218}$.

Tendo tratado de como as canções do Clube da Esquina tematizam o cenário político e cultural da década de 70, é possível discutir se o Clube da Esquina é ou não um movimento. Para isso, é importante analisar a relação do grupo com a mídia, considerada fraca no momento de auge do mesmo. Inicio neste ponto por achar interessante o fato de que esses mesmos meios de comunicação social, atualmente, no aniversário de 40 anos do disco Clube da Esquina, têm falado muito no "movimento", termo usado frequentemente e sem nenhuma problematização nas reportagens sobre a efeméride ${ }^{219}$.

\footnotetext{
${ }^{216}$ Idem, p. 113.

${ }^{217}$ MUSEU CLUBE DA ESQUINA. Guia turístico de Belo Horizonte: roteiro Clube da Esquina/ Museu Clube da Esquina - Belo Horizonte, 2011, p. 50.

${ }^{218}$ MUSEU CLUBE DA ESQUINA. Guia turístico de Belo Horizonte: roteiro Clube da Esquina/ Museu Clube da Esquina - Belo Horizonte, 2011, p. 46.

${ }^{219}$ Também é interessante relatar aqui que apesar de estar sendo muito divulgado, o aniversário de 40 anos do álbum tem poucas comemorações agendadas. As divulgadas até então contam com poucos integrantes, a maioria apenas com Milton Nascimento e Lô Borges.
} 
Essa relação começa, como vimos, pela própria figura de Milton Nascimento, então o mais famoso do grupo, mas que nunca quis para si a posição de porta-voz. Em matéria publicada pelo jornal Estado de Minas no ano de lançamento do disco Clube da Esquina, ele é apresentado como "esfinge, enigmático, introvertido. O artista que só fala através de sua música, uma música diferente, em que se fundem caracteres eruditos e folclóricos, e que abre caminhos novos para a MPB, rompendo limites e confinamentos 220 ,"

Nessa fala me interessa não apenas a visão, ainda hoje difundida, de Milton como um artista recolhido, quieto, mas também a afirmação de que é "só" na sua música que ele costuma se colocar, e da marcação desta como uma produção que traz inovações para a música popular brasileira.

Retomo então o ponto em que Ana Maria Bahiana e Miguel Jost falam sobre a valorização do artista como formador de opinião, como voz de uma geração ou porta-bandeira das causas nacionais. Quando digo, então, que Milton Nascimento e os demais músicos do Clube da Esquina não tiveram esse tipo de atuação, estou me referindo justamente à ligação deles com a mídia, que não era forte naquele momento. Milton e seus companheiros têm sim uma importância como formadores de opinião, mas essa se dá através de sua música, inclusive levando suas ideias para além das fronteiras nacionais.

Também é importante pensar que a situação política daquele momento, com o arrocho da ditadura militar, perseguições, prisões, assassinatos e exílios, pode ter sido um fator importante para que o grupo não fizesse declarações sobre o assunto. A escolha foi tratar das questões políticas em sua música, mas nunca reivindicando para si o papel de formador de opinião, falando desses assuntos fora do nível musical. O que os artistas do Clube da Esquina pensavam sobre o momento político vivido no Brasil e no mundo está nas canções.

Andar por avenidas enfrentando o que não dá mais pé/ juntar todas as forças pra vencer essa marél o que era pedra vira homem/ e o homem é mais sólido que a marééc

\footnotetext{
${ }^{220}$ BUENO, Andréa dos Reis Estanislau (org.). Coração americano: 35 anos do álbum Clube da Esquina. Belo Horizonte: Prax, 2008, p. 27.

${ }^{221}$ Trecho da canção Saídas e Bandeiras $\mathbf{n}^{\mathbf{0} 2}$, de Milton Nascimento e Fernando Brant, álbum Clube da Esquina, 1972.
} 
Sobre a relação entre postura política e produção musical, a comparação feita por

Caetano Veloso toca num ponto que eu gostaria de desenvolver:

Tropicália ou Panis et Circensis abre com uma composição de Gil e Capinan chamada "Miserere nobis", em cuja letra reconheço o embrião da poética mineira dos anos 70: as referências católicas, as imagens nobres envolvendo um compromisso político mais pressuposto do que explicitado, a dicção solene. Num nível sempre extraordinariamente mais alto do que seus seguidores, Capinan prefigurou toda a lírica "participante" pós-tropicalista ${ }^{222}$ (grifo meu).

O ponto de Caetano se relaciona com uma das primeiras conclusões a que cheguei durante a pesquisa. Numa comparação entre a tropicália e o Clube da Esquina, uma diferença fundamental é o que ele está chamando de "compromisso mais pressuposto do que explicitado", que está relacionado com a postura pouco midiática do Clube da Esquina, com a forma de tocar em assuntos de maneira menos explícita não só na vida, mas também na arte. Se a tropicália tem um discomanifesto e seus integrantes estavam sempre opinando sobre os rumos da música popular no Brasil, dizendo o que achavam que devia ou não ser incorporado ou valorizado, esse é um comportamento que não se vê no Clube da Esquina naquele momento.

Ainda em comparação com o movimento tropicalista, vejamos a análise de Santuza Cambraia Naves sobre a música popular brasileira nos anos 70 , que, segundo a autora, "dá continuidade à maneira tropicalista de desconstruir a canção ${ }^{223}$ ". A desconstrução da canção, segundo Naves, seria o fim do privilégio da correspondência entre música e letra no processo de composição, a impossibilidade, que surge a partir do tropicalismo, de entender certos fenômenos musicais apenas por seus elementos poético-musicais ${ }^{224}$.

Ao contrário, portanto, de um disco de bossa nova, que por si só é revelador do estilo musical, perde-se muito da estética tropicalista se a experiência com o movimento se restringe à musicalidade. O Tropicalismo, para ser entendido, requer não só a fruição dos discos e de suas capas igualmente conceituais -

\footnotetext{
${ }^{222}$ VELOSO, Caetano. Verdade Tropical. São Paulo: Companhia das Letras, 1997.

${ }^{223}$ NAVES, Santuza Cambraia. Canção popular no Brasil: a canção crítica. Rio de Janeiro: Civilização Brasileira, 2010, p. 120.

${ }^{224}$ Idem, p. 96.
} 
criadas por artistas como Rogério Duarte e Hélio Oiticica -, como também a análise de seus espetáculos ${ }^{225}$.

Pensando o Clube da Esquina nesses termos, creio que ele esteja mais próximo da bossa nova do que do tropicalismo, porque é um fenômeno que tem na canção sua unidade significativa. As capas de discos e os shows do grupo reforçam as informações estéticas de sua música, mas não são imprescindíveis para a compreensão desta.

Sobre aspectos performáticos, eles não me pareceram ser de grande importância para o Clube da Esquina. Parto do conceito de performance de Paul Zumthor, que afirma que este está relacionado ao "momento decisivo em que todos os elementos cristalizam em uma e para uma percepção sensorial - um engajamento do corpo $^{226 "}$.

Nas entrevistas feitas e depoimentos encontrados em diversas fontes, pouco se falou sobre as apresentações do grupo, sobre esses elementos corporais que comunicam. Registro aqui essas raras falas:

Danilo Caymmi tocou rapidamente no assunto ao comentar a turnê feita após o lançamento do álbum Clube da Esquina 2, em que "estádios de futebol ficaram lotados em diversas cidades do país ${ }^{227}$,", mas nada falou sobre a forma como o grupo se apresentava no palco.

Em seu livro de memórias, Márcio Borges também poucas vezes toca no assunto. Sobre o show de estreia do álbum Clube da Esquina, no Rio de Janeiro, ele conta:

Não sei com qual intenção, talvez reproduzir as montanhas de Minas, alguém espalhou pelo palco uns montinhos de cupim, ridículos e sem sentido. Os músicos se acotovelavam por entre os montinhos. (...) O show teve início. Bituca estava sóbrio. Etney e Ivanzinho eram os dois contra-regras. Nos shows de Bituca, cada um queria ser mais bicha do que o outro. Com trejeitos muito eficientes, punham tudo nos lugares, violão, instrumentos, copinhos d'água e copinhos de uísque, dependendo do banquinho. Para esse show haviam regulado estritamente o consumo de álcool no camarim. (...) Beto Guedes acometido de um acesso de vergonha e timidez, aquele frangote

\footnotetext{
${ }^{225}$ Idem.

${ }^{226}$ ZUMTHOR, Paul. Performance, recepção, leitura. São Paulo, Cosac Naify, 2007, p. 18.

${ }^{227}$ Danilo Caymmi em depoimento concedido a esta pesquisa.
} 
de Montes Claros, tocou grande parte das músicas de costas para o público, procurando sempre se postar de frente para algum dos músicos. O mais tarimbado era Wagner Tiso, milhares de bailes, competente, tranqüilo, afável, bemhumorado, ligeiramente embriagado. Lô, logo no início de sua parte afundou a cabeça no pescoço e só olhou para as próprias mãos, enquanto tocava violão e guitarra. Mesmo Bituca cantou nervoso, esqueceu algumas letras. O Som Imaginário se atrapalhou em algumas convenções de entrada e saídas de solos. Estréia sofrível ${ }^{228}$.

Márcio também conta sobre um show anterior, de Milton com o Som Imaginário $^{229}$, em que o líder do grupo estava tão bêbado que ao entrar no palco não conseguiu dizer uma palavra, perdeu o equilíbrio e caiu na frente de uma grande plateia. O guitarrista Fredera então fez um discurso no qual, "por artes da retórica, convenceu a platéia de que o porre de Bituca era, sei lá, ideológico ${ }^{230 \text { ". }}$

Fica em destaque nesses trechos que a performance, no sentido corporal, não era uma preocupação do grupo, algo que envolvia um preparo por parte deles. Era importante para eles, segundo alguns depoimentos, o desempenho com os instrumentos, que fossem tocados corretamente, o que também poderia ser entendido como parte da performance, mas não aqui, em que uso a ideia de corporalidade, de aspectos que estão fora da unidade da canção, para pensar na importância desta como elemento estético. E mesmo essa preocupação com a execução dos instrumentos tem suas particularidades, como conta Luiz Henrique Assis Garcia:

A liberdade dos músicos executarem quaisquer instrumentos(inclusive os que não eram sua especialidade) permitiu que Lô Borges aparecesse tocando surdo em Cravo e Canela, Beto Guedes tocando baixo e carrilhão em San Vicente, Nelson Angelo ao piano em Pelo Amor de Deus, e assim por diante. A atuação nas faixas dependia da própria ordem de chegada no estúdio ${ }^{231}$.

\footnotetext{
${ }^{228}$ BORGES, Márcio. Os sonhos não envelhecem: Histórias do Clube da Esquina. São Paulo: Geração Editorial, 2009, p. 271.

${ }^{229}$ A banda Som Imaginário, formada para acompanhar Milton Nascimento, contava com Fredera, Luiz Alves, Tavito, Robertinho Silva e Zé Rodrix.

${ }^{230}$ Idem, p. 265.

${ }^{231}$ GARCIA, Luiz Henrique Assis. Coisas que ficaram muito tempo por dizer: O Clube da Esquina como formação cultural. Dissertação apresentada ao Curso de Mestrado do Programa de PósGraduação do Departamento de História da Faculdade Filosofia e Ciências Humanas da Universidade Federal de Minas Gerais, 2000, p. 30.
} 
Se entendemos a voz como um desses elementos performáticos, existe sim uma questão fundamental para entender a produção analisada. A voz de Milton Nascimento, uma de suas características mais marcantes e que coleciona admiradores, é um elemento primordial para a compreensão dessa música. De grande potência e timbre incomum, usada muitas vezes em falsete e de maneira virtuosa, colocada à frente dos instrumentos nos discos analisados em alguns momentos, é considerada uma das mais bonitas e marcantes da música popular brasileira e traz às canções do Clube da Esquina uma carga dramática muito grande, dando mais força às letras.

Vejamos algumas teses de Paul Zumthor sobre a voz:

Primeira tese: a voz é o lugar do simbólico por excelência; mas um lugar que não pode ser definido por outra forma que por uma relação, uma distância, uma articulação entre o sujeito e o objeto, entre o objeto e o outro. A voz é, pois, inobjetivável. Segunda tese: a voz, quando a percebemos, estabelece ou restabelece uma relação de alteridade, que funda a palavra do sujeito. Terceira tese: todo objeto adquire uma dimensão simbólica quando é vocalizado ${ }^{232}$.

As teses mostram a importância da voz como elemento que significa e que revela alteridades e tratam da dimensão simbólica adquirida por um objeto, como as letras das canções do Clube da Esquina, no caso analisado, quando vocalizados.

No entanto, se estamos pensando a performance como elementos extra musicais, exclui-se aí a voz, porque esta é constituinte da canção como unidade. Reforço então a ideia de que esses elementos não são fundamentais para entender a música do Clube da Esquina. São importantes como registro e para entender a estética do grupo, mas não primordiais para essa compreensão.

A partir daí e tendo destacado o modo como a canção do Clube da Esquina tematiza assuntos importantes nos contextos político e cultural de sua época e as reflexões dos vários integrantes do grupo sobre sua própria música, acredito ser possível problematizar a ideia de "movimento".

Sobre o conceito de "movimento", parto do trabalho de Renato Poggioli, em que ele explica o termo diferenciando-o de "escola". Escola, para o autor, é usado

${ }^{232}$ ZUMTHOR, Paul. Performance, recepção, leitura. São Paulo, Cosac Naify, 2007, p. 83. 
mais frequentemente na história das artes plásticas, porque se refere à importância maior das técnicas e aprendizado. Já o movimento geralmente é chamado assim por seus próprios atores ${ }^{233}$.

Where the school pressupposes disciples consecrated to a transcendent end, the followers of a movement always work in terms of na end imanente in the movement itself. The school is inconceivable outside the humanistic ideal, the idea of culture as a thesaurus. The movement, instead, conceives of culture not as an increment but as a creation - or, at least, as a center of activity and energy ${ }^{234}$.

A movement is constituted primarily to obtain a positive result, for a concrete end. The ultimate hope is naturally the success of the specific movement or, on a higher, broader level, the affirmation of the avant-garde spirit in all cultural fields ${ }^{235}$.

Ou seja, um movimento tem um fim, um objetivo, parte de um grupo que traz propostas de mudanças, que são apresentadas no que o autor chama de manifestos e programas. Dentre outros motivos, por não haver por parte dos integrantes do grupo uma explicitação desses objetivos ou propostas, adianto que não considero o Clube da Esquina um movimento.

Ivan Vilela, um dos autores que defendem a ideia de que o fenômeno estudado é um movimento, traz argumentos bem elaborados, com cujo conteúdo eu concordo, além de uma análise primorosa das canções e da ressonância do Clube da Esquina na história da música, não apenas brasileira, mas internacional. No entanto, considero equivocada a conclusão a que o autor chega, principalmente porque percebo em sua análise uma ideia de que se um fenômeno musical não é reconhecido como um movimento, isso diminui seu valor dentro da história da música, ponto do qual discordo.

A história da MPB foi sempre escrita por jornalistas, historiadores, cientistas sociais e críticos literários. Isto, se por um lado, articula o fenômeno musical a outras artes e o supõe sob diferentes ângulos trazendo um novo recorte ao se olhar para diferentes aspectos que compõem este fenômeno musical, por outro, deixou à deriva a questão estritamente musical. Achamos que tal perspectiva, historicamente, favoreceu ao não-

\footnotetext{
${ }^{233}$ POGGIOLI, Renato. The Theory of the avant-garde. Massachussets: The Belknap Press of Harvard University Press Cambridge, 1981, p. 18.

${ }^{234}$ Idem, p. 20.

${ }^{235}$ Idem, p. 25.
} 
reconhecimento do Clube da Esquina como um Movimento Musical $^{236}$.

A partir daí Vilela vai alegar que por sua qualidade e inovação musical, o Clube da Esquina deve ser considerado um movimento. Entretanto, como vimos, um movimento tem mais do que inovações estéticas, ou melhor, trabalham essas inovações como propostas a serem discutidas e incorporadas culturalmente. Ele tem objetivos concretos, propostas a apresentar e alcançar, o que não acontece com o Clube da Esquina.

Vejo aqui a necessidade de dar voz aos próprios produtores da música analisada, a fim de saber se eles se consideravam parte de um movimento. Vejamos o que diz Flávio Venturini:

Eu não acho que seja um movimento no sentido político, ideológico. Eu acho que é estético. Foi uma coisa muito diferente de tudo no Brasil. Eu acho que em termos musicais, literários foi uma coisa muito diferente, muito original, muito rica que Minas deu ao Brasil, ao mundo ${ }^{237}$.

Márcio Borges me fez declaração parecida, sobre não ser um movimento no sentido político, e fala sobre isso em seu livro de memórias:

O fato é que, para uma mentalidade conservadora como a mineira, era mais fácil aceitar uma revolução na harmonia musical, afinal uma coisa que atingia apenas os estritamente interessados, do que aceitar uma revolução no comportamento geral, mil vezes mais perigosa e de consequiências mais imprevisíveis. Segundo essa mesma mentalidade, tudo o que pudesse ser qualificado de "desbunde" era digno de reproches e, por extensão, aquele lado Tom Zé e Wally Sailormoon da Tropicália, aquele lado Navilouca e Hélio Oiticica, só mesmo Neville e Túlio Marques, que haviam sido amigos do pintor em New York, é que gostavam daquilo. Minto: meus mais radicais amigos da luta armada também gostavam. Vá querer entender uma confusão daquelas ${ }^{238}$ !

E completa:

Eu diria que a presença do Clube da Esquina na história da moderna música popular brasileira, que vem da bossa nova e

\footnotetext{
${ }^{236}$ VILELA, Ivan. Nada Ficou Como Antes. Revista USP, v. 87, p. 14-27, 2010, p. 2.

${ }^{237}$ Flávio Venturini, músico integrante do Clube da Esquina, em depoimento ao Museu Clube da Esquina: www.museudapessoa.net/clube/.

${ }^{238}$ BORGES, Márcio. Os sonhos não envelhecem: Histórias do Clube da Esquina. São Paulo: Geração Editorial, 2009, p. 195.
} 
passa pela tropicália, foi um parêntesis. Um parêntesis provinciano que aconteceu de forma provinciana, mas que pela sua qualidade estética conseguiu romper com as fronteiras da "música de província", que era tocada só nos festivais em Belo Horizonte e sair desse âmbito para ser conhecida nacional e internacionalmente ${ }^{239}$.

Vejamos o depoimento de Cafi, principal fotógrafo do Clube da Esquina:

Eu acho o seguinte: o que os baianos fizeram com o tropicalismo, um movimento estético que era formal, extremamente formal - usando música de carnaval, outras coisas - não é necessariamente, intrinsecamente composto de músicas boas no sentido da qualidade. Já os mineiros tinham isso, quase que um rebuscamento maior, ligado ao próprio Barroco mineiro, mais rebuscado. Então musicalmente é um encontro, não é uma postura; a postura seria a de ter conseguido paralisar em um momento $\mathrm{X}$, ou fotografar um momento $\mathrm{X}, \mathrm{o}$ que vinha acontecendo com a música mineira em relação à música internacional, dos Beatles. Quer dizer, qual a leitura que os mineiros fizeram desse novo momento? Mas era um movimento basicamente em cima de músicos, de músicos bons que já transavam a coisa do jazz, a coisa da bossa nova, então tem uma qualidade musical muito grande. Mas nunca houve uma formalização muito forte, em termos de uma postura estética. A postura estética surgiu pela maneira de ser e pela maneira de se transar, às vezes até muito mais em cima dessa coisa da amizade ${ }^{240}$.

E Wagner Tiso afirma que a música de Milton passou a ser ouvida por mais gente com o Clube da Esquina, e que para que isso acontecesse, Lô Borges e Beto Guedes foram importantes. Sobre o assunto, Lô Borges comenta:

Flertamos muito mais com uma juventude, que era carente de alguma música nova no Brasil, de artistas como Caetano e Chico. O Milton com a turma dele teve que segurar a história de preencher um espaço que estava vazio. Alguns estavam no exílio. Aumentou o número [de ouvintes de Milton] porque tinha uma demanda. A música passou a flertar com outra sonoridade. Não tinha muito na música brasileira. Milton era MPB clássico e o Clube trouxe gente de outra sonoridade, de Beatles e Rolling Stones. Era uma escolha estética, e não política. Todas as guitarras eram contribuição estética. (...) E não faço ideia de onde tirei aquelas músicas, era admirador de tantas coisas. Fiz a música que meu coração abertamente sentia. É um conjunto de influências e não sei quais são as principais.

${ }^{239}$ BORGES, Márcio. O Clube da Esquina. In: DUARTE, Paulo Sérgio e NAVES, Santuza Cambraia (orgs.). Do Samba-Canção à Tropicália. Rio de Janeiro: Relume Dumará: FAPERJ, 2003, p. 174.

${ }^{240}$ Cafi, fotógrafo integrante do Clube da Esquina, em depoimento ao Museu Clube da Esquina: www.museudapessoa.net/clube/. 
Foi novidade, eu não conhecia meu lado compositor. Eu não me perguntava o que era que eu estava fazendo ${ }^{241}$.

É importante destacar que o discurso de naturalidade por parte de alguns integrantes é muito forte, como se tudo acontecesse por acaso, ingenuamente. Existe no depoimento de participantes do Clube da Esquina uma tentativa de naturalização do processo de composição e produção musical, o que é fundamental para a discussão que proponho neste momento. É significativa também a separação entre estética e política e que a maior valorização da primeira seja um ponto comum entre essas falas.

Miguel Jost Ramos afirma que a década de 1970 não teve um movimento organizado com propostas estéticas definidas, e a impossibilidade de reunir a produção musical deste período sob alguma classificação que funcione por critérios de semelhança é um índice de que muitos aspectos e temas podem servir para refletir sobre os anos $70^{242}$.

Considero a afirmação do autor fundamental para entender a produção estudada aqui. O Clube é inovador esteticamente e se tornou uma referência internacional, mas além de não ter a estrutura de um movimento, não me parece que os integrantes buscavam ser um. Com exceção de Ronaldo Bastos, todos os que entrevistei disseram não se perceberem como um movimento.

Não vejo o Clube da Esquina como movimento porque acredito ser possível afirmar que seus integrantes nunca operaram com essa estrutura, não quiseram ser um movimento. Inovaram, mas não era uma preocupação que suas inovações fossem incorporadas, não tinham uma proposta estética definida e nem buscavam ter. Assim como afirma Ronaldo Santos em relação à Nuvem Cigana, o Clube da Esquina também não tinha programa, partido ou palavra de ordem. De tudo o que listamos aqui como características da música do Clube da Esquina, nada pode ser assegurado como absoluto, como regra.

A própria desconstrução do nome "Clube da Esquina" é uma das grandes surpresas que tive durante a pesquisa e a maior concordância, se não a única, entre

\footnotetext{
${ }^{241}$ Lô Borges em depoimento concedido a esta pesquisa.

${ }^{242}$ RAMOS, Miguel Jost. Re(Des)organizando o movimento: Um Olhar sobre a música popular brasileira na década de 70. Dissertação de Mestrado. Rio de Janeiro: PUC-Rio, Abril de 2007, p. 9.
} 
todos que entrevistei, e mostra como a fragilidade que existe em pensar esse objeto como movimento.

Uma das perguntas iniciais desse trabalho era sobre o nome do grupo. Tendo como proposta tentar entender o porquê de "Clube" e de "Esquina" e o que esse nome poderia contar sobre a música do grupo, questionei os entrevistados sobre o mesmo. Antes de ser referência ao grupo, o nome "Clube da Esquina" foi título de uma canção de Milton Nascimento, Lô e Márcio Borges, que partiu da forma como sua mãe se referia à esquina onde Lô passava grande parte do tempo acompanhado de seus amigos. No entanto, nas entrevistas, todos foram unânimes em dizer que nunca existiu um clube e que a esquina era mais frequentada por Lô e os amigos de sua idade (Milton e Márcio são mais velhos do que Lô e não faziam parte do mesmo círculo de amizades) do que pelos músicos do grupo.

As frases de Fernando Brant e Nelson Angelo sintetizam o que ouvi dos entrevistados: "Nunca fomos um clube, ninguém tinha carteirinha. E a esquina era do Lô ${ }^{243 " . ~ " N i n g u e ́ m ~ e n t r o u ~ o u ~ s a i u ~ d o ~ C l u b e ~ d a ~ E s q u i n a ~ p o r q u e ~ n a ̃ o ~ e ́ ~ u m ~}$ Clube". "Clube da Esquina" apareceu, portanto, apenas como um nome, uma forma de designar o grupo.

Mas como foi se mostrando comum durante a pesquisa sobre um grupo com uma produção tão grande e um número significativo de integrantes, aqui também há um ponto de tensão. Contrastando com a desmitificação do nome do grupo, há atualmente na esquina citada, entre as ruas Divinópolis e Paraisópolis, em Santa Teresa, duas placas colocadas pelo Museu do Clube da Esquina. Em uma delas, nos moldes das outras 24 que estão em diversos locais da cidade de Belo Horizonte, lê-se: "Clube da Esquina: O termo foi criado e empregado pela primeira vez por Maria Fragoso Borges para nomear esta esquina onde jovens moradores das redondezas se reuniam no final dos anos 60. A turma original era formada por Lô e Yê Borges, Joãozinho, Amauri, Landinha, Dago, João Luiz, Beto Ronca Ferro e dezenas de outros jovens".

A placa maior traz a letra da canção Clube da Esquina e os dizeres: "Aqui neste pedaço de chão se sentaram meus irmãos de sangue e de som, Marilton, Milton,

${ }^{243}$ Fernando Brant em entrevista concedida para esta pesquisa. 
Lô, Ronaldo, Fernando, Beto, Toninho, Wagner, Tavinho, Naná e tantos outros- e juntos, instrumentos à mão, sonhamos com a liberdade e a união entre todos os homens. Márcio Borges". Liberdade e união são, como vimos, valores tematizados de maneira recorrente nas músicas do Clube da Esquina, fazem parte dos discursos musical e "institucional".

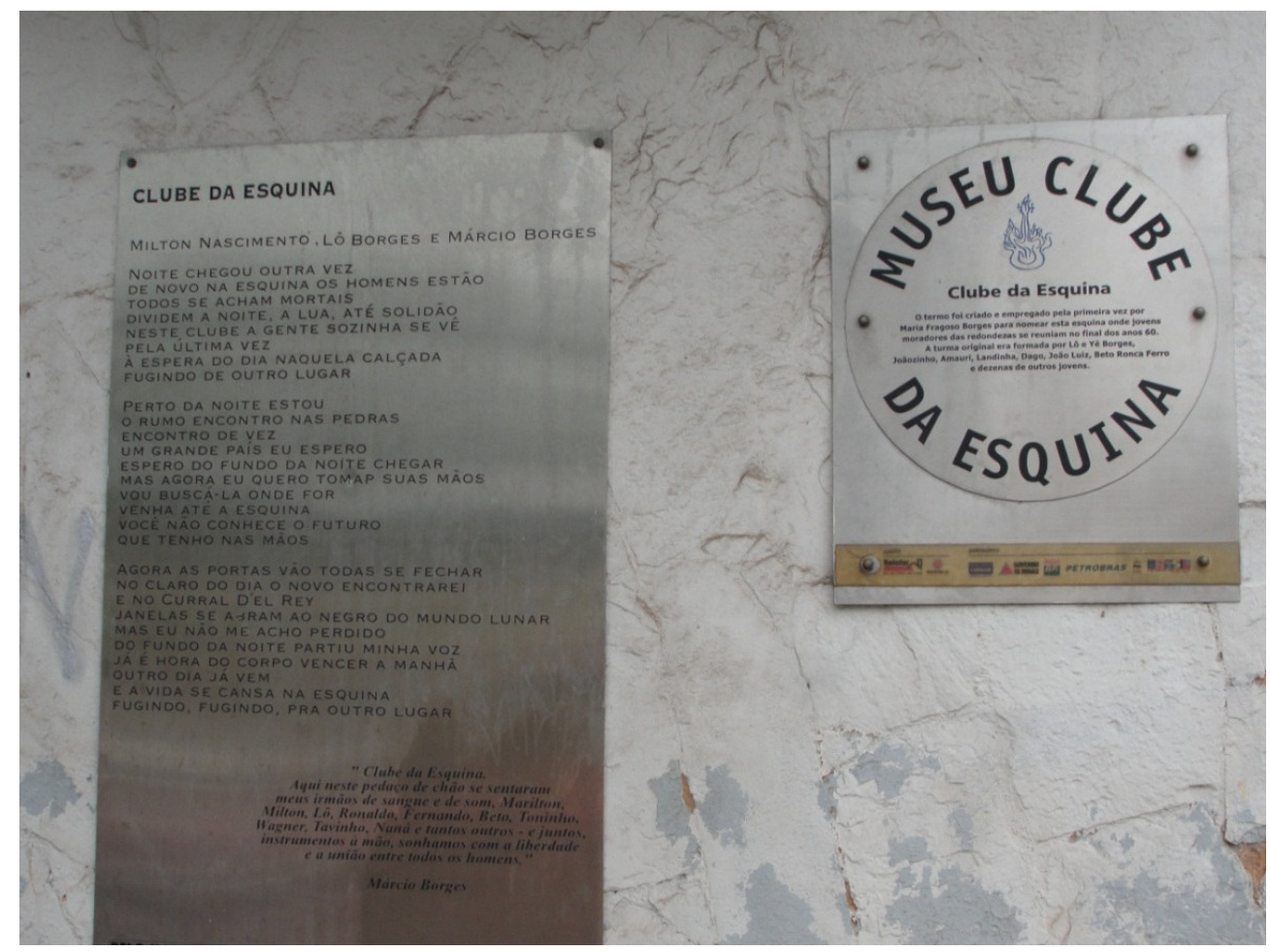

Por essa e todas as questões que exponho nesse capítulo, acredito ser possível dizer que a politização da música do Clube da Esquina não é nem tão naturalizada como alguns integrantes querem fazer crer, mas também não é um projeto ${ }^{244}$, como colocado por outros. Esses temas estão presentes porque faziam parte do contexto sociocultural e também pela vontade e necessidade que os compositores tinham de tratar deles. E por temas politicamente importantes entendo não apenas os tratados aqui nesse capítulo, em que falo do cenário político, mas todas as escolhas feitas pelo grupo, afinal, contrariando a separação entre política e estética feita por alguns, creio que toda escolha artística manifeste também uma postura política.

\footnotetext{
${ }^{244}$ Por esse motivo, preferi usar o termo "produção musical" no lugar de "projeto" algumas vezes no texto, para que não passasse a ideia de algo concebido como um programa, e sim de um conjunto de obras.
} 


\section{3. "Tenho séculos de espera nas contas da minha costela". O Clube da Esquina e os grupos étnicos ${ }^{245}$}

Quando trata de aspectos designados modernos, Paul Gilroy ${ }^{246}$ critica os estudos das Ciências Sociais que ignoram a música, mostrando que ela é fundamental para entender as respostas negras à modernidade. Embora o autor trate especificamente da música negra, suas colocações se mostram importantes para pensar as relações entre música e grupos étnicos, questão que me pareceu fundamental neste trabalho.

Através de uma discussão da música e das relações sociais que a acompanham, desejo esclarecer alguns dos atributos distintivos das formas culturais negras que são, a um só tempo, modernas e modernistas. São modernas porque têm sido marcadas por suas origens híbridas e crioulas no Ocidente; porque têm se empenhado em fugir ao seu status de mercadorias e da posição determinada pelo mesmo no interior das indústrias culturais; e porque são produzidas por artistas cujo entendimento de sua própria posição em relação ao grupo racial e do papel da arte na mediação entre a criatividade individual e a dinâmica social é moldado por um sentido da prática artística como um domínio autônomo, relutante ou voluntariamente divorciado da experiência da vida cotidiana ${ }^{247}$.

Todas as características citadas pelo autor como parte dessas manifestações culturais negras modernas podem ser comparadas com as encontradas na música do Clube da Esquina. O hibridismo de influências e temas e o entendimento dos integrantes do grupo em relação à sua posição social, já mencionados nesse trabalho, se somam a um nível de experimentação muito grande que em nada lembra as melodias comerciais que existiam naquele momento. No discurso dos integrantes do grupo, existe a fala recorrente sobre uma vontade de fazer música

\footnotetext{
${ }^{245}$ É importante apontar, por ter escolhido usar o termo "etnias", que este não era comum no Brasil nos anos 70, de quando data o objeto de pesquisa. Os termos "raças" ou "povos" eram os correntes naquele momento. Apenas com a entrada de novas agendas políticas nos anos 80 passou-se a usar o termo "etnias". Ele foi escolhido aqui por ser o que se encaixa melhor para tratar dos grupos tematizados, ou seja, negros, índios e latinos.

${ }^{246}$ GILROY, Paul. O Atlântico Negro. Modernidade e dupla consciência. São Paulo, Rio de Janeiro: Editora 34/Universidade Cândido Mendes, 2001, p. 159.

${ }^{247} \mathrm{Idem}$.
} 
de acordo com sua sensibilidade, e não apenas pensando em entrar para as paradas de sucesso. Fernando Brant diz:

Eu acho que o Clube foi uma coisa feita com uma coisa muito criativa e ao mesmo tempo feita com muita alegria e muito companheirismo. A gente estava querendo fazer uma coisa bonita. Até o Edu Lobo escreveu outro dia sobre um disco deles. Tem um monte de compositor, mas você não está preocupando em vender, você quer fazer uma coisa boa, boa pra você e pras pessoas que gostam de música também. Então, a preocupação da gente era essa: fazer uma coisa legal ${ }^{248}$.

Já Lô Borges afirma: "Eu não tinha preocupação nenhuma com vender. Era só curtição. Bastava comover quem estava participando. O público que eu queria atingir era quem trabalhava no disco" 249 .

Mesmo sendo impossível ignorar o mercado, já que os músicos tinham na venda de disco e nos shows sua fonte de renda, os depoimentos exemplificam como a preocupação deles estava muito mais relacionada com a sensibilidade e a qualidade musical do que com fatores comerciais, o que está relacionado à fuga do status de mercadoria comentada por Gilroy.

Para Santuza Cambraia Naves, a tropicália não apenas substituiu o "compromisso nacional por uma articulação do local com o global ${ }^{250 ", ~ q u e s t a ̃ o ~ j a ́ ~ d i s c u t i d a ~ n e s s e ~}$ trabalho em relação ao Clube da Esquina, mas também adotou uma "perspectiva política mais ampla, não restrita ao sistema político partidário e de certa forma ligada ao universo contracultural ${ }^{251}$ ". A autora cita a crítica tropicalista ao deslumbramento com o avanço industrial e ao modelo familiar instituído pelas famílias burguesas. Retomando a ideia da "politização do cotidiano", que considero estar relacionada com essa perspectiva política mais ampla de que fala a autora, vejo no Clube da Esquina a denúncia das desigualdades de condições e do sofrimento e subjugo comuns à história de três grupos, negros, índios e latinos, como tema importante.

\footnotetext{
${ }^{248}$ Fernando Brant em depoimento ao Museu Clube da Esquina: www.museudapessoa.net/clube/.

${ }^{249}$ Lô Borges em depoimento concedido a esta pesquisa.

${ }^{250}$ NAVES, Santuza Cambraia. É proibido proibir: contracultura e tropicália. In: FICO, Carlos e ARAUJO, Maria Paula (org.). 1968: 40 anos depois. Rio de Janeiro, 7 Letras, 2009, p. 123.

${ }^{251} \mathrm{Idem}$.
} 
Meus gritos afro-latidos/ Implodem, rasgam, esganam/ E nos meus dedos dormidos/ A lua das unhas ganem/ E daí? / (...) Tenho séculos de espera/ Nas contas da minha costela/ Tenho nos olhos quimeras/ Com brilho de trinta velas/ E daí ?252

Guaicurus Caetés Goitacazes/ Tupinambás Aimorés/ Todos no chão/ Guajajaras Tamoios Tapuias/ Todos Tumbiras Tupis/ Todos no chão/ A parede das ruas/ Não devolveu/ Os abismos que se rolou/ Horizonte perdido no meio da selva/ Cresceu o arraial $^{253}$

Enquanto se esperava/ eu estava em San Vicente/ enquanto acontecia/ eu estava em San Vicente/ coração americano/ um sabor de vidro e corte ${ }^{254}$

As letras falam de ausências e espera por algo que pertencia a esses sujeitos e não foi devolvido. As quimeras e o horizonte foram perdidos no passado e essa perda é parte da história do homem que grita seu "afro-latido", assim como dos Guaicurus, Caetés e outros grupos indígenas, e dos corações americanos.

A relação entre passado e presente pode ser muito reveladora e se conecta com algumas teorias propostas por Gilroy. Para o autor, pode-se afirmar que certas formas culturais expressivas negras, como a música, são modernas e ocidentais, mas é preciso ver que elas estão além dessas duas características:

Essas formas culturais e os diálogos para os quais elas contribuem são uma refutação dinâmica das sugestões hegelianas de que o pensamento e a reflexão superaram a arte e que a arte é oposta à filosofia como forma mais inferior, meramente sensual de reconciliação entre a natureza e a realidade finita. A teimosa modernidade dessas formas musicais negras exigiria uma reordenação da hierarquia moderna de Hegel em relação às realizações culturais ${ }^{255}$.

Acredito que a música do Clube da Esquina reforça essa ideia de Gilroy. Assim como ele afirma que tratar de questões do passado reimaginando-as no presente transforma a relação entre a arte e a ciência, uma forma de construção da

${ }^{252}$ Trecho da canção E Daí?, de Milton Nascimento e Ruy Guerra, álbum Clube da Esquina 2, 1978.

${ }^{253}$ Trecho da canção Ruas da Cidade, de Lô Borges e Márcio Borges, Clube da Esquina 2, 1978.

${ }^{254}$ Trecho da canção San Vicente, de Milton Nascimento e Fernando Brant, álbum Clube da Esquina, 1972.

${ }^{255}$ GILROY, Paul. O Atlântico Negro. Modernidade e dupla consciência. São Paulo, Rio de Janeiro: Editora 34/Universidade Cândido Mendes, 2001, p. 159. 
identidade própria da modernidade, podemos dizer que as canções que analisamos também são construídas dentro dessa reimaginação de temas, instrumentos e ritmos considerados antigos.

O fato de um grupo constituído em uma capital brasileira em momento de crescimento econômico e industrial, com o progresso e o avanço como ideais correntes, valorizar ritmos e instrumentos tribais, africanos e da época do colonialismo hispânico e voltar seu olhar para a vida do negro, do índio e do latino, assim como para as consequências da dominação destes, mostra a coerência da colocação de Gilroy quanto à reordenação da hierarquia de Hegel.

No livro Aqui ninguém é branco, Liv Sovik introduz sua tese afirmando que estudar certos aspectos da música popular brasileira permitiu pensar sobre temas como o cosmopolitismo do país, a representação do corpo dançante como emblema da nação, o incômodo causado atualmente pela memória da escravidão, subjetividades brancas e culturas negras ${ }^{256}$. Acredito que esse incômodo citado pela autora esteja presente na música do Clube da Esquina.

Casa iluminada/ portão de ferro, cadeado, coração/ e eu reconquistado/ vou passeando, passeando e morrer ${ }^{257}$

Mesmo não encarando tal questão como projeto político ou cultural, no caso do Clube da Esquina é impossível negar que a forma como tratam o assunto étnico mostra um posicionamento do grupo, uma ideia de que essa é uma questão que não deve ser calada, um anseio de fazer pensar sobre esse assunto. A reação dos críticos ao show de estreia do primeiro disco do grupo foi significativa nesse sentido.

Naturalmente, os críticos foram horríveis. Ficavam querendo comparar Bituca com Caetano e Chico Buarque, não entendiam nada daquele ecumenismo inter-racial, internacional, interplanetário, proposto pelas dissonâncias atemporais de Bituca. Desprezavam os achados de Chopin e o zelo beatlemaníaco do menino Lô. Eu culpava nossas letras, principalmente as minhas, por grande parte daquele fracasso. Só os estudantes gostavam daquilo. O marido da minha tia Alfa (...) disse no tom de quem dá um conselho vital: - Tem que ir no

\footnotetext{
${ }^{256}$ SOVIK, Liv. Aqui ninguém é branco. Rio de Janeiro: Aeroplano, 2009, p. 17.

${ }^{257}$ Trecho da canção Os Povos, de Milton Nascimento e Márcio Borges, álbum Clube da Esquina, 1972.
} 
Chacrinha. Tem que fazer música fácil, de refrão. Tem que parar de fazer essas músicas pra intelectual. Intelectual não vê televisão nem compra disco ${ }^{258}$ (grifos meus).

Vemos no depoimento que tanto a música quanto a letra causaram estranhamento naquele primeiro momento. A grande mistura de temas e referências sonoras e o que o autor chama de "ecumenismo inter-racial, internacional e interplanetário", que entendo como uma interculturalidade, foram rotuladas de "música pra intelectual". Mas mesmo os críticos, que são parte desse grupo dos intelectuais, não aceitaram bem aquela novidade, tentaram compará-la com as referências que tinham até então.

A capa do Clube da Esquina, que é, para Márcio Borges, "o produto mais anticomercial de todos os tempos ${ }^{259,}$, se difere do mais comum na época, que era um título em letras grandes e um close do artista. Obra do fotógrafo Cafi, que fotografou os dois meninos, um negro e um branco, perto da fazenda de Ronaldo Bastos, sentados na estrada, é ousada tanto por não ter nada escrito quanto por trazer duas crianças desconhecidas. Além da alusão ao mundo rural, tão presente na música analisada, também está tratando da convivência entre negros e brancos e acabou virando uma referência a Milton Nascimento e Lô Borges, já que muitas pessoas até hoje pensam que são os dois artistas na infância.

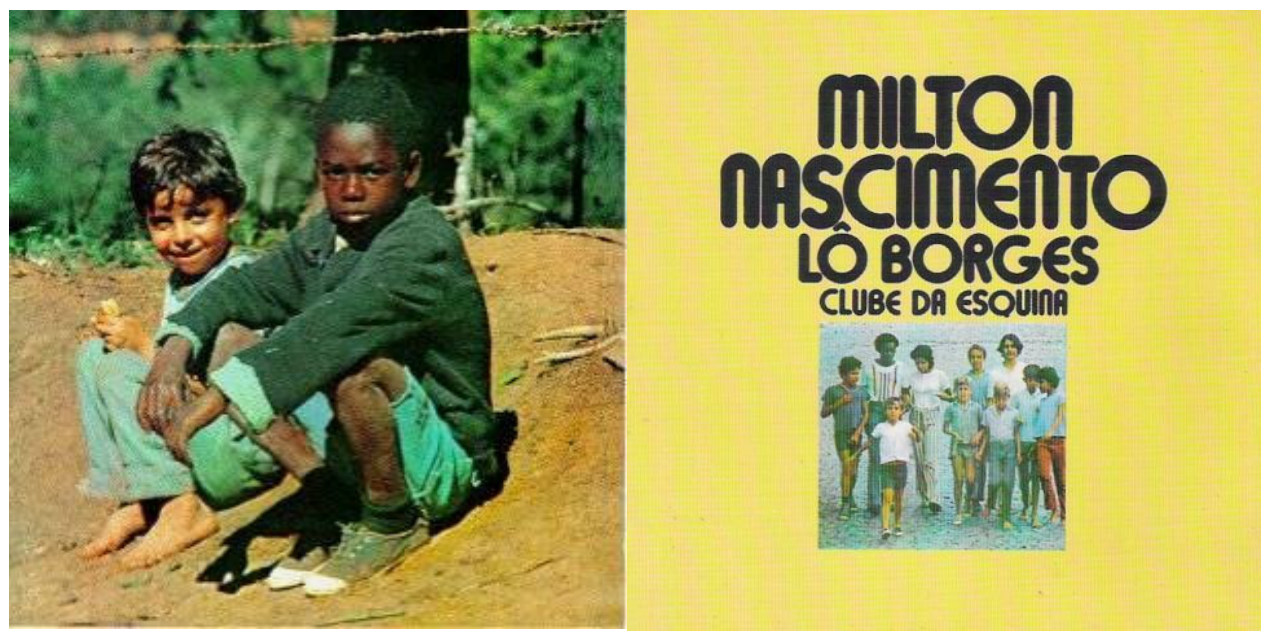

Capa e contracapa do disco Clube da Esquina (1972)

\footnotetext{
${ }^{258}$ BORGES, Márcio. Os sonhos não envelhecem: Histórias do Clube da Esquina. São Paulo: Geração Editorial, 2009, p. 272.

${ }^{259}$ Márcio Borges em depoimento ao Museu Clube da Esquina: www.museudapessoa.net/clube/.
} 
Obrigado pela gravadora a fazer uma contracapa com letreiro, Cafi conta que "a Odeon recomendava botar a contracapa na frente. (...) Nos primeiros 15 dias, era o letreiro que saía nas lojas de discos. Depois de 15 dias, eles foram virando, porque era muito mais inusitado dois meninos sentados na estrada sem nada escrito ${ }^{260,}$.

No ano de 2012, em que são comemorados os 40 anos do álbum, repórteres do jornal Estado de Minas investigaram o paradeiro dos dois meninos fotografados e os encontraram. A capa é apontada como uma das mais famosas da história da música brasileira e a matéria trata da relação dos personagens com a música do Clube da Esquina. Tonho, o menino branco, não conhece a produção e nem sabia que estava na capa do disco. Já Cacau não apenas sabia como possui o álbum em cd e lista Milton Nascimento como um dos músicos que gosta de escutar ${ }^{261}$.

Ao falar sobre aquilo que costumamos chamar de "world music" e as relações que ela implica entre os grupos que produzem essa música e os cientistas que a tornam um produto comercial, Steven Feld, que está neste último grupo, mostra como a questão da diversidade cultural é valorizada nesse meio.

At a historical moment when cultural diversity is both increasingly commodified and becoming a more scarce commodity, anthropological discourse is increasingly engaged with the criticism of state-indigene relations. And as the chaos so recklessly visited upon the others they care to chronicle escalates, anthropologists are increasingly engaged with giving voice people whose validity, indeed, humanity, is denied or silences by the dominant ${ }^{262}$.

Segundo Feld, o termo "world music" surge nos anos 1960 para celebrar e promover a diversidade musical, como uma alternativa "menos desajeitada" para 'etnomusicologia', o termo acadêmico que emergiu em meados dos anos 1950

\footnotetext{
${ }^{260}$ Cafi em depoimento ao Museu Clube da Esquina: www.museudapessoa.net/clube/.

261 A matéria está disponível em: http://www.divirta$\underline{\text { se.uai.com.br/html/sessao_19/2012/03/18/ficha_musica/id_sessao=19\&id_noticia=50783/ficha_m }}$ usica.shtml.

${ }^{262}$ FELD, Steven. From Schizophonia to schimogenesis: the discourses and practices of world music and world beat. In: MARCUS, George E. e MYERS, Fred R. (org.). The traffic in culture: refiguring art and anthropology. University of California Press. Berkeley and Los Angeles, Califórnia, 1995, p. 118.
} 
para referir o estudo de músicas não-ocidentais e de minorias étnicas ${ }^{263}$. Sobre a relação entre a música do Clube da Esquina e esta categoria, ela é comentada por Ivan Vilela, tratando justamente da diversidade de influências encontradas na música do grupo.

No álbum Clube da Esquina, de 1972, o amálgama destes gêneros (o rock, o jazz, a bossa, o clássico, a música regional) foi tão profundo que ficou difícil discernirmos uma ou outra tendência em específico. Nos põe a pensar se este álbum não seria o precursor de um procedimento que, mais de uma década depois, receberia o nome de World Music ${ }^{264}$.

Acredito que a música do Clube da Esquina opere de uma forma parecida com a descrita por Feld. Assim como os antropólogos descritos pelo ele procuram dar voz aos povos dominados, a música analisada aqui também tem essa preocupação, mas contam as histórias com sua própria voz. Vejo nessa preocupação a valorização da diversidade de que o autor nos fala, já que o Clube da Esquina escolhe grupos tão diferentes como tema.

O conjunto de cientistas ao qual Feld pertence atua comercializando a produção musical de um grupo que inicialmente não poderia fazê-lo com seus próprios recursos no contexto em que o autor está escrevendo. Já o Clube da Esquina é o próprio produtor da música que trata das questões desses povos. Não é a ideia discutir aqui as diferenças entre as duas formas, mas perceber os significados da escolha do grupo em tratar desses temas.

Vejamos mais algumas letras que tratam do indígena:

$\mathrm{Na}$ reserva desse índio/ Clamo forte por um rio/ Soprem meus sentidos/ Pela vida de meu filho/ Cuidem bem de minha casa/ Tão cheia, meninos/ Tome conta de aquilo tudo/ Em que acredito/ $\mathrm{E}$ juntem todas minhas cinzas ao poema desse povo ${ }^{265}$

\footnotetext{
${ }^{263}$ FELD, Steven. Uma doce cantiga de ninar para a 'world music'. In: Debates - Cadernos do programa de Pós-Graduação em Música. Rio de Janeiro: Centro de Letras e Artes Unirio, nº8, dezembro de 2005, p. 11.

${ }^{264}$ VILELA, Ivan. Nada Ficou Como Antes. Revista USP, v. 87, p. 14-27, 2010, p. 5.

${ }^{265}$ Trecho da canção Testamento, de Nelson Angelo e Milton Nascimento, álbum Clube da Esquina 2, 1978.
} 
Alertem todos alarmas/ Que o homem que eu era voltou/ A tribo toda reunida/ Ração dividida ao sol $^{266}$

Canoa canoa desce/ No meio do rio Araguaia desce/ No meio da noite alta da floresta/ Levando a solidão e a coragem/ Dos homens que são/ Ava avacanoê $\hat{e}^{267}$

$\mathrm{Na}$ última canção citada, é utilizado um recurso muito comum na música brasileira quando o tema são os índios, que é a língua portuguesa falada de uma forma "indigenizada", com os verbos conjugados na terceira pessoa do singular e a supressão de artigos.

Avacanoeiro prefere as águas/ Avacanoeiro prefere os rios/ Avacanoeiro prefere os peixes/ Avacanoeiro prefere remar ${ }^{268}$

Presente em marchinhas de carnaval, músicas infantis e em diversas outras canções muito conhecidas no universo da música popular brasileira ${ }^{269}$, o recurso aparece tanto como estereotipização da figura do indígena, na tentativa de fazer humor, quanto como denúncia dos maus-tratos sofridos pelos indígenas historicamente e também como forma de marcar uma particularidade do grupo, o que penso ser o caso da canção citada.

Nelson Angelo, um dos compositores, conta que a música foi feita em Manaus, em uma viagem de canoa durante a madrugada. "Como eu não sabia remar direito, fiquei tocando violão. Juntei duas músicas que eu tinha começado e virou Canoa, Canoa $^{270 " . ~ O ~ m u ́ s i c o ~ p e d i u ~ a ~ F e r n a n d o ~ B r a n t ~ q u e ~ f i z e s s e ~ u m a ~ l e t r a ~ f a l a n d o ~ d e ~}$ canoa. Brant pediu ajuda a Tavinho Moura, que sempre pesquisou a música

\footnotetext{
${ }^{266}$ Trecho da canção O Que Foi Feito De Vera, de Milton Nascimento e Márcio Borges, álbum Clube da Esquina 2, 1978.

267 Trecho da canção Canoa, Canoa, de Nelson Angelo e Fernando Brant, álbum Clube da Esquina 2, 1978.

${ }^{268}$ Idem.

${ }^{269}$ Para citar pelo menos um exemplo de cada gênero citado, temos nas marchinhas de carnaval a famosa "Índio quer apito", de Haroldo Lobo (Índio quer apito/ Se não der/ Pau vai comer), nas músicas infantis, um dos maiores sucessos de Xuxa, "Brincar de Índio", de Renam De Moraes e Mauricio Vidal (Índio fazer barulho/ Índio ter seu orgulho) e "Cara de Î́ndio", de Djavan, (Índio quer se nomear/ nome de índio).

${ }^{270}$ Nelson Angelo em depoimento concedido a esta pesquisa.
} 
indígena e informou ao letrista que os Avacanoê tinham um canto especial, que foi ouvido por eles. Danilo Caymmi relata ainda que "pegou uma flauta de madeira que estava de bobeira" e fez a introdução da música, que junto com o toque de um bambu e pios imitando pássaros remete a canções tribais.

Outra canção muito importante para entender a relação do Clube da Esquina com a questão étnica é Casamiento de Negros. Música recolhida e adaptada do folclore chileno por Violeta Parra com estrofe final de Polo Cabrera, ela conta a história de um casamento entre dois negros, em que a noiva morre queimada no dia seguinte à festa. Na história contada, todas as pessoas, objetos e mesmo os ambientes são negros. O ápice acontece quando a noiva parte para o céu e a porta é aberta por São Pedro, que também é negro:

Y ya partió la negrita/ Levitando para el cielo/ Era um dia muy nublado/ Todo se veia negro/ Le abrió La puerta San Pedro/ Que era de los mismos negros ${ }^{271}$

Além da importância da escolha de uma música chilena, o que reforça a ideia já trabalhada aqui de uma união da América Latina, a canção é significativa porque traz a surpresa de um São Pedro negro, personagem muito importante para a Igreja Católica, que é sempre retratado com traços brancos. A canção tem a capacidade de tornar manifesta uma história de um grupo normalmente excluído, como acontece com outras músicas nos dois discos estudados.

Poeira, na noite/ A festa da noite/ Guerreira, estrela da morte/ Festa negra amor/ Mas é tarde ${ }^{272}$

Marinheiros, capitães, negros sobas/ Rei do Congo/ A rainha e seu povo/ As mucamas/E os escravos no canavial/ Amadês senhor de engenho e sinhá/ Traz aqui maracatu nossa escola/ Do Recife nós trazemos/ Com alma/ A nação maracatu/ Nosso tema geral/ Vem do negro esta festa de reis ${ }^{273}$

Quando trata das rebeliões das minorias étnicas e culturais, Octavio Paz afirma que suas "reinvindicações de ordem econômica não são as únicas nem, muitas

\footnotetext{
${ }^{271}$ Trecho da canção Casamiento de Negros, de Violeta Parra e Polo Cabrera, álbum Clube da Esquina 2, 1978.

272 Trecho da canção Estrelas, de Lô Borges e Márcio Borges, álbum Clube da Esquina, 1972.

${ }^{273}$ Trecho da canção Reis e Rainhas do Maracatu, tema dos estudantes do samba de Três Pontas, de Milton Nascimento, Novelli, Nelson Angelo e Fran, álbum Clube da Esquina 2, 1978.
} 
vezes, as centrais. Negros e minorias marginalizadas lutam pelo reconhecimento de sua identidade ${ }^{274 "}$. Pelos argumentos citados neste capítulo, acredito poder afirmar que essa luta citada pelo autor está presente nessa produção musical.

O próprio Milton Nascimento guarda em sua história momentos de exclusão social devido ao fato de ser negro. Em sua formatura no Ginásio, no ano de 1958, ele foi eleito orador da turma e era considerado o melhor aluno. Milton participou da cerimônia lendo o discurso que ele mesmo escreveu, mas não pôde participar do baile, que foi realizado em um clube que não permitia a entrada de negros ${ }^{275}$. Creio que esse tipo de experiência vivida por um membro do grupo é fundamental no que diz respeito às escolhas temáticas do mesmo.

Além de ser tema das letras, a cultura negra é importante como referência musical para o grupo. O jazz é uma delas e chega à produção analisada por influência principalmente de Toninho Horta, guitarrista muito ligado à bossa nova, que tem o jazz como elemento fundamental. "Talvez Dos Cruces seja uma visita ao Sketches of Spain, da dupla Miles Davis e Gil Evans ${ }^{276, ", ~ a f i r m a ~ o ~ c o m p o s i t o r ~ C h i c o ~}$ Amaral, mostrando a influência do gênero americano sobre o Clube da Esquina.

Nesse sentido, é importante entender também as especificidades do desenvolvimento da música negra em Minas Gerais, outra grande referência incorporada pelos músicos do Clube da Esquina. Rafael Senra Coelho explica que os povos negros que desembarcaram no Brasil vieram de diferentes regiões da África e fala sobre a distinção entre três ramos da cultura africana: a sudanesa (ioruba, nagô, jeje, fanti-ashanti), a guineano-sudanesa islamizada (fulahs, mandingas, haussás, tapas) e a banto (Angola, Congo e contra-Costa). Segundo o autor, a ala sudanesa ficou mais na Bahia e os bantos se espalharam para o Rio, Minas e outras regiões do Nordeste, o que explica, para ele, o parentesco entre xote e reggae e a influência caribenha na Bahia, enquanto o samba carioca sempre foi diferente do baiano.

\footnotetext{
${ }^{274}$ PAZ, Octavio. Os Filhos do Barro: do romantismo à vanguarda. Rio de Janeiro: Nova Fronteira, 1984, p. 195.

275 DUARTE, Maria Dolores Pires do Rio. Travessia: a vida de Milton Nascimento. Rio de Janeiro: Record, 2006, p. 66.

${ }^{276}$ BUENO, Andréa dos Reis Estanislau (org.). Coração americano: 35 anos do álbum Clube da Esquina. Belo Horizonte: Prax, 2008, p. 61.
} 
Ele afirma ainda que outra manifestação musical que se destacou em Minas Gerais entre os séculos XVIII e XIX foi a das bandas militares, que admitiam mulatos livres. Toninho Horta admite a influência dessas bandas em sua música quando trata da "estrutura da música só com sopros e percussão". Já o crítico J. Jota de Moraes mostra como a musicalidade de Milton Nascimento conseguiu reunir as tradições da música mineira do século XVIII e XIX.

Em outra dimensão - bem menos presa aos cânones da tradição da música escrita - sempre fizeram parte integrante do universo mineiro do canto dos escravos, os festejos, canções e danças sertanejas, bem como as atividades resultantes das serestas e serenatas. Elementos provenientes de todas essas fontes foram finalmente filtrados por Milton Nascimento, em um gesto só possível de ser concretizado por uma grande intuição como a sua. Não é a toa que em suas músicas aflorem, por vezes, intrincadas ondulações que lembram a antiga música sacra, gingados rítmicos da música negra e fios melódicos que derramam romanticamente, algo à maneira dos velhos exemplos seresteiros. (...) Entretanto, se Milton Nascimento fosse apenas voltado para o passado, não teria contribuído tanto para dar à música popular brasileira uma outra fisionomia ${ }^{277}$.

Ou seja, as influências melódicas africanas incorporadas pelo Clube da Esquina se aproximam de uma "África mineira, irmã dos congados, moçambiques e caiapós e tambus ${ }^{278, "}$

Além da análise de Moraes, que reconhece as referências existentes na música analisada sem deixar de citar sua dimensão inovadora, Coelho traz ainda outra informação importante para pensar a questão étnica no Clube da Esquina:

O mulatismo da música mineira deve ser também examinado. A quase inexistência de músicos brancos poderia ser explicada, em parte, pela própria posição sócio-econômica deles. O branco, mesmo sem título de bacharel, tinha sempre muitas opções profissionais. Mas no plano cultural, poderia-se esperar dele maior ação. (...) Trabalhando para entidades controladas pela elite branca, com a qual procuravam igualar-se, os mulatos buscaram aproximar-se sempre dos modelos europeus. Esta busca da cultura pela metrópole se explica também pelo desejo de afastar-se de suas origens negras, pelo pavor de olhar para

${ }^{277}$ MORAES, J. Jota de apud ${ }^{277}$ COELHO, Rafael Senra. Dois lados da mesma viagem: A Mineiridade e o Clube da Esquina. Dissertação de Mestrado. Promel - UFSJ: São João del-Rei, 2010, p. 39.

278 Ivan Vilela em texto de apresentação no Museu do Clube da Esquina: http://www.museuclubedaesquina.org.br/o-movimento/ 
trás, pela preocupação de cortar os laços com sua cultura própria. ${ }^{279}$.

Creio que não seja possível falar de corte de laços com a cultura negra na música do Clube da Esquina. O que tento mostrar nesse capítulo é justamente como esses laços estão presentes, assim como as referências a pelo menos outros dois grupos étnicos. No entanto, talvez seja sim possível pensar nessa aproximação do negro e do mulato com a cultura branca como tentativa de obter status em uma produção musical que serve de referência para os músicos do grupo. A "mulatice" na música do Clube da Esquina também foi apontada por Santuza Cambraia Naves, que afirma:

Milton cria uma persona híbrida, constituída de elementos africanos (oriundos principalmente do universo do jazz) e brancos (provenientes da experiência mineira, com sua família de adoção e sua religiosidade católica, e das informações contraculturais trazidas pelos Beatles). Preto retinto, ao dosar estes diferentes elementos, desenvolve uma mulatice cultural ${ }^{280}$.

Entendo, então, que muitas das misturas realizadas na música do Clube da Esquina provocam a convivência entre elementos negros e brancos, ou seja, temos aí mais uma das reuniões entre temas aparentemente opostos com as quais essa música opera.

Há também menção à "morena" como figura híbrida em Cravo e Canela, canção com percussão forte e ritmo dançante, com compasso ternário que vem do congado.

Morena quem temperou/ A cor de canela/ A lua morena/ A dança do vento/ O ventre da noite/ $\mathrm{E}$ o sol da manhã $\tilde{a}^{281}$

Mostrando a complexidade de se interpretar histórias híbridas, Canclini fala dos países latino-americanos afirmando que eles são "atualmente resultado da sedimentação, justaposição e entrecruzamento de tradições indígenas, do hispanismo colonial católico e das ações políticas educativas e comunicacionais

${ }^{279}$ COELHO, Rafael Senra. Dois lados da mesma viagem: A Mineiridade e o Clube da Esquina. Dissertação de Mestrado. Promel - UFSJ: São João del-Rei, 2010, p. 35.

${ }^{280}$ NAVES, Santuza Cambraia. Da Bossa Nova à Tropicália. Rio de Janeiro: Jorge Zahar Ed., 2004, p. 45.

${ }^{281}$ Trecho da canção Cravo e Canela, de Milton Nascimento e Ronaldo Bastos, álbum Clube da Esquina, 1972. 
modernas $282 \%$. Vejo essa complexidade tanto nas letras quanto nas melodias citadas, através da utilização de instrumentos e ritmos tribais, hispânicos e africanos.

A canção de Pablo Milanes e Chico Buarque de Hollanda cantada pelo último e por Milton no álbum Clube da Esquina 2 conta uma história muito importante para entendermos como esses músicos veem a relação entre os povos da América Latina, que são colocados como "irmãos" que foram separados e se tornam estranhos, mas termina apontando para uma possibilidade de reinventar essa trama:

El nascimiento de un mundo/ Se aplazó por un momento/ Fue un breve lapso del tempo/ Del universo un segundo/ Sin embargo parecia/ Que todo se iba a acabar/ Con la distancia mortal/ Que separó nuestras vidas/ Realizavan la labor/ De desunir nossas mãos/ E fazer com que os irmãos/ Se mirassem com temor/ Cunado passaron los años/ Se acumularam rancores/ Se olvidaram os amores/ Parecíamos estraños (...) Lo que brilla con luz propia/ Nadie lo puede apagar/ Su brillo puede alcanzar/ La oscuridad de otras costas/ Quem vai impedir que a chama/ Saia iluminando o cenário/ Saia incendiando o plenário/ Saia inventando outra trama ${ }^{283}$

Quanto à valorização da América Latina, esse era um sentimento comum à época. A existência de canções como Soy Loco por Ti America, de Gilberto Gil e Capinam, gravada por Caetano Veloso (álbum Caetano Veloso, 1967), é um exemplo de como esse era um tema importante para a música brasileira. Ressalto aqui que a forma como o Clube da Esquina trabalha suas referência musicais latinas é muito diferente da forma como a tropicália ou mesmo Gil e Caetano em suas carreiras o fazem, aparecendo principalmente na obra de Caetano uma apropriação do kitsch, daquilo que é historicamente desvalorizado pela crítica musical dentro do universo latino-americano. No entanto, a existência dessas diferenças não é contrária à afirmação de que há nesse momento na música brasileira um olhar voltado para a valorização da América Latina e suas tradições culturais.

Para Heloísa Starling,

${ }^{282}$ CANCLINI, Néstor Garcia. Culturas Híbridas. São Paulo: Edusp, 1998, p. 73.

${ }^{283}$ Trecho da canção Cancion por la unidad de Latino America, de Pablo Milanes e Chico Buarque de Hollanda, Clube da Esquina 2, 1978. 
À essa mistura os mineiros acrescentaram alguns outros ingredientes importantes: uma desconcertante fusão brasileira com o jazz que remetia, em última instância, a fusion inaugurada por Miles Davis, a incorporação das conquistas musicais da bossa nova, além do acréscimo de uma dose farta e própria de iberismo - um iberismo na verdade muito distinto do viés carnavalizado e parodístico proposto pela Tropicália, interessada sobretudo em apresentar o sentido de fantasia feérica da fundação política brasileira, ao mesmo tempo carnaval e manto de Artur Bispo do Rosário, com sua colagem de fragmentos, ornatos, idéias deslocadas, parangolés. Assim, diferente da Tropicália, a versão ibérica do Clube da Esquina postula nova ênfase e recupera nas canções outros traços particulares às modalidades de vida próprias à América ibérica $^{284}$.

Tomar a América Latina como tema também está relacionado com o surgimento da Nueva Canción, movimento latino-americano iniciado com a nueva trova na Cuba revolucionária na década de 1960, que logo chega ao Chile e à Argentina, onde os músicos cantavam sobre a injustiça e a opressão em seus países. No Chile, o movimento contou com a participação de artistas como Victor Jara e Violeta Parra, e na Argentina, com Atahualpa Yupanqui e Mercedes Sosa, que misturavam antigas tradições andinas musicais com letras socialmente conscientes. É significativo que Sosa tenha se apresentado diversas vezes com Milton Nascimento e outros músicos do Clube da Esquina, que também gravaram uma música de Violeta Parra, como citado anteriormente. Além de refletir a solidariedade entre os latino-americanos, a Nueva Canción ecoou o sentimento antiamericano resultante da Guerra do Vietnã e se tornou uma plataforma adequada para expressar pontos de vista anti-imperialistas ${ }^{285}$.

Algumas letras dos discos analisados mostram a visão dos autores do modo como sua região se articula com o mundo, além de uma crítica à posição de esquecimento e marginalização da América Latina em relação à ideia de Europa e Estados Unidos como "globo".

Realizavam la labor/ De desunir nossas mãos/ E fazer com que os irmãos/ Se mirassem con temor/ Cuando passaram los años/

${ }^{284}$ STARLING, H. Coração americano; panfletos e canções do Clube da Esquina. In: MOTTA, R. (ORG.). O golpe e a ditadura militar 40 anos depois (1964-2004). São Paulo: Edusc, 2004, p. 6.

285

MAULEON,

Rebeca.

Disponível

em:

http://worldmusic.nationalgeographic.com/view/page.basic/genre/content.genre/nueva_cancion_76 $\underline{\text { 2/en_US. }}$. 
Se acumularam rancores/ Se olvidaram os amores/ Pareciamos extraños/ Que distância tão sofrida/ Que mundo tão separado/ Jamás se hubiera encontrado/ Sin aportar nuevas vidas ${ }^{286}$

Por que vocês não sabem do lixo ocidental?/ Não precisam mais temer/ Não precisam da solidão/ Todo dia é dia de viver/ Por que você não verá meu lado ocidental?/ Não precisa medo não/ Não precisa da timidez/ Todo dia é dia de viver/ Eu sou da América do Sul/ Eu sei, vocês não vão saber ${ }^{287}$

Para Paul Gilroy,

Com algumas nobres exceções, as explicações críticas da dinâmica da subordinação e da resistência negra têm sido obstinadamente monoculturais, nacionais e etnocêntricas. Isso empobrece a história cultural negra moderna, pois as estruturas transnacionais que trouxeram à existência o mundo do Atlântico negro também se desenvolveram e agora articulam suas múltiplas formas em um sistema de comunicações globais constituído por fluxos ${ }^{288}$.

Acredito que o Clube da Esquina pode ser uma das exceções de que fala o autor, pois tanto a questão negra quanto outras locais, étnicas ou de grupos minoritários estão articuladas com questões globais. O tema da identidade negra é forte na música analisada, mas esta não é marcada especificamente como produto negro ou da escravidão, como a produção estudada por Gilroy. Os índios, os latinos, os brasileiros, os mineiros e muitos outros povos são assunto e referência deste que também é um grupo, de músicos e amigos que escolhem determinados temas para transformar em música.

\footnotetext{
${ }^{286}$ Trecho da canção Cancion por La Unidad de Latino America, de Chico Buarque de Hollanda e Pablo Milanes, álbum Clube da Esquina 2, 1978.

${ }^{287}$ Trecho da canção Para Lennon a McCartney, de Lô Borges, Márcio Borges e Fernando Brant, álbum Milton, 1970.

${ }^{288}$ GILROY, Paul. O Atlântico Negro. Modernidade e dupla consciência. São Paulo, Rio de Janeiro: Editora 34/Universidade Cândido Mendes, 2001, p. 170.
} 


\section{4. "E o que foi feito é preciso conhecer para melhor prosseguir": Uma produção musical pela via da amizade}

Um grupo de jovens se encontrou em meados dos anos 1960 na cidade de Belo Horizonte e começou a criar músicas. "Eram jovens com afinidades eletivas que se juntam por uma 'via magnética' chamada Milton Nascimento ${ }^{289}$ ". Partindo dessas afinidades e da trajetória musical então já iniciada de Milton, fizeram de muitos temas canção, reuniram referências variadas.

Herdaram dos músicos modernistas brasileiros a valorização da tradição e a fusão de temas regionais e urbanos. Em seu trabalho sobre o grupo do Modernismo dos anos 1920, Santuza Cambraia Naves chama atenção para um modo de atuar no campo da música popular, em que muitas vezes se promovem inovações recorrendo à tradição. Para a autora, existe uma "convivência de fantasias de modernização com outras associadas a um registro antigo. A roça se confunde com a cidade e o mundo objetivo recebe um tratamento subjetivo ${ }^{290}$ ". Como vimos no primeiro capítulo, a música do Clube da Esquina opera desta mesma forma, privilegiando tanto nos temas regionais quanto nos urbanos algumas referências mineiras, valorizando a tradição local.

Da bossa nova, vieram a sofisticação melódica e instrumental e as influências do jazz. Muitos dos músicos do Clube da Esquina falam do movimento carioca como um momento em que despertaram a atenção para a música brasileira e as inovações que era possível fazer a partir dela e reconhecem suas influências como fundamentais em sua formação musical.

Do tropicalismo vem a possibilidade de olhar para a música estrangeira, incorporar a música pop, a guitarra e o rock sem que isso se torne uma questão a ser discutida na esfera cultural. Creio que a aceitação pela crítica e pelo público da música do Clube da Esquina combinada a sua postura não midiática só é possível porque é uma produção que surgiu após o movimento tropicalista, que alguns

\footnotetext{
${ }^{289}$ Ronaldo Bastos em depoimento concedido a esta pesquisa.

${ }^{290}$ NAVES, Santuza Cambraia. O violão azul: modernismo e música popular. Rio de Janeiro: Editora Fundação Getúlio Vargas, 1998, p. 17.
} 
anos antes assumiu uma postura antropofágica dentro da música brasileira. Não fosse isso, o Clube da Esquina talvez não tivesse obtido tal alcance, o reconhecimento nacional e internacional, sua inclusão no universo da chamada MPB, então valorizada estética e comercialmente.

Mas a música do Clube da Esquina não deve nem pode ser explicada pela reunião apenas desses elementos. Os temas são ainda mais numerosos. São tantas influências quanto são os que participam dessa formação.

Com Milton Nascimento vem a inovação na forma de compor, as harmonias inusitadas, o toque diferente do violão, as informações do catolicismo mineiro e do interior de Minas Gerais, além da articulação com a música e músicos latinoamericanos. Ivan Vilela explica algumas novidades trazidas por Milton no campo musical:

Milton inaugura uma nova forma de utilização do violão: como um instrumento ao mesmo tempo harmônico e percussivo. No samba e na bossa nova temos um violão batido dentro de um esquema rítmico. Na Tropicália e Jovem Guarda, a utilização do instrumento é feita de forma rasgueada (ou rasgada ou rasqueada é tocar violão passando os dedos ou a palheta pelas cordas correndo, de cima para baixo ou vice-versa, fazendo as cordas soarem; é uma forma não dedilhada de tocar violão), porém ainda respeitando um sistema rítmico predominante. Em Milton, poderíamos dizer que o violão passa a ser um instrumento arrítmico e de cordas percussivas. (...) Toda a base da música brasileira foi construída dentro de padrões rítmicos binários, ternários e quaternários. Milton desenvolve músicas em compassos quinários (em cinco tempos), além de trabalhar com compassos híbridos (pulsações diferentes numa mesma música). E também a execução de um samba, originalmente binário, em ritmo ternário ${ }^{291}$.

Lô Borges trouxe a guitarra com grande inspiração na música pop, nos Beatles e no rock progressivo. Chico Amaral ressalta que apesar da inspiração declarada, nenhuma das músicas de Lô se parecia com a do quarteto inglês, e observa uma ligação das composições do jovem mineiro com a música erudita.

A balada Trem Azul, bem como as demais composições de Lô (do álbum Clube da Esquina de 1972), mostram, com clareza, que havia mais do que a influência dos Beatles em seu trabalho. Ele havia alcançado, antes dos vinte anos, o patamar dos

291 VILELA, Ivan. Texto de apresentação do Museu do Clube da Esquina. http://www.museuclubedaesquina.org.br/o-movimento/. 
grandes compositores. Suas músicas (nenhuma se parecendo com a dos Beatles) traziam novidade melódica e harmônica, dentro de uma forma impecável. (...) Trem Azul tem uma certa atmosfera do Pink Floyd, mas sua construção é inédita. Poderia estar em Eric Satie ou Debussy ${ }^{292}$ !

E com Lô vem Beto Guedes, que além das informações do rock traz influências da música regional de Montes Claros, cidade onde nasceu, e do pai, Godofredo, que era músico e fazia em casa rodas de choro e samba.

Sobre a aproximação com a música erudita, uma das figuras principais para que houvesse essa correspondência foi Wagner Tiso. A mãe de Wagner era professora de piano e ele tomou aulas desde muito pequeno, além de tocar acordeon. Ele conta sobre a influência em sua formação da música clássica e da música religiosa que se ouvia em Três Pontas, cidade onde nasceu e conheceu Milton:

As procissões religiosas em Três Pontas tiveram muita influência na minha formação musical. Outra influência era o impacto da música que a gente via no cinema, quando menino. A gente via os seriados de cinema e eles usavam muita música clássica, usavam muito Wagner. $\mathrm{E}$ aquela música, aquele movimento de orquestra, aquilo me encantava muito. (...) Então foi um primeiro impacto na minha formação musical. A música sacra teve uma influência muito grande também; eu lembro inclusive que às 6 horas da tarde a gente ficava triste porque escurecia; ficava aquela música na igreja, os sinos batendo. Mas aquilo entrou na gente. (...) Eu estudei em colégio de padre, porque formação de músico ali era importante. Músico, que eu digo, eram os corais. Tinha que ter corais, tinha aula de música. Então é realmente muito importante essa formação litúrgica, formação sacra; acho que foi importante não só pra mim, mas pra todo mundo. Acho que usei mais porque eu saía pro mundo pra trabalhar e usei muita orquestra, então isso está sempre mostrando as minhas influências. Eu tenho essa oportunidade de mostrar as influências que eu tive ${ }^{293}$.

Toninho Horta, como já vimos, tem uma formação musical ligada ao jazz e à bossa nova, assim como Paulo Moura, músico responsável pela regência em várias canções do Clube da Esquina.

Entre os letristas, Fernando Brant é um grande cronista das Minas Gerais e um dos que traz os temas religiosos. Já Márcio Borges traz uma poética inovadora,

\footnotetext{
${ }^{292}$ BUENO, Andréa dos Reis Estanislau (org.). Coração americano: 35 anos do álbum Clube da Esquina. Belo Horizonte: Prax, 2008, p. 61.

${ }^{293}$ Wagner Tiso em depoimento ao Museu do Clube da Esquina.
} 
que tem a juventude como tema e assuntos conectados com a sensibilidade contracultural, que encontra em Ronaldo Bastos seu maior representante. Nas letras de Ronaldo, sempre muito sensoriais, estão algumas das paisagens que a música do Clube da Esquina imortalizou.

A lista de participantes é muito maior, assim como a de influências trazidas por eles que se tornaram tema dessa música, mas temos aí a origem de algumas referências que estudei neste trabalho.

Milton aparece como figura fundamental para pensar essa formação, porque é apontado como núcleo, indicando não apenas quem entra no grupo, mas também fazendo certas escolhas. Tudo passa, com maior ou menor força, por ele. Segundo Andréa Bueno,

"Mito Nascimento", como diz Nivaldo Duarte, técnico de gravação da EMI, aparece em todos os depoimentos como a figura central, o aglutinador, aquele que possibilitou o despontar musical de várias gerações, a fusão de varias influências musicais, de vários talentos que resultaram em trabalhos muito importantes para a música popular brasileira ${ }^{294}$.

Essa ideia de Milton como figura central ficou clara nas entrevistas que fiz, em que várias respostas sobre as escolhas estéticas nas músicas passavam por ele, desde decisões mais simples, como qual de suas músicas Danilo Caymmi gravaria no disco, até a ideia de que Lô Borges assinaria com ele o disco do grupo.

Bernardo Novais da Mata Machado lança mão da imagem de uma onda de sucessivos círculos concêntricos, formada por uma pedra atirada em um lago, para explicar o papel de cada músico no Clube da Esquina:

Ao centro, Milton Nascimento, a pedra primordial; no primeiro círculo, Wagner Tiso, Fernando Brant, Ronaldo Bastos e os irmãos Borges: Márcio, Marilton, Telo e Lô; no segundo círculo os músicos e compositores Beto Guedes, Toninho Horta, Tavinho Moura, Flávio Venturini, Nelson Ângelo e o letrista Murilo Antunes; no círculo seguinte, músicos como Nivaldo Ornellas, Paulinho Carvalho e os integrantes do Som Imaginário: Fredera, Luíz Alves, Tavito, Robertinho Silva e Zé Rodrix; em seguida, compositores e músicos que conviveram e foram influenciados pelo Clube, e que depois seguiram

\footnotetext{
${ }^{294}$ BUENO, Andréa dos Reis Estanislau (org.). Coração americano: 35 anos do álbum Clube da Esquina. Belo Horizonte: Prax, 2008, p. 17.
} 
carreiras-solo, entre eles: Sirlan, Celso Adolfo, Tadeu Franco, Juarez Moreira e Marina Machado ${ }^{295}$.

Por achar complicado fazer essa análise medindo o nível de influência ou importância de cada um, pensando em ondas maiores ou menores para grupos separados, prefiro pensar o Clube da Esquina partindo da "neomonadologia" desenvolvida por Gabriel Tarde. O autor retoma a ideia das mônadas, originalmente formulada por Leibniz no campo da filosofia, que significa a substância simples e única, para demonstrar como as descobertas da ciência cada vez mais levam à conclusão de que "o infinitesimal se torna a chave do universo inteiro $^{296 "}$.

Em um sistema monadológico ou atomístico qualquer, todo fenômeno não é senão uma nebulosa decomponível em ações emanadas de uma infinidade de agentes que são outros tantos pequenos deuses invisíveis e inumeráveis ${ }^{297}$.(...) Mas é preciso chegar ao mundo social para ver as mônadas apreenderem-se de maneira nua e sensível pela infinidade de seus caracteres transitórios plenamente desdobrados um diante do outro, um no outro, um pelo outro. Essa é a relação por excelência, a possessão típica da qual o restante é senão um esboço ou um reflexo. Pela persuasão, pelo amor e pelo ódio, pelo prestígio pessoal, pela comunhão das crenças e das vontades, pela cadeia mútua do contrato, espécie de rede cerrada que não cessa de entender-se, os elementos sociais se ligam e se esticam de mil maneiras, e de sua cooperação nascem as maravilhas da civilização ${ }^{298}$.

Não é novidade pensar os fatos sociais construídos peça por peça, cada uma delas tendo nomes diversos para o que aqui chamamos de mônadas, uma transformando a outra e se modificando através da outra. O tempo e o espaço são exemplos de fatores considerados nessas relações. Mas além de todos esses fatores, quero aqui pensar cada integrante do Clube da Esquina como uma mônada que traz para a produção musical suas experiências diversas, ressignificadas quando compartilhadas com o grupo e postas em música.

\footnotetext{
${ }^{295}$ BUENO, Andréa dos Reis Estanislau (org.). Coração americano: 35 anos do álbum Clube da Esquina. Belo Horizonte: Prax, 2008, p. 105.

${ }^{296}$ TARDE, Gabriel. Monadologia e sociologia - e outros ensaios. São Paulo: Cosac Naify, 2007, p. 58.

${ }^{297}$ Idem, p. 78.

${ }^{298}$ Idem, p. 118.
} 
E para usar os termos do autor, devo analisar o que constitui essa relação no Clube da Esquina, o que liga esses elementos sociais. Acredito que a resposta seja a amizade.

Como é possível que um grupo tão diverso produza dois álbuns, além de outros trabalhos não analisados aqui, cuja coesão é forte a ponto de colocar tudo sob um mesmo nome, chegando a ser definido como movimento por alguns autores? Como tantas e tão diversas referências puderam fazer parte de um mesmo projeto? E como é possível, dentro dessa produção, encontrar temas recorrentes e elencálos, como tentei fazer neste trabalho, revelando certas afinidades entre os diversos indivíduos do grupo? Além de fatores como as referências geracionais, o contexto histórico e a vivência no espaço urbano, no caso do Clube da Esquina, tendo a acreditar que essa reunião tornou-se possível pelo que denomina-se "amizade".

A postura de Claudia Barcellos Rezende ao desnaturalizar a ideia de amizade me pareceu acertada e importante como forma de pensar o conceito neste trabalho. A autora mostra como esse tipo de relação pode revelar uma função social ao tornarse parte do processo de construção de identidades e alteridades.

A meu ver, os discursos sobre a amizade revelam uma série de aspectos mais gerais acerca da dinâmica social de cada um dos contextos socioculturais estudados. São, pois, discursos implícitos sobre o processo de fazer distinções sociais, refletindo questões muitas vezes ambíguas na forma de construir identidades e alteridades ${ }^{299}$.

O fato de o grupo estudado ser um conjunto de amigos revela a existência de uma dinâmica em que cada indivíduo leva algumas de suas características e ideias para dentro do convívio do grupo, o que, no caso de produtores de música, acaba por construir também a identidade daquela produção musical.

Para Bruno Viveiros Martins, a música do Clube da Esquina mostra a amizade como forma de promover e fortalecer os laços sociais, o que

constitui uma alternativa frente à ruptura da sociabilidade urbana, à despolitização e ao esvaziamento da esfera pública. A amizade que vem à tona entre versos e acordes musicais representa, portanto, uma nova chance para a recuperação do

\footnotetext{
${ }^{299}$ REZENDE, Claudia Barcellos. Os significados da amizade: duas visões de pessoa e sociedade. Rio de Janeiro : Editora FGV, 2002, p. 16.
} 
valor da política dentro de uma comunidade, principalmente, em um período histórico marcado pelo declínio da liberdade, enquanto exercício da ação política ${ }^{300}$.

Os participantes do grupo, antes de músicos, são amigos. Alguns inclusive só se tornaram músicos por fazerem parte dessa rede de amizades, tema recorrente nas letras das músicas ${ }^{301}$.

Que notícias me dão dos amigos? $?^{302}$

O que foi feito amigo/ De tudo que a gente sonhou? $?^{303}$

Caminho por uma rua/ Que passa em muitos países/ Se não me vêem, eu vejo/ E saúdo velhos amigos ${ }^{304}$

Que bom, amigo/ Poder saber outra vez que estás comigo ${ }^{305}$

Os trechos mostram a importância do tema para o grupo, mas quando falo da amizade me refiro não apenas a ela como tema das canções, mas como causa e também consequência das "afinidades eletivas", de que fala Ronaldo Bastos, entre esses integrantes, como fator que faz a ligação entre os músicos e permite que tantas individualidades estejam representadas na música do grupo.

Nesse caso, retomo a ideia de Viveiros Martins sobre o modo como a amizade, no Clube da Esquina, toma um significado diferente do que tem na modernidade, em que é pensada e vivida como uma experiência íntima, privada ${ }^{306}$.

Quando o autor afirma que na música do grupo são resgatados "traços característicos dos grandes discursos sobre a amizade que perpassam o tempo e

${ }^{300}$ MARTINS, Bruno Viveiros. Som Imaginário: a reinvenção das cidades nas canções do Clube da Esquina. Belo Horizonte: Editora UFMG, 2009, p.83.

${ }^{301}$ Embora não faça parte dos discos analisados, é importante citar a canção Canção da América, de Milton Nascimento e Fernando Brant, lançada em 1980 no disco Sentinela e até hoje reconhecida como um hino à amizade.

302 Trecho da canção Nada será como antes, de Milton Nascimento e Ronaldo Bastos, álbum Clube da Esquina, 1972.

${ }^{303}$ Trecho da canção O Que Foi Feito Devera, de Milton Nascimento e Fernando Brant, álbum Clube da Esquina 2, 1978.

${ }^{304}$ Trecho da canção Canção Amiga, de Milton Nascimento e Carlos Drummond de Andrade, álbum Clube da Esquina 2, 1978.

${ }^{305}$ Trecho da canção Que Bom Amigo, de Milton Nascimento, álbum Clube da Esquina 2, 1978.

${ }^{306}$ MARTINS, Bruno Viveiros. Som Imaginário: a reinvenção das cidades nas canções do Clube da Esquina. Belo Horizonte: Editora UFMG, 2009, p.85. 
chegam até nós", acredito que essa ideia também possa explicar a convivência harmônica dos temas que se fazem presentes nessa produção musical, a criação dessas canções.

Para Montaigne, é a correspondência dos gostos que engendra as verdadeiras e perfeitas amizades ${ }^{307}$. Não à toa muitas vezes a explicação dos músicos entrevistados sobre suas escolhas passava pela ideia de gosto, ou seja, gostar de determinado tema fazia com que este fosse incorporado. Isso quer dizer que a amizade não é apenas assunto do Clube da Esquina, ela é também um elo entre os indivíduos e, consequentemente, entre os assuntos.

Vejamos os depoimentos de Márcio Borges e Wagner Tiso:

aqui estão expostas nossas vidas de compositores, poetas, cantores e seres humanos. Pois nossas diferenças de sempre e as diferenças acirradas pelo tempo e as diferenças de agora, não abolirão o fato de que somos frutos das mesmas circunstâncias, amigos ou ex-amigos quase de infância, artífices da mesma história, parceiros de tantas obras-primas. E mesmo que nossa amizade tantas vezes só se mostre como flash em memórias cada dia mais falhas, ainda somos ecos do mesmo grito, personagens da mesma lenda, co-autores da mesma revolução harmônica e poética, mesmo que a gente se esqueça, "como uma pêra se esquece dormindo numa fruteira" ${ }^{308}$.

O Clube da Esquina foi um sopro de juventude na música brasileira! Éramos todos sonhadores e originais. Tínhamos a música como um elo importante de amizade, companheirismo e esperança de um futuro brilhante para todos. Cultivo até hoje bons amigos, alguns daqueles primeiros momentos e outros que o tempo se encarregou de aproximar ${ }^{309}$.

Para Luiz Henrique Assis Garcia, existe uma relação consubstancial que opera entre as escolhas estéticas e as escolhas ideológicas e uma relação estrutural entre os valores e as formas de sociabilidade ${ }^{310}$.

\footnotetext{
${ }^{307}$ MONTAIGNE, Da Amizade. In: Ensaios - I, p. 96.

${ }^{308}$ Márcio Borges em BUENO, Andréa dos Reis Estanislau (org.). Coração americano: 35 anos do álbum Clube da Esquina. Belo Horizonte: Prax, 2008, p. 21.
}

${ }^{309}$ Wagner Tiso, Idem, p. 96.

${ }^{310}$ GARCIA, Luiz Henrique Assis. Coisas que ficaram muito tempo por dizer: O Clube da Esquina como formação cultural. Dissertação apresentada ao Curso de Mestrado do Programa de Pós- Graduação do Departamento de História da Faculdade Filosofia e Ciências Humanas da Universidade Federal de Minas Gerais, 2000. 
Não é o caso de discutir até que ponto os músicos de que tratamos seriam "intelectuais", mas sim de aproveitar para o campo artístico a importante constatação de TREBITSH: os produtores culturais podem se associar por laços de amizade, por idéias e vivências comuns à sua geração e pela possibilidade de implementar conjuntamente projetos de cunho pessoal.

Como afirma Tiso, a música é um elo de amizade, mas acredito que a relação inversa também seja verdadeira e ajude a entender as escolhas musicais do Clube da Esquina. E a própria história contada por Márcio no livro Os Sonhos não Envelhecem faz perceber como aquele grupo de pessoas, liderado por Milton, vai incorporando novos parceiros e com eles novas ideias, criando uma nova música. 


\section{Posfácio: Embaralhando / Desconstruindo Classificações $^{311}$}

A ideia deste trabalho nunca foi desvendar as escolhas musicais do Clube da Esquina, mas apontar algumas delas que me pareceram mais recorrentes e pensar como elas aparecem nessa produção musical. Entre os muitos temas com os quais a música do grupo trabalha, optei por deixar de lado alguns, como o amor romântico e a infância, devido a fatores como tempo e espaço, curtos no caso da elaboração de uma dissertação de mestrado.

Entre aqueles que abordei, é possível concluir que existe no Clube da Esquina um repertório ligado à mineiridade, assim a como temas universais, sem poder descartar também a brasilidade, fraca, mas existente. Posso dizer também que encontrei temas políticos sem serem programáticos, contraculturais em uma música que acaba se tornando parte do status quo. É uma música popular com referências eruditas, é negra, latina, indígena, branca, mulata. É inclassificável.

E não era mesmo para classificar. Talvez a única conclusão possível seja dizer que é preciso ouvir o Clube da Esquina. E ouvir, neste trabalho, foi fundamental. Busquei aqui tomar a música como discurso principal, procurando nela tanto as perguntas quanto as tentativas de respostas. Se tive, confesso, uma preocupação ao ouvir de Tavinho Moura que não tentasse entender o "balaio de gato" para que não "perdesse a graça", esse trabalho mostra, pelo menos para mim, que há "força", "raça", "graça" e "sonho sempre ${ }^{312, ", ~ e m ~ c a d a ~ n o t a . ~}$

\footnotetext{
${ }^{311}$ Como homenagem, utilizo aqui o título dado por Santuza Cambraia Naves a um dos subitens do capítulo de conclusão de $O$ violão azul: modernismo e música popular, "Embaralhando classificações".

${ }^{312}$ Expressões retiradas da canção Maria Maria, de Milton Nascimento e Fernando Brant, álbum Clube da Esquina 2, 1978.
} 


\section{Referências Bibliográficas}

ALMEIDA, Maria Isabel Mendes de e NAVES, Santuza Cambraia (orgs.). "Por que não?': rupturas e continuidades da contracultura. Rio de Janeiro: 7Letras, 2011.

AVELAR, Idelber. De Milton ao Metal: Política e Música em Minas. Disponível

em: http://www.hist.puc.cl/iaspm/rio/Anais2004\%20\%28PDF\%29/IdelberAvelar.pdf.

BAHIANA, Ana Maria. Nada será como antes - MPB nos anos 70. Rio de Janeiro: Civilização Brasileira, 1980.

BARBOZA FILHO, Rubem. Tradição e Artifício - Iberismo e Barroco na Formação Americana. Belo Horizonte: Ed. UFMG; Rio de Janeiro: IUPERJ, 2000 .

BASUALDO, Carlos (org.). Tropicália - Uma revolução na cultura brasileira. São Paulo: Cosac Naify, 2007.

BHABHA, Homi K. O local da cultura. Belo Horizonte: Ed. UFMG, 1998.

BOMENY, Helena (Org.). Constelação Capanema: intelectuais e política. Rio de Janeiro: Ed. Fundação Getulio Vargas; Bragança Paulista(SP): Ed. Universidade de São Francisco, 2001.

Guardiães da razão: modernistas mineiros. Rio de Janeiro: Editora UFRJ/ Tempo Brasileiro, 1994.

BORGES, Márcio. Os sonhos não envelhecem: Histórias do Clube da Esquina. São Paulo: Geração Editorial, 2009.

BRANT, Fernando. Fernando Brant em depoimento a Liana Fortes. Rio de Janeiro: Ed. Rio (Coleção Gente), 2005.

BUENO, Andréa dos Reis Estanislau (org.). Coração americano: 35 anos do álbum Clube da Esquina. Belo Horizonte: Prax, 2008.

CAMPOS, Haroldo de. O Sequestro do Barroco na Formação da Literatura Brasileira: O Caso Gregório de Mattos. São Paulo: Ilumiuras, 2011.

CANCLINI, Néstor García. A Globalização Imaginada. São Paulo: Iluminuras, 2007.

Culturas Híbridas. São Paulo: Edusp, 1998.

Diferentes, desiguais e desconectados: mapas da

interculturalidade. Rio de Janeiro: Editora UFRJ, 2009.

CARVAlHO, José Murilo. Cidadania no Brasil: o longo caminho. Rio de Janeiro: Civilização Brasileira, 2006. 
CERQUEIRA, Hugo E. A. da Gama e SIMÕES, Rodrigo. Modernização e diferenciação econômica em Belo Horizonte. In: Varia História. Belo Horizonte, n.18, novembro de 1997.

COELHO, Rafael Senra. Dois lados da mesma viagem: A Mineiridade e o Clube da Esquina. Dissertação de Mestrado. Promel - UFSJ: São João del-Rei, 2010.

DUARTE, Maria Dolores Pires do Rio. Travessia: a vida de Milton Nascimento. Rio de Janeiro: Record, 2006.

DUARTE, Paulo Sérgio e NAVES, Santuza Cambraia (orgs.). Do SambaCanção à Tropicália. Rio de Janeiro: Relume Dumará: FAPERJ, 2003.

FELD, Steven. Uma doce cantiga de ninar para a 'world music'. In: Debates Cadernos do programa de Pós-Graduação em Música. Rio de Janeiro: Centro de Letras e Artes Unirio, nº 8 , dezembro de 2005.

FICO, Carlos e ARAUJO, Maria Paula (org.). 1968: 40 anos depois. Rio de Janeiro, 7 Letras, 2009.

GARCIA, Luiz Henrique Assis. Coisas que ficaram muito tempo por dizer: $O$ Clube da Esquina como formação cultural. Dissertação de Mestrado FAFICH- UFMG: Belo Horizonte, 2000.

GELDER, Ken e THORNTON, Sarah (org.). The Subcultures Reader. London and New York: Routledge, 1997.

GILROY, Paul. O Atlântico Negro. Modernidade e dupla consciência. São Paulo, Rio de Janeiro: Editora 34/Universidade Cândido Mendes, 2001.

GIUMBELLI, Emerson, DINIZ, Júlio Cesar Valladão e NAVES, Santuza Cambraia (orgs.). Leituras sobre música popular: reflexões sobre sonoridades e cultura. Rio de Janeiro: 7Letras, 2008.

HALL, Stuart. A identidade cultural na pós-modernidade. Rio de Janeiro: DP\&A, 2002.

IANNI, Octavio. Pensamento Social no Brasil. Bauru, SP: EDUSC, 2004.

LEMOS, Celina Borges. Determinação do espaço urbano: a evolução econômica, urbanística e simbólica do centro de Belo Horizonte. Dissertação de Mestrado. FAFICH - UFMG, 1988.

MARCUS, George E. e MYERS, Fred R. (org.). The traffic in culture: refiguring art and anthropology. University of California Press. Berkeley and Los Angeles, Califórnia, 1995.

MARTINS, Bruno Viveiros. Som Imaginário: a reinvenção das cidades nas canções do Clube da Esquina. Belo Horizonte: Editora UFMG, 2009.

MONTAIGNE, Da Amizade. In: Ensaios - I.

MONTE-MÓR, Roberto Luís M., Belo Horizonte, Capital de Minas, século XXI. In: Varia História. Belo Horizonte, n.18, novembro de 1997. 
MOTTA, Rodrigo Patto Sá; RIDENTI, Marcelo; e REIS FILHO, Daniel Araão. (ORG.). $O$ golpe e a ditadura militar 40 anos depois (1964-2004). São Paulo: Edusc, 2004.

MUSEU CLUBE DA ESQUINA. Guia turístico de Belo Horizonte: roteiro Clube da Esquina/ Museu Clube da Esquina - Belo Horizonte, 2011.

NAVES, Santuza Cambraia. Canção popular no Brasil: a canção crítica. Rio de Janeiro: Civilização Brasileira, 2010.

Jorge Zahar Ed., 2004.

Da Bossa Nova à Tropicália. Rio de Janeiro:

O violão azul: modernismo e música popular.

Rio de Janeiro: Editora Fundação Getúlio Vargas, 1998.

NAPOLITANO, Marcos. O conceito de “MPB" nos anos 60. In: História: Questões e Debates. Curitiba: Editora da UFPR, n. 31, p 11-30, 1999.

OLIVEN, Ruben George. A parte e o todo: A Diversidade Cultural no BrasilNação. Petrópolis: Vozes, 1992.

PAZ, Octavio. Os Filhos do Barro: do romantismo à vanguarda. Rio de Janeiro: Nova Fronteira, 1984.

PEREIRA, Carlos Alberto Messeder e HOLLANDA, Heloísa Buarque de. Patrulhas Ideológicas - Marca Reg.: arte e engajamento em debate. São Paulo: Brasiliense.

PEREIRA, Carlos Alberto Messeder. Retrato de época: poesia marginal anos 70. Rio de Janeiro, FUNARTE, 1981.

PEIXOTO, Fernanda Arêas. Diálogos Brasileiros: Uma análise da Obra de Roger Bastide. São Paulo: Editora da Universidade de São Paulo, 2000.

PINTO, Tiago de Oliveira. Som e música. Questões de uma Antropologia Sonora. Revista de Antropologia, vol.44, nº.1. São Paulo: 2001.

POGGIOLI, Renato. The Theory of the avant-garde. Massachussets: The Belknap Press of Harvard University Press Cambridge, 1981.

RAMOS, Miguel Jost. $\operatorname{Re}($ Des)organizando o movimento: Um Olhar sobre a música popular brasileira na década de 70. Dissertação de Mestrado. Rio de Janeiro: PUC-Rio, Abril de 2007.

REZENDE, Claudia Barcellos. Os significados da amizade: duas visões de pessoa e sociedade. Rio de Janeiro : Editora FGV, 2002.

RIBEIRO, Gustavo Lins. Diversidade Cultural enquanto Discurso Global. In: Revista Desigualdade e Diversidade, Revista do departamento de Sociologia e Política da PUC-Rio. Rio de Janeiro, 2008.

RIVERA, Angel G. Quintero. Salsa, identidad y globalización. Redefiniciones caribeñas a las geografías y el tempo. TRANS - Revista Transcultural de Música, Trans 6 (2002). 
SANDRONI, Carlos. O mangue e o mundo: notas sobre a globalização musical em Pernambuco. Claves, CCHLA - UFPB. Dispon[ivel em: http://www.ccta.ufpb.br/claves/pdf/claves07/claves 7 o mangue e o mundo.pdf

SOVIK, Liv. Aqui ninguém é branco. Rio de Janeiro: Aeroplano, 2009.

TARDE, Gabriel. Monadologia e sociologia - e outros ensaios. São Paulo: Cosac Naify, 2007.

VELHO, Otávio. Besta-Fera: recriação do mundo. Rio de Janeiro: Relume Dumará, 1995.

VELOSO, Caetano. Verdade Tropical. São Paulo: Companhia das Letras, 1997.

VILELA, Ivan. Nada Ficou Como Antes. Revista USP, v. 87, p. 14-27, 2010.

VIVEIROS DE CASTRO, Eduardo. O Nativo Relativo. Mana, vol.8, $\mathrm{n}^{\circ}$ 1. Rio de Janeiro: Abril de 2002.

ZUMTHOR, Paul. Performance, recepção, leitura. São Paulo, Cosac Naify, 2007.

Sites

Museu Clube da Esquina: http://www.museuclubedaesquina.org.br/.

Nat Geo:

http://worldmusic.nationalgeographic.com/view/page.basic/genre/content.genre/n ueva_cancion_762/en_US.

\author{
Álbuns \\ Clube da Esquina, 1972. \\ Clube da Esquina 2, 1978. \\ Milton, 1970.
}

\title{
Periódicos
}

Jornal do Brasil.

O Globo.

O Estado de Minas.

Revista Bizz. 


\section{Anexos}

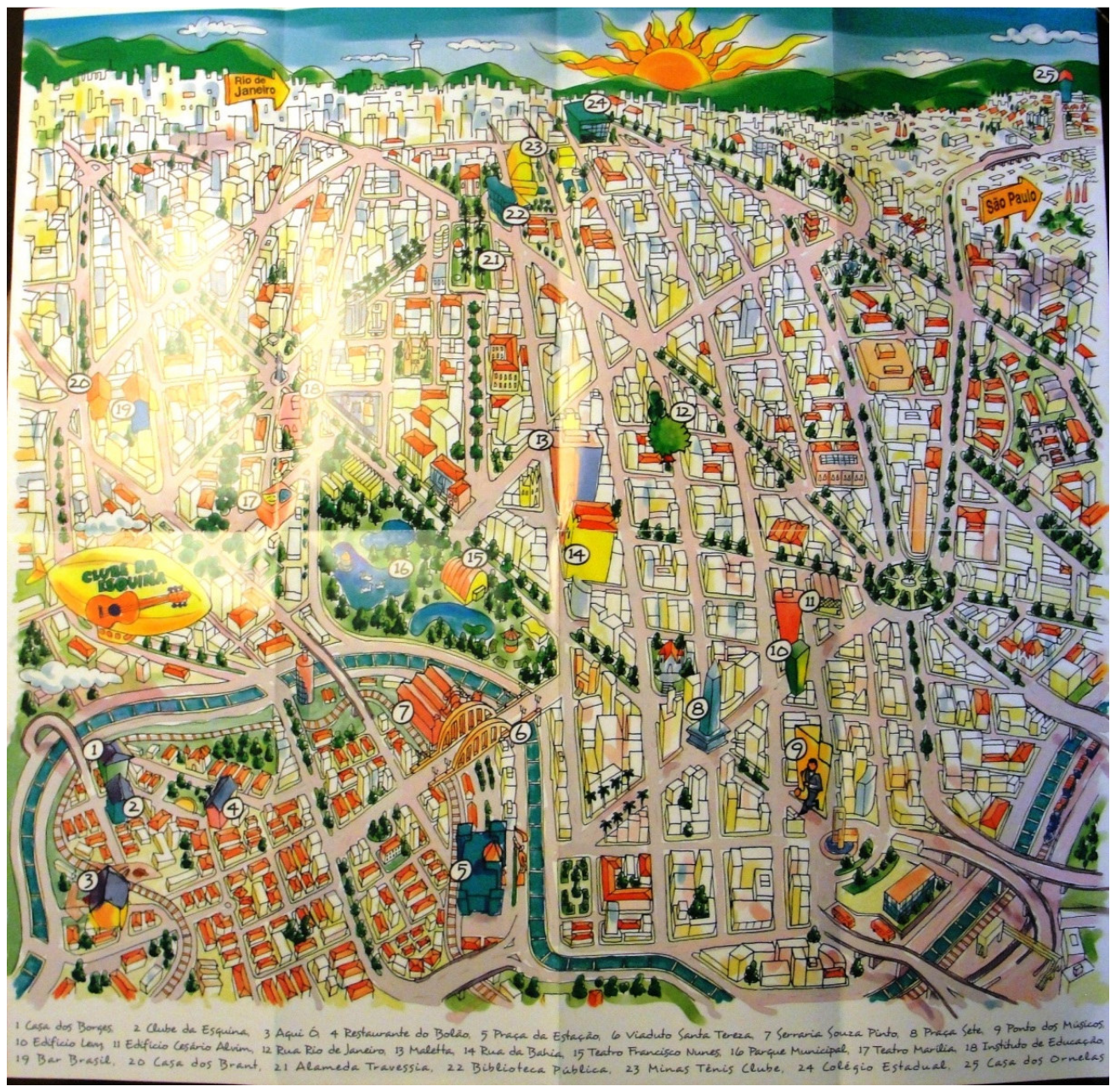

Mapa do Guia de Belo Horizonte: Roteiro Clube da Esquina indicando os locais em que foram colocadas placas do Museu do Clube da Esquina.

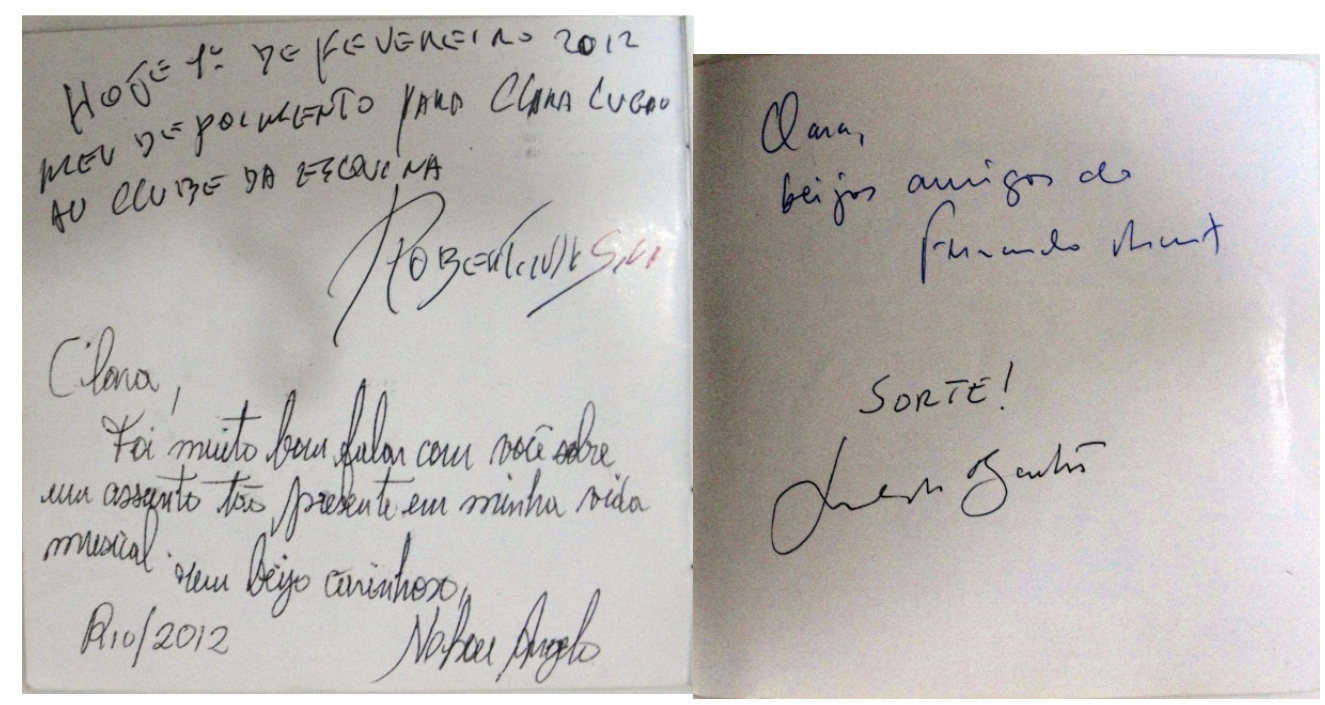



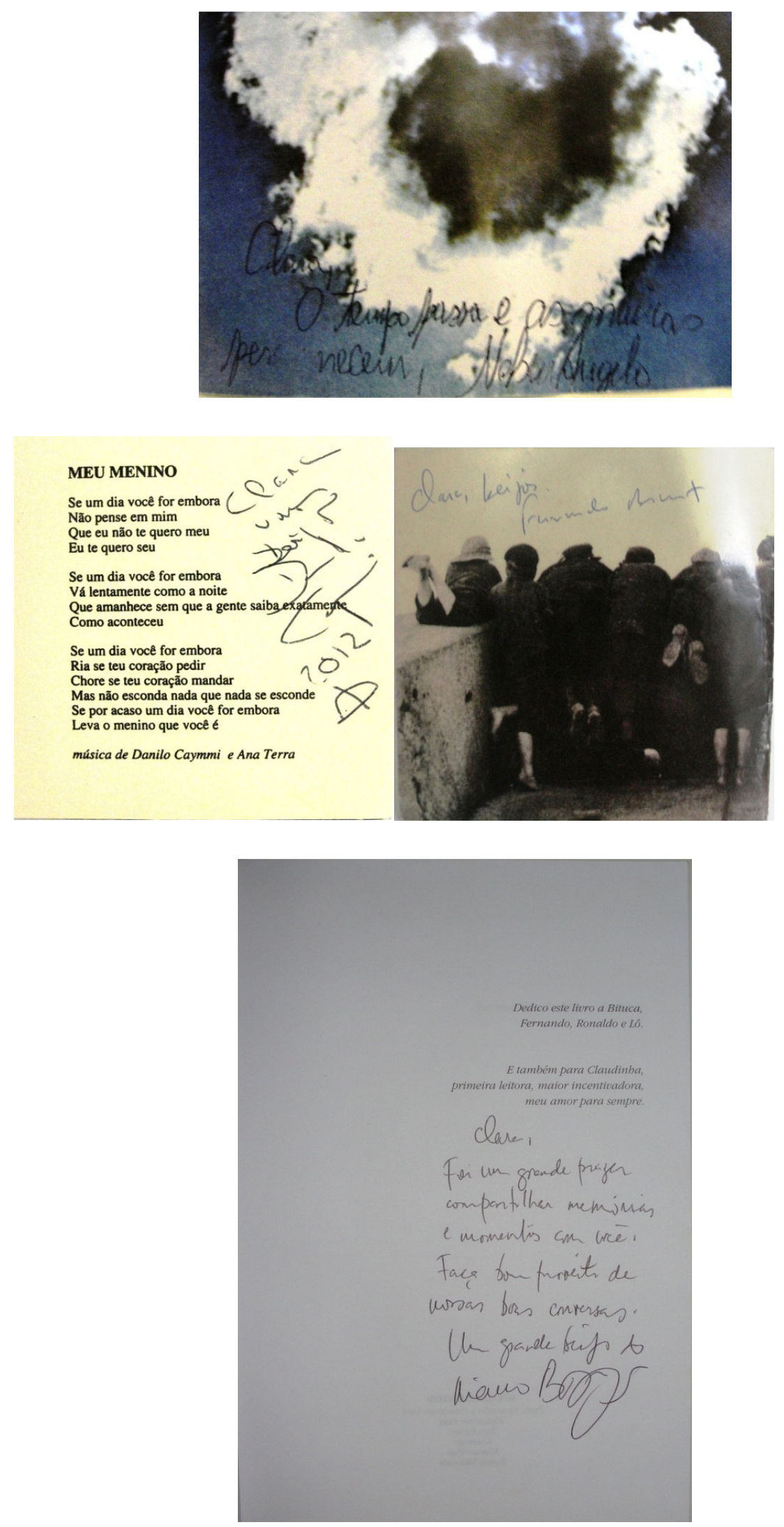

Registros das entrevistas feitas com os músicos do Clube da Esquina 